Prepared for the U.S. Department of Energy

under Contract DE-AC05-76RL01830

\title{
The Effects of Fire on the Function of the 200-BP-1 Engineered Surface Barrier
}

\author{
$\mathrm{AL} \mathrm{Ward}^{(\mathrm{a})}$ \\ $\mathrm{NHasan}^{(\mathrm{a})}$ \\ SO Link ${ }^{(b)}$ \\ KE Draper ${ }^{(a)}$ \\ (a) Pacific Northwest National Laboratory \\ (b) Native Plant Landscaping and Restoration, West Richland, WA
}

September 2009

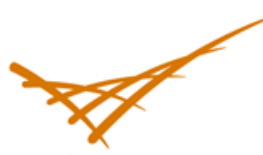

Pacific Northwest

NATIONAL LABORATORY

Proudly Operated by Battelle Since 1965 


\title{
DISCLAIMER
}

This report was prepared as an account of work sponsored by an agency of the United States Government. Neither the United States Government nor any agency thereof, nor Battelle Memorial Institute, nor any of their employees, makes any warranty, express or implied, or assumes any legal liability or responsibility for the accuracy, completeness, or usefulness of any information, apparatus, product, or process disclosed, or represents that its use would not infringe privately owned rights. Reference herein to any specific commercial product, process, or service by trade name, trademark, manufacturer, or otherwise does not necessarily constitute or imply its endorsement, recommendation, or favoring by the United States Government or any agency thereof, or Battelle Memorial Institute. The views and opinions of authors expressed herein do not necessarily state or reflect those of the United States Government or any agency thereof.

\author{
PACIFIC NORTHWEST NATIONAL LABORATORY \\ operated by \\ BATTELLE \\ for the \\ UNITED STATES DEPARTMENT OF ENERGY \\ under Contract DE-AC05-76RL01830
}

Printed in the United States of America

Available to DOE and DOE contractors from the

Office of Scientific and Technical Information,

P.O. Box 62, Oak Ridge, TN 37831-0062;

ph: (865) 576-8401

fax: $(865) 576-5728$

email: reports@adonis.osti.gov

\footnotetext{
Available to the public from the National Technical Information Service, U.S. Department of Commerce, 5285 Port Royal Rd., Springfield, VA 22161 ph: (800) 553-6847 fax: $(703) 605-6900$

email: orders@ntis.fedworld.gov

online ordering: http://www.ntis.gov/ordering.htm
}

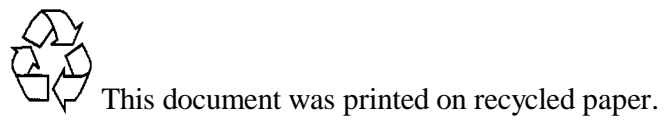




\title{
The Effects of Fire on the Function of the 200-BP-1 Engineered Surface Barrier
}

\author{
$\mathrm{AL} \mathrm{Ward}^{(\mathrm{a})} \quad \mathrm{NHasan}^{(\mathrm{a})}$ \\ SO Link ${ }^{(\mathrm{b})} \quad$ KE Draper $^{(\mathrm{a})}$ \\ (a) Pacific Northwest National Laboratory \\ (b) Washington State University, Richland, WA
}

September 2009

Prepared for

the U.S. Department of Energy

under Contract DE-AC05-76RL01830

Pacific Northwest National Laboratory

Richland, Washington 99352 



\section{Executive Summary}

A critical unknown for long-term engineered barrier performance is the effect of wild fire during a post-institutional control environment where routine maintenance may be limited or non-existent. The objective of this study was to quantify the effects of a wildfire on the function of an engineered barrier. A controlled burn on September 26, 2008, was used to remove all the vegetation from the north side of the prototype Hanford barrier in the 200 East Area. Fire effects on barrier performance have been monitored and documented over the past year. Soil physical, chemical, and hydrologic properties; plant floristics and density; and animal-use were characterized before and after the fire with the unburned half of the barrier serving as a control.

Flame heights exceeded $9 \mathrm{~m}$, and temperatures ranged from $250^{\circ} \mathrm{C}$ at $1.5 \mathrm{~cm}$ below the surface to over $700^{\circ} \mathrm{C}$ at $1 \mathrm{~m}$ above the surface. Post-fire analysis of soil properties shows significant decreases in wettability, hydraulic conductivity, air-entry pressure, organic matter, and porosity relative to pre-fire conditions whereas dry bulk density increased. Decreases in hydraulic conductivity and wettabilty immediately after the fire are implicated in a surface runoff event that occurred in January 2009, the first in 13 years. There was a significant increase in macro-nutrients, $\mathrm{pH}$, and electrical conductivity. After 1 year, hydrophobicity has returned to pre-burn levels with only $16 \%$ of the samples still showing signs of decreased wettability. Over the same period, hydraulic conductivity and air-entry pressure returned to pre-burn levels at one third of the locations but remained identical to values recorded immediately after the fire at the other two thirds. Soil nutrients, $\mathrm{pH}$, and electrical conductivity remain elevated after 1 year. There were significant differences in the rate of accumulation and loss of soil moisture on the burned and unburned sections. On the burned section, water storage was higher during the fall, it increased more slowly with the onset of winter precipitation (owing to higher evaporation), and decreased more slowly in the spring (owing to lower evapotranspiration). Xylem pressure potentials were considerably higher on the burned half of the barrier in September 2009, which is consistent with observed differences in storage and suggest that not all the water in the soil profile will be removed before the fall rains begin. Species composition on the burned surface changed markedly from prior years, and this was relative to the unburned surface and two analog sites. An increase in the proportion of annuals and biennials is characteristic of burned surfaces that have become dominated by ruderal species. Greenhouse seedling emergence tests conducted to assess the seed bank of pre- and post-burn soils and of two analog sites at the McGee Ranch show no difference in the number of species emerging from soils collected before and after the fire. However, there were fewer species emerging from the seed bank on the side slopes and more species emerging from two analog sites. Leaf-area index measurements confirmed the substantial differences in plant communities after the fire.

The results of this study are expected to contribute to a better understanding of barrier performance after major disturbances in a post-institutional control environment. Such an understanding is needed to enhance stakeholder acceptance regarding the long-term efficacy of engineered barriers and to support improvements in barrier design. 



\section{Acronyms and Abbreviations}

$\begin{array}{ll}\text { ALCD } & \text { Alternative Landfill Cover Demonstration } \\ \text { ASTM } & \text { American Society for Testing and Materials } \\ \text { CEC } & \text { Cation Exchange Capacity } \\ \text { CERCLA } & \text { Comprehensive Environmental Response, Compensation, and Liability Act of } 1980 \\ \text { DOE } & \text { U.S. Department of Energy/Richland Operations Office } \\ \text { EAS } & \text { Environmental Assessment Services } \\ \text { EPA } & \text { U.S. Environmental Protection Agency } \\ \text { ET } & \text { Evapotranspiration } \\ \text { HFD } & \text { Hanford Fire Department } \\ \text { LAI } & \text { Leaf Area Index } \\ \text { NRCS } & \text { Natural Resources Conservation Service } \\ \text { NWAg } & \text { Northwest Agricultural Consultants } \\ \text { OU } & \text { Operable Unit } \\ \text { PNNL } & \text { Pacific Northwest National Laboratory } \\ \text { PVC } & \text { polyvinyl chloride } \\ \text { RTD } & \text { Removal, Treatment, and Disposal } \\ \text { USDA } & \text { U.S. Department of Agriculture } \\ \text { WDPT } & \text { Water Drop Penetration Time } \\ \text { XRD } & \text { X-Ray Diffraction }\end{array}$





\section{Contents}

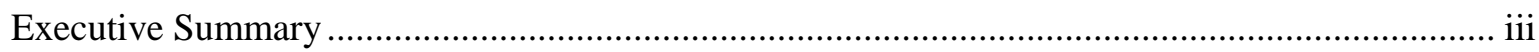

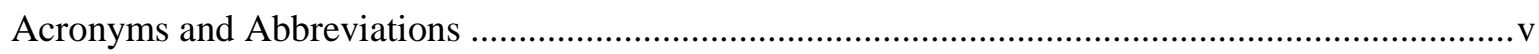

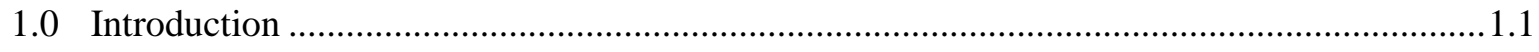

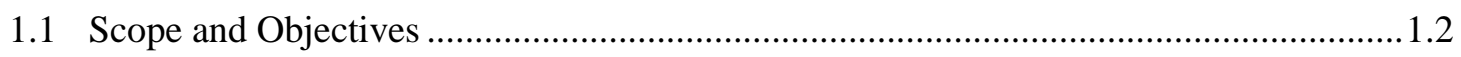

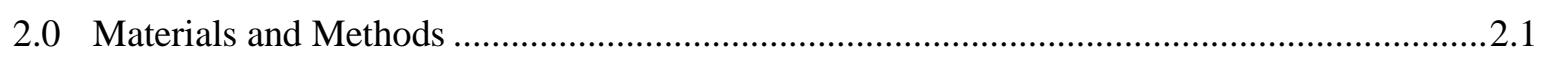

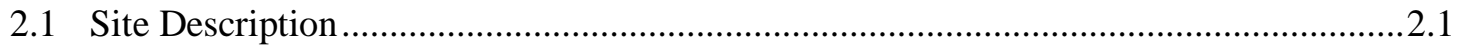

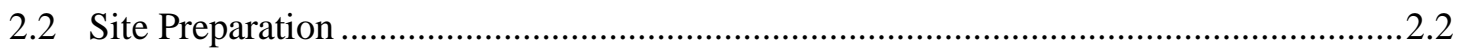

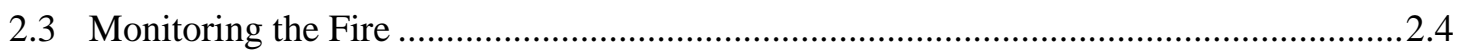

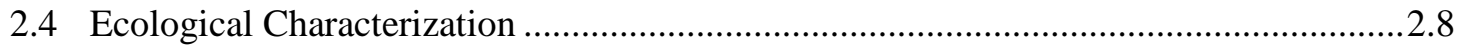

2.4.1 Fuel-Load Characterization and Modification ..................................................2.8

2.4.2 Plant Root Distributions .......................................................................... 2.10

2.4.3 Plant Species Composition ............................................................................. 2.11

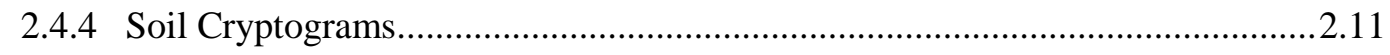

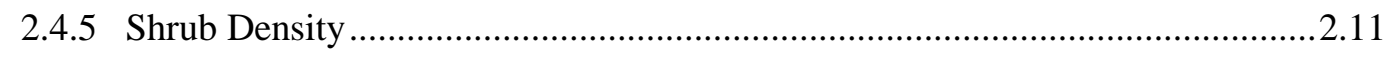

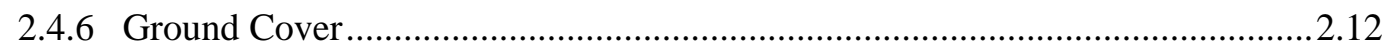

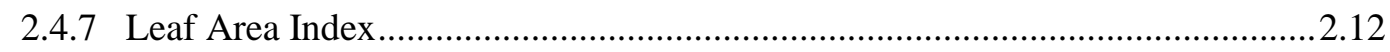

2.4.8 Plant Water Status ....................................................................................... 2.13

2.4.9 Post-Burn Biological Activity and Soil Carbon Dioxide Flux ............................2.13

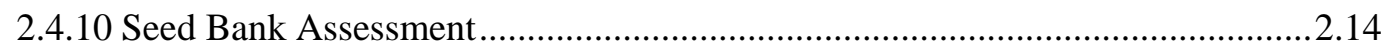

2.4.11 Small Mammal Habitat and Barrier Use ........................................................2.15

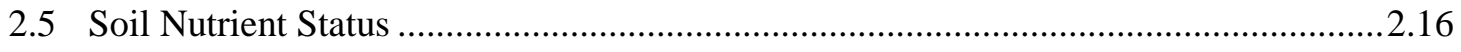

2.6 Characterization of Soil Hydrophysical Properties ........................................................19

2.6.1 Surface-Layer Composition and Inflation/Deflation..........................................2.19

2.6.2 Characterization of Hydraulic Properties ...........................................................2.20

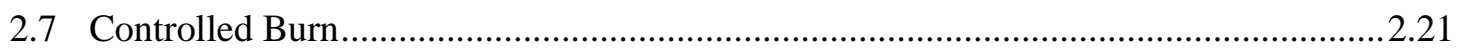

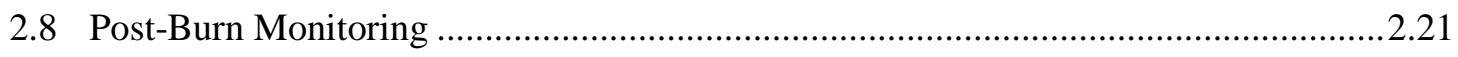

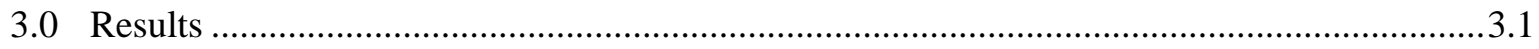

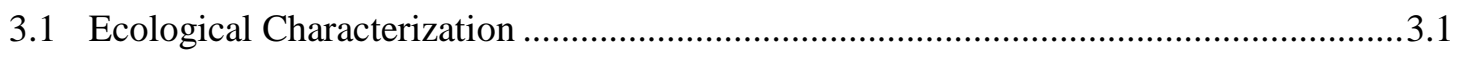

3.1.1 Pre-burn Plant Species Composition .............................................................. 3.1

3.1.2 Post-Burn Plant Species Composition....................................................................3.3

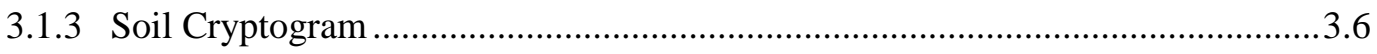

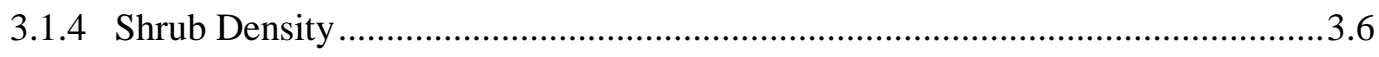

3.1.5 Ground Cover ...............................................................................................

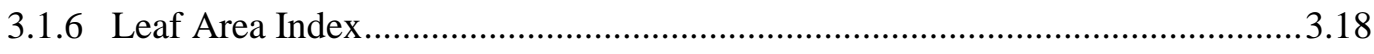

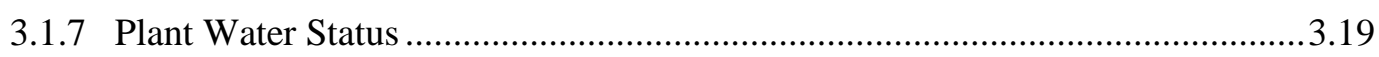

3.1.8 Biological Activity and Soil Carbon Dioxide Flux …........................................2.20 


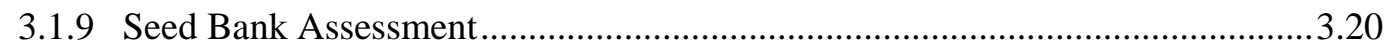

3.1.10 Small Mammal Habitat and Barrier Use ............................................................2.22

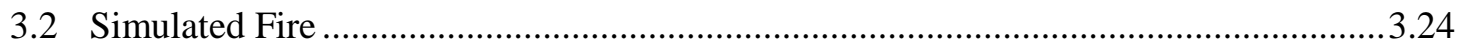

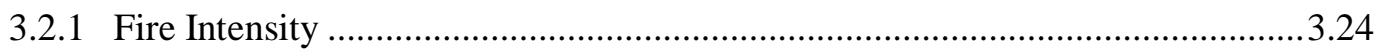

3.3 Surface Layer Composition and Inflation/Deflation ......................................................3.34

3.4 Fire Effects on Soil Water Repellency ............................................................................3.3

3.5 Fire Effects on Hydraulic Conductivity ……................................................................ 3.8

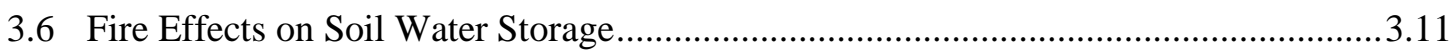

3.7 Fire Effects on Soil Nutrient Status..............................................................................12

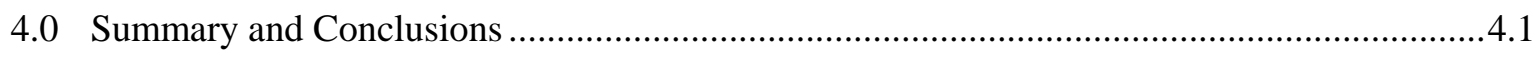

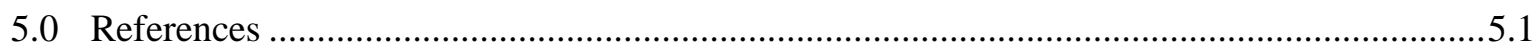




\section{Figures}

2.1. Schematic of a Vegetated, Multilayered Capillary Barrier Showing the Layer Sequence. This cross section includes the rip rap side slope on the eastern side.

2.2. South Facing Aerial View of the Barrier Showing Distribution of Plants on the Surface and Side Slopes Photographed on September 20, 2008.

2.3. Photographs of the Barrier Surface and Gravel Side Slope Showing Examples of Monitoring Infrastructure on the Surface that needed Protection during the Simulated Fire: (a) instrument boxes containing dataloggers and (b) conduits carrying communication cables for instruments........ 2.3

2.4. Preparation of the Barrier for the Controlled Burn: (a) entry points of conduit into instrument boxes covered with soil, (b) instrument box covered with fire shelter, (c) HOBO data loggers for temperature monitoring in waterproof bag before covering with soil and fire shelter, and (d) soil mound covering the HOBO dataloggers prior to being covered with a fire shelter. ................... 2.4

2.5. Inverted Galvanized Pail Used to Cover Minirhizotron Tubes. Tubes were first wrapped in fiberglass insulation.

2.6. Schematic Plan View of the Barrier's Surface Showing Monitoring Stations, the Runoff Plot, the $3 \times 3$ M Grid, and the Nine (1 through 9) $12 \times 12$ m Plots to be Used for Comparing Effects of Fuel Loads on Fire Intensity ................................................................................................. 2.6

2.7. Photograph of Fire Pole Used to Measure Flame Characteristics and to Secure Thermocouples 2.7

2.8. Thermocouples for Measuring Soil and Air Temperature Installed on Flame Height Scaffold: (a) Thermocouples Were Installed $1.5 \mathrm{~cm}$ Deep, at the Surface $(0 \mathrm{~cm}), 1 \mathrm{~cm}, 10 \mathrm{~cm}$, and $30 \mathrm{~cm}$, and (b) Above-Ground Thermistors Were Installed at $100 \mathrm{~cm}$, and $200 \mathrm{~cm}$.

2.9. Photographs of the Barrier's Surface: (a) Sparse vegetation on the surface suggesting need for increased fuel load to emulate realistic conditions. Some Salsola kali (tumbleweed) was already logged among sagebrush plants, and (b) the rip rap side slope of the barrier shows an accumulation of tumbleweed. Dead sagebrush and tumbleweed were imported to the barrier surface to increase the fuel load.

2.10. Unloading of Tumbleweed Brought to the Barrier to Increase Fuel Load. Over 2 tonnes of tumbleweed were added to the surface.

2.11. Redistribution of Imported Tumbleweed Across the Barrier to Achieve Different Fuel Loads for the Controlled Burn. In this photograph, Captain Jerry Keeline of the Hanford Fire Patrol is shown redistributing tumbleweed with a rake.

2.12. Static Diffusion Chamber with Sensors and Readout Device.................................................. 2.13

2.13. Plan View of the Barrier's Surface Showing Proposed Burn Area on the Gravel Side Slope and Silt-Loam Surface.

2.14. Hanford Fire Department Bush Rig Crew Making Adjustments to the Fire Retardant Foam Quality Before the Burn

2.15. The 3-m-Wide Line of Fire Retardant Foam Applied to the Buffer Strip Between the North and South Sections of the Barrier.

2.16. Personnel of the Hanford Fire Department Preparing Drip Torches Before Igniting the Test Plots2.25

3.1. Species Richness on the Entire Barrier Surface Since 1995.

3.2. Temporal Variation in the Number of Species on the Prototype Hanford Barrier from Inception Through September 2009, 1 Year After the Fire. 
3.3. Mean Height of Sagebrush Plants in Quadrats from the South Side of the Burn Area to the North Side.

3.4. Mean Cover on Formerly Irrigated (North) Half of the Barrier Before the Fire. Error bars of one

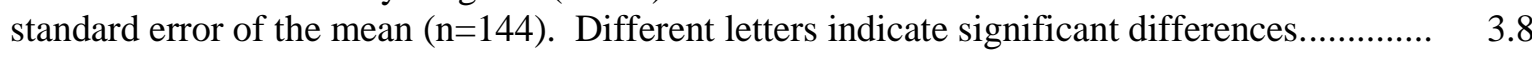

3.5. Cover of Existing Fuel Before Adding Imported Salsola Kali to the Barrier Surface.................. 3.9

3.6. Unburned Section of Barrier Dominated by Artemisia tridentata in 2009, 15 Years After Establishment

3.7. Vegetative Cover on the Burned Half of the Barrier Surface 11 Months After the Fire. Most of the Green Vegetation is Salsola kali.

3.8. Unburned Mature Plant Community at the McGee Ranch Site .........................................3.12

3.9. Old Burned Plant Community at the McGee Ranch Site......................................................... 3.12

3.10. Mean Cover on the North and West Side Slopes of the Barrier. Error bars of one standard error of the mean $(\mathrm{n}=24)$. Different letters indicate significant differences. ...................................... 3.18

3.11. Pre-Burn LAI Across the Barrier Surface ......................................................................... 3.19

3.12. South Facing Aerial View of the Barrier on September 30, 2009 Showing the Burnt North Section and Unburned South Section One Year............................................................................... 3.25

3.13. Ground Fire Crew from the Hanford Fire Department Preparing to Ignite Test Plots .............. 3.26

3.14. Ignition of the Test Plots by the Crew from the Hanford Fire Department. The Fire was Ignited at 3:15 PM September 26, 2008. ................................................................................... 3.27

3.15. Rabbit Brush Near Edge of Barrier Engulfed in Flames Shortly After Ignition....................... 3.28

3.16. A View of the Fire from Southwestern Edge of the Plot About 4 Minutes after Ignition. The Photograph was taken from atop of the HFD Bush Rig. .......................................................... 3.28

3.17. Painted Fire Pole in Foreground Showing a Thermocouple Mounted Perpendicular to the Pole at a Height of $2 \mathrm{~m}$

3.18. Fire or Scorch Intensity Mapped Across the Burned Area. The $X$ and $Y$ edges denote positions on the surface. The distance between coordinate values is 3 meters............................................ 3.29

3.19. Temperature in the Air and Soil Before, During, and After the Fire ..................................... 3.30

3.20. Relationship Between Mean Maximum Temperature and Height from about $1.5 \mathrm{~cm}$ Below Ground to $200 \mathrm{~cm}$ Above the Ground. Error bars are one standard error of the mean......................... 3.31

3.21. Duration of Elevated Temperature. Bars are one standard error of the mean........................... 3.31

3.22. Peak Temperatures Observed on the Burnt Section of the Barrier: (a) Air Temperature Measured $100 \mathrm{~cm}$ Above the Surface and (b) Soil Temperature Measured $1.5 \mathrm{~cm}$ Below the Surface on the Burn Area. Unit is degree Celsius.

3.23. Surface of the Barrier at the End of the Fire. The fire lasted about 7 minutes........................... 3.33

3.24. Surface of the Barrier at the End of the Fire Showing Sporadic White Ash Crust .................... 3.33

3.25. North Section of the Gravel Side Slope Under Fire. The sparse canopy and high moisture of the shrubs resulted in a very spotty burn.

3.26. Distribution of Gravel from 0 to $2 \mathrm{~cm}$ Deep on Burnt Section: (a) Pre-Burn Gravel Content and (b) Difference Between Pre- and Post-Burn Content................................................................. 3.34

3.27. Distribution of Gravel from 0 to $2 \mathrm{~cm}$ Deep on Burnt Section: (a) Pre-Burn Gravel Content and (b) Difference Between Pre- and Post-Burn Content..................................................................

3.28. Soil Deposition Patterns on a Snow-Covered Surface on December 16, 2008......................... 3.1 
3.29. Soil Inflation and Deflation Patterns on the Burned Area. The X and Y edges denote positions on the surface. The distance between coordinate values is 3 meters

3.30. Distribution of Dry Bulk Density on Burnt Section: (a) Pre-Burn Bulk Density and (b) Difference Between Pre- and Post-Burn Density .................................................................................

3.31. Photograph of Burned Surface During Water Drop Penetration Test....................................... 3.4

3.32. Relationship Between Infiltration Rate from a Mini-Disk Infiltrometer and Water Drop Penetration Tests.

3.33. Comparison of In-Situ Pre-Burn and Post-Burn Estimates of the Hydraulic Conductivity ....... 3.10

3.34. Comparison of In Situ Pre-Burn and Post-Burn Estimates of the Alpha Parameter.................. 3.11

3.35. Post-fire Average Water Storage at the Barrier, (a) North Plots, (b) South Plots, (c) Northwest and Southwest Plots, and (d) Northeast and Southeast Plots. 


\section{Tables}

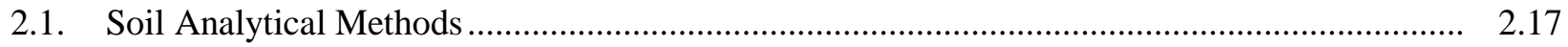

2.2. Method Detection Limits for Soil Nutrient Analyses........................................................ 2.18

3.1. Plant Species Observed in 2009 on the Burned and Unburned Sections of the Barrier Plus at two McGee Ranch Analog Sites....................................................................................

3.2. Plant Species Observed in 2009 on the West and North Side-Slopes of the Barrier................. 3.5

3.3. Lichens and Mosses on the Barrier and at the Burned and Unburned McGee Ranch............... 3.7

3.4. Mean Shrub Density (plants $\left.\mathrm{m}^{-2}\right) \pm 1$ Standard Error of the Mean.......................................... 3.9

3.5. Mean size/age Density (plants $\mathrm{m}^{-2}$ ) \pm 1 Standard Error of the Mean of A. Tridentata at the Four Study Sites............................................................................................................ 3.9

3.6. Median, Mode, and Mean Percent Cover Classes Ranges for Grass....................................... 3.13

3.7. Median, Mode, and Mean Percent Cover Classes Ranges for Shrubs..................................... 3.14

3.8. Median, Mode, and Mean Percent Cover Classes Ranges for Litter ........................................ 3.15

3.9. Median, Mode, and Mean Percent Cover Classes Ranges for Bare Ground............................ 3.16

3.10. Cover of Plant Species and Other Categories Observed in 2009 on the Burned and Unburned Sections of the Barrier and Two McGee Ranch Analog Sites................................ 3.17

3.11. Mean Soil Respiration Rates \pm 1 Standard Error of the Mean $\left(\mu \mathrm{mol} \mathrm{CO} \mathrm{CO}_{2} \mathrm{~m}^{-2} \mathrm{~s}^{-1}\right) \ldots \ldots \ldots \ldots \ldots \ldots . . . . . . .20$

3.12. Species Emerging from the Seed Bank on the Burned and Unburned Sections of the Barrier, the Side-slope, and at the two McGee Ranch Analog Sites

3.13. Mean Seedling Density ( \pm 1 standard error of the mean) from the Seed Bank at Five Study Sites

3.14. Mean Seedling Density ( \pm 1 standard error of the mean) from the Seed Bank Under Six Conditions at the two McGee Ranch Analog Sites ( $b$ = old burn, $\mathrm{u}=$ unburned)...

3.15. Effect of Fire on Soil Water Repellency Measured in the Laboratory ...................................... 3.5

3.16. Soil Water Repellency Measured in the Laboratory 4 Months After the Fire.......................... 3.6

3.17. Soil Water Repellency Measured in the Laboratory 1 Year After the Fire .............................. 3.7

3.18. Effect of Fire on Soil Physical and Hydraulic Properties After Fire ..................................... 3.10

3.19. Effect of Fire on Immediate Post-Burn Soil Nutrient Status ................................................. 3.13

3.20. Effect of Fire on Post-Burn Soil Nutrient Status 1 Year after Burn ......................................... 3.14 


\subsection{Introduction}

Engineered surface barriers are now recognized as a remedial alternative to the removal, treatment, and disposal (RTD) of near-surface contaminants at a variety of waste sites within the U.S. Department of Energy (DOE) complex. The primary function of engineered barriers is to control infiltration of meteoric water through the surface. This function is typically accomplished through a water storage and release mechanism in which water is stored in fine-textured soils during the rainy season and recycled to the atmosphere by evapotranspiration. The resulting reduction in infiltration eliminates the major driving force for transporting mobile contaminants through the vadose zone to the water table. Most engineered barriers consist of one or more, but not necessarily all, of the following: 1) a surface layer, 2) a protection layer, 3) a drainage layer, 4) a barrier layer, and 5) a gas-collection or foundation layer (Daniel 1994; EPA 1989). Typically, the surface layer serves as a root medium to support vegetation that is used to recycle water to the atmosphere.

Over the functional life of an engineered barrier, the barrier will be subjected to extreme events including abnormal precipitation events. In a worst-case scenario, an extreme precipitation event would occur on a bare surface (no vegetation), a condition that could result from a wildfire. Thus, understanding how an engineered barrier responds and ultimately recovers from such major disturbances is important in predicting performance. Accurate predictions are an important component in obtaining public and regulatory acceptance of barriers as an effective remedial technology.

The hydrology of barriers under extreme precipitation events is well documented at Hanford and other sites. In 1994, a multilayered capillary barrier was constructed over the B-57 crib in Hanford's 200 East Area to collect performance data for field-scale engineered barriers. A 3-yr Comprehensive Environmental Response, Compensation, and Liability Act (CERCLA) treatability test successfully demonstrated barrier constructability and hydrologic performance beyond design requirements even when exposed to three simulated 1000-yr return storm events, one each year of the test (DOE-RL 1999). The Alternative Landfill Cover Demonstration (ALCD) also tested new designs with currently accepted U.S. Environmental Protection Agency (EPA) cover designs as baselines (Dwyer et al. 2000). Covers were installed and instrumented in a side-by-side demonstration that included tests under ambient and "stressed" conditions imposed by a rain simulation system. Both datasets show that storage and release covers can exceed established performance criteria when adequately designed and constructed.

The resulting data have proven useful in developing more rigorous methods for evaluating long-term performance and quantifying associated risk and uncertainty (White and Ward 2005; Ward et al. 2006) but are relatively short-term. Many of the waste sites to be remediated by barriers contain long-lived contaminants, and rigorous evaluation of performance must consider long-term changes that may result from major disturbances like floods and wildfire and degradation. The degradation of engineered barriers is a complex process controlled by the interplay of physical and biological factors, including climate, hydrologic properties of soil components, and the spatial and temporal characteristics of the vegetation and wildlife on the barrier. Designing reliable barriers and accounting for disturbance and degradation implies an ability to evaluate performance over the design life before actual construction. Such evaluations are commonly performed with numerical models with the typical assumption of timeinvariant soil properties and climax plant communities. Post-construction soil conditions can be expected to change as structure develops, so invariant soil properties cannot be justified. Similarly, the assumption of climax communities as a management tool has often been criticized (e.g., Pendleton 1989, Friedel 
1991, Tausch et al. 1993, Borman and David 1994). This is because of 1) the difficulty in determining the climax vegetation for artificially vegetated engineered covers and 2) replacement of the "climax" community by some other stable community other than the climax, i.e., disclimax plant associations after major disturbances such as fire. None of the existing models can accurately simulate the structure and dynamics of the plant communities or the climax community, nor the disclimax associations that may return after disturbance by wildfire. Thus, an important step in gaining regulatory acceptance is demonstrating the impact of short- and long-term impacts of major disturbance on barrier performance, including the structure and dynamics of plant communities.

Although there have been no published studies of the effect of wildland fire on the performance of engineered covers, a considerable amount of research has been conducted on effects of fire on the flora, fauna, atmosphere, and soil in natural ecosystems (Doerr and Cerdà 2005). The studies show that the effects of fire on natural ecosystems are quite complex and may range from the reduction, or even elimination, of above-ground biomass to impacts on soil physical, chemical, and microbial mediated processes (FEIS 2008). Wildfire and the resulting post-fire conditions can alter soil physical properties (soil aggregate stability, water repellency, and runoff response) and geochemical properties (e.g., mineralogy, $\mathrm{pH}$, and nutrient availability) as well as fundamental ecological processes (e.g., biomass productivity, vegetative re-sprouting, plant species recruitment, microbial composition, and animal habitat). The damage sustained by plants has been shown to be proportional to the intensity and duration of the fire that affects the growing points. An immediate effect is the destruction of surface litter and vegetation that is important in protecting the soil from raindrop impact, a necessity for reducing runoff (Powers et al. 1990, Neary et al. 1999). Runoff can also be enhanced by fire-induced water repellency that develops at the soil surface because of the coating of soil aggregates with hydrophobic organic compounds (DeBano 1981). Surface runoff increases the losses of nutrients, fine-textured sediments, and moisture.

In engineered ecosystems where nutrients may be already limiting, soil and nutrient loss could inhibit ecological processes necessary for successful barrier performance. Owing to the strong coupling of the physical, chemical, and ecological effects, fire-induced alterations are site-specific and cannot be easily extrapolated to other locations, particularly engineered ecosystems. It is therefore important that data on the key physical, chemical, and biological processes controlling barrier ecosystem performance and sustainability be documented. To answer outstanding questions on long-term performance and monitoring, a prescribed burn simulating a wildfire was conducted during the fall of 2008 at the prototype Hanford barrier in Hanford's 200 East Area.

\subsection{Scope and Objectives}

The scope of the study was to evaluate the short- and long-term impacts of a simulated wildfire on soil hydrophysical and geochemical properties as well as the ecological processes controlling barrier performance (Ward et al. 2008; Ward et al. 2009). There were three main objectives to this study:

1. Characterize barrier conditions before the fire and evaluate preventative measures for protecting barrier monitoring instrumentation against fire damage.

2. Document fire effects on soil physical (e.g., infiltration capacity, macro-porosity, aggregate stability, water repellency, wind and water erosion) and geochemical (e.g., mineralogy, $\mathrm{pH}$, nutrient availability, and C:N ratios) properties. 
3. Document fire effects on ecological processes such as evapotranspiration, biomass productivity, plant and animal use, and post-fire colonization by plants, including the rate of re-establishment of vegetation.

Immediate post-burn monitoring focused on quantifying alterations in the soil's physical and geochemical characteristics, recovery of the plant cover, and animal use. Barrier responses to the simulated fire are being documented to allow inferences about fire behavior under different fuel loadings and fire intensities. 


\subsection{Materials and Methods}

The study to assess the effects of fire on barrier performance was conducted at the 200-BP-1 prototype Hanford barrier in the 200 East Area. The barrier was constructed in 1994 over and to the north of the 216-B-57 waste crib in the former 200-BP-1 (now known as the 200-PW-5) Operable Unit (DOE 1999). This operable unit (OU) is located in the 200 East Area of the Hanford Site in the B-BX-BY complex, northwest of the BY tank farm, north of the B-trenches, and southwest of the BY cribs (Ward et al. 2008).

\subsection{Site Description}

The barrier is vegetated and multilayered, which is based on the capillary break concept (Figure 2.1). A layer of coarse material is placed directly below finer textured soil. The fine-soil layer acts as a medium in which moisture is stored until the processes of evaporation (E) and plant transpiration (T) can recycle any excess water back to the atmosphere. In other words, the top $2 \mathrm{~m}$ of silt loam functions as an evapotranspiration (ET) barrier. The fine-soil layer also provides a rooting medium to support plants that are necessary for transpiration to take place. The gravel admix comprising the surface reduces erosion due to wind and water. The coarser materials that are placed directly below the fine soil layers prevent the finer soils from filtering into the coarser materials and create a capillary break that inhibits the downward percolation of water through the barrier. The basalt riprap sequence controls bio-intrusion by discouraging burrowing animals and creating a low moisture layer to mitigate or prevent root penetration. A low-permeability asphalt layer, placed in the barrier profile below the capillary break and the biointrusion layers, diverts any water that passes the capillary break away from the waste zone and limits the upward movement of noxious gases from the waste zone. Figure 2.2 shows a south-facing aerial view of the barrier in September 2008, before the controlled burn.

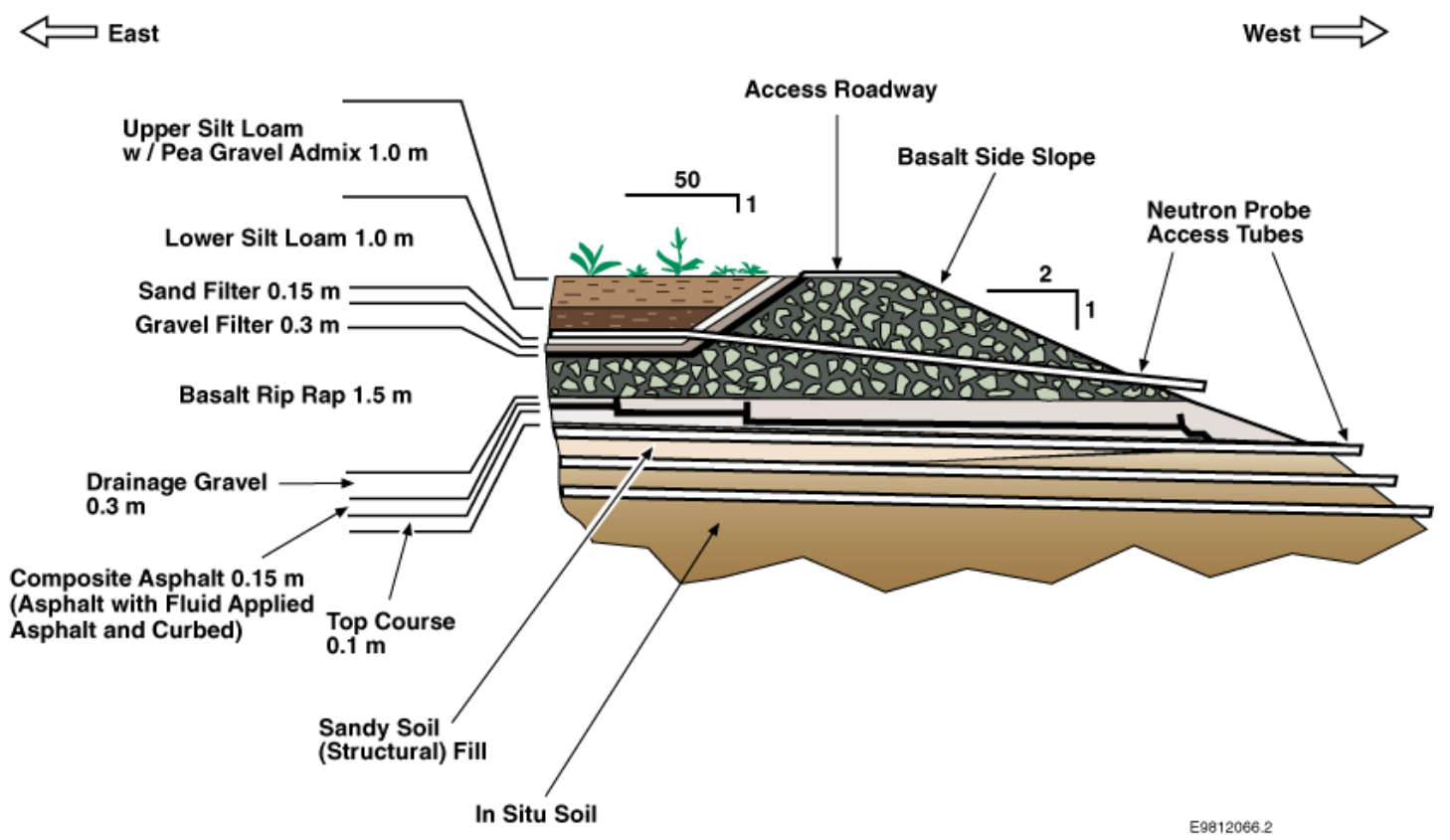

Figure 2.1. Schematic of a Vegetated, Multilayered Capillary Barrier Showing the Layer Sequence. This cross section includes the rip rap side slope on the eastern side. 


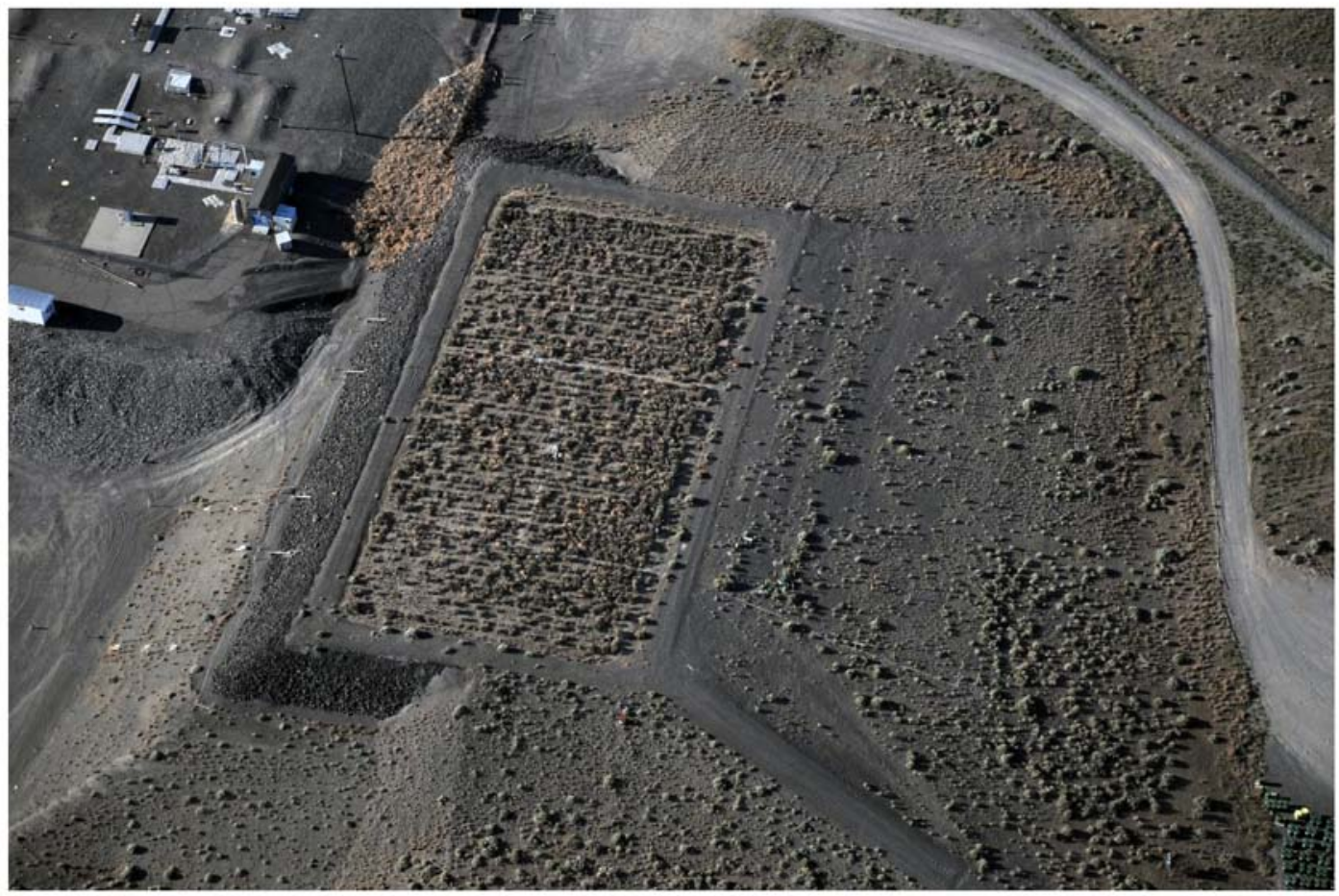

Figure 2.2. South Facing Aerial View of the Barrier Showing Distribution of Plants on the Surface and Side Slopes Photographed on September 20, 2008.

During construction in 1994, the top $1 \mathrm{~m}$ of silt loam was amended by adding $15 \%$ by weight of pea gravel. The gravel was added to minimize wind and water erosion of the silt loam soil immediately after construction, when the surface was bare, and during periods of drought, wildfire, or any other period of increased eolian or aqueous stresses. The north half was expected to show larger gravel contents than the south half because the north was exposed to more water initially from irrigation, which apparently removed or compacted surface silt to result in a higher gravel content in the near surface.

\subsection{Site Preparation}

Although one of the original objectives of the testing program at the prototype barrier was to investigate monitoring technologies and establish a cost basis for long-term monitoring, not much consideration was given to fire protection during the installation of instruments. Thus, preparing for the simulated fire included preparing the monitoring installations for the anticipated temperature increases. Instruments from the monitoring stations are connected to data loggers housed in two large polyethylene boxes, as shown in Figure 2.3a. A site walk down with the fire crew before the test also identified a number of cables on the surface in polyvinyl chloride (PVC) conduit (Figure 2.3b). During installation, none of the instrument boxes housing electronics were mounted flush with the surface. This was intentional to prevent water or snowmelt from running into the boxes and damaging the instruments. Consequently, most of the cables and conduits used for the cables on the barrier surface and side slopes were exposed near the entry point to the boxes. 
(a)

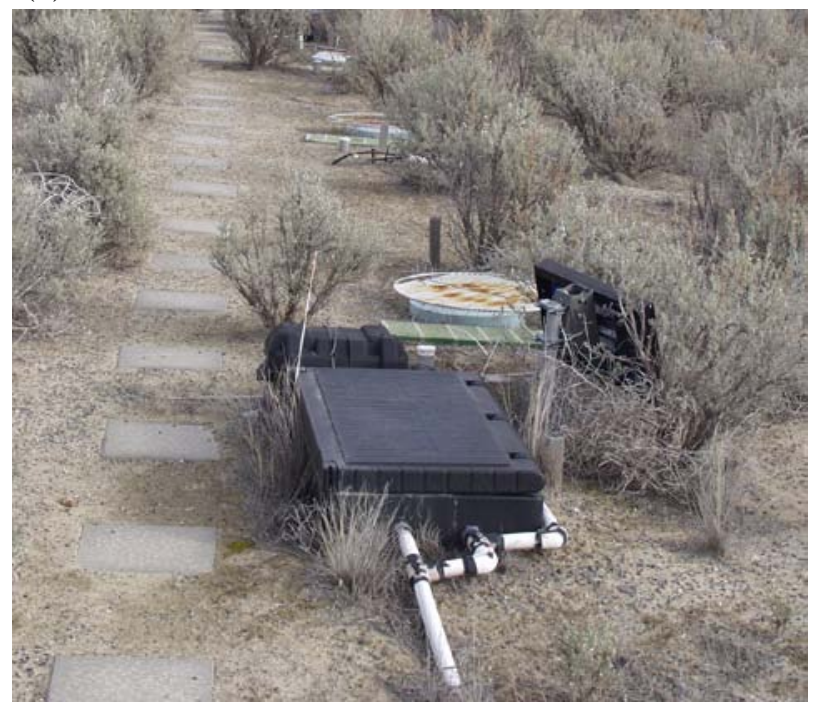

(b)

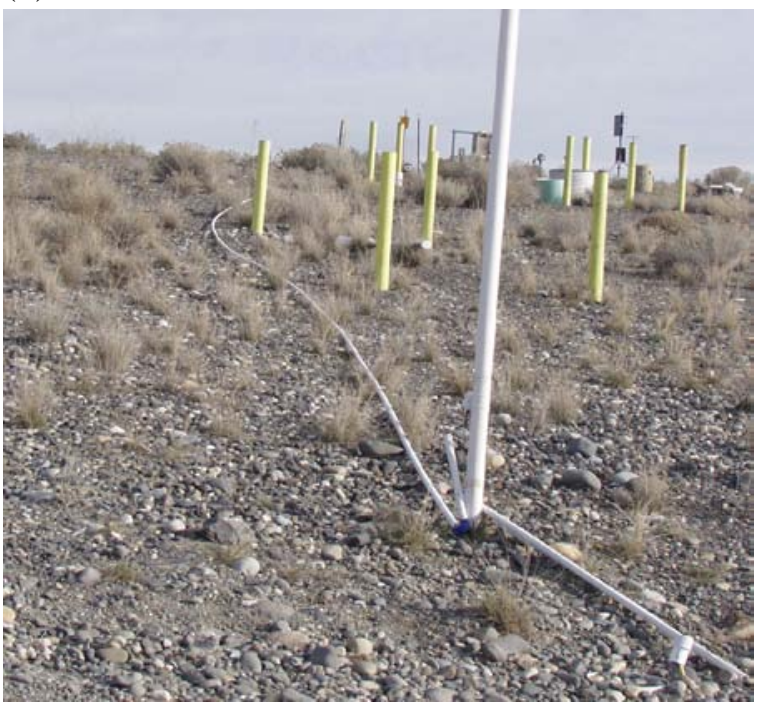

Figure 2.3. Photographs of the Barrier Surface and Gravel Side Slope Showing Examples of Monitoring Infrastructure on the Surface that needed Protection during the Simulated Fire:

(a) instrument boxes containing dataloggers and (b) conduits carrying communication cables for instruments.

Preparing for the simulated fire therefore included burying the conduits and cables and protecting the instrument boxes and other surface installations. Instrument boxes were packed with fiberglass insulation and properly closed. Exposed conduits and cables were buried by trenching, where soil disturbance could be tolerated, or covered with an appropriate layer of dry soil (Figure 2.4a,d) and aluminum fire shelters (Figure 2.4b). Fire blankets and aluminum foil covers were secured around the edges by covering with soil. New instruments on the surface, e.g., HOBO dataloggers for temperature logging, were secured in a waterproof bag (Figure 2.4c) before being covered with dry soil and aluminum fire shelters. Any instrumentation that was not essential for testing or for collecting supporting data was removed. All remaining infrastructure was covered with fire shelters for the duration of fire test. Aluminum and polyvinyl chloride (PVC) subsurface access tubes were covered with soil before fire shelters were emplaced. Six minirhizotrons, constructed of clear acrylic tube with outer PVC sleeves, are present on the north side of the barrier and have been used to measure root distributions. These tubes extend some $30 \mathrm{~cm}$ above the surface, and were at risk for fire damage. Each tube was wrapped with a layer of Fiberglas insulation before covering with an inverted galvanized pail (Figure 2.5). 
(a)

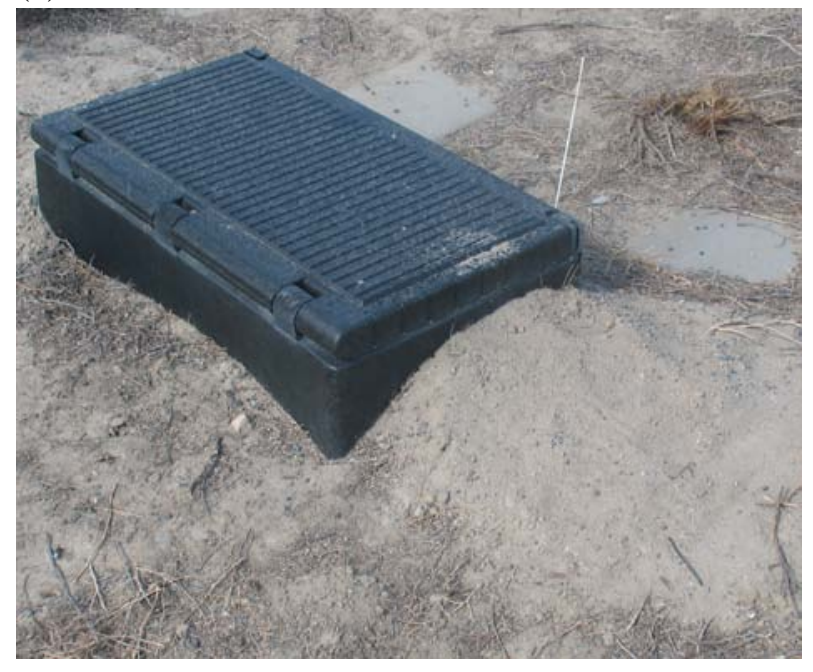

(c)

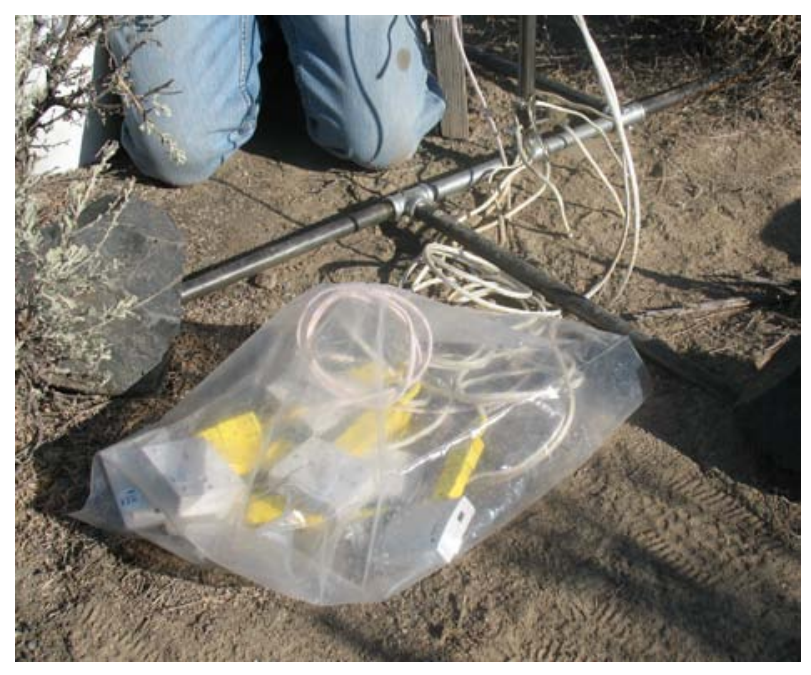

(b)

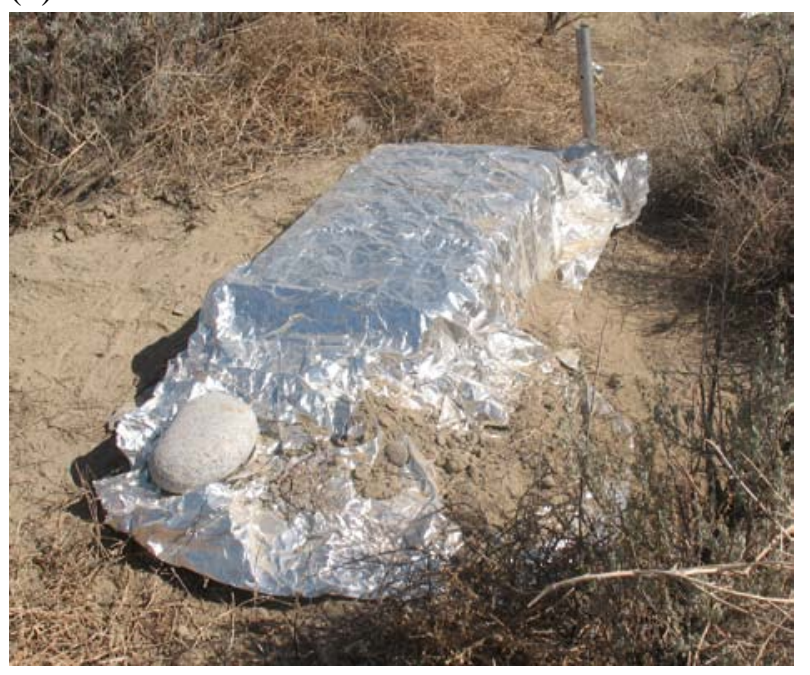

(d)

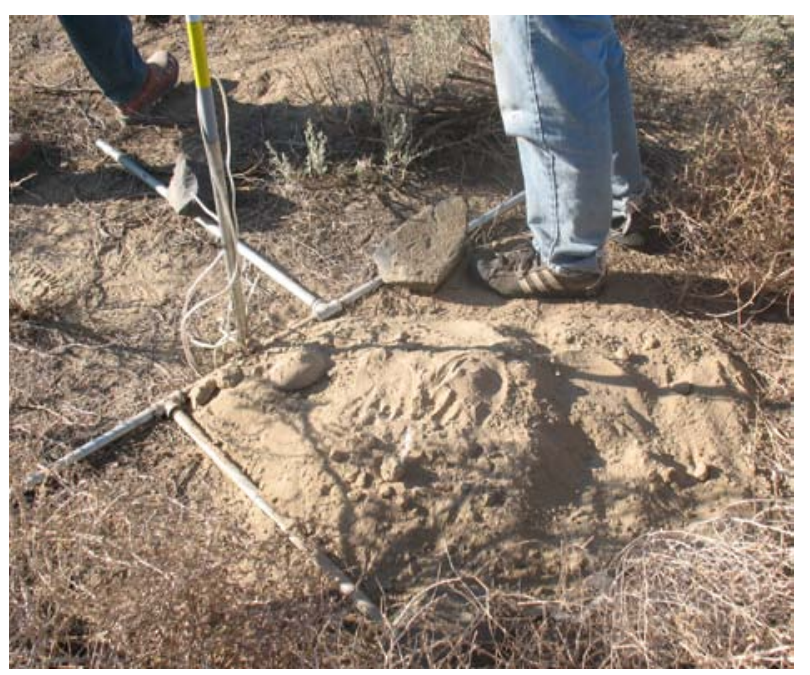

Figure 2.4. Preparation of the Barrier for the Controlled Burn: (a) entry points of conduit into instrument boxes covered with soil, (b) instrument box covered with fire shelter, (c) HOBO data loggers for temperature monitoring in waterproof bag before covering with soil and fire shelter, and (d) soil mound covering the $\mathrm{HOBO}$ dataloggers prior to being covered with a fire shelter.

\subsection{Monitoring the Fire}

Responses to the fire potentially vary according to the intensity of the fire, and the site was configured and instrumented to permit monitoring. The simulated fire was limited to the north half of the barrier, which was divided into nine 12-m × 12-m (39.4-ft × 39.4-ft) plots (Figure 2.6). Nine flameheight poles fitted with thermocouples (Figure 2.7) were installed at the center of each plot for visual observation of flame height and to quantify fire intensity during the course of the fire. Flame height is used to estimate radiation intensity of flames, which is directly related the rate of spread of a fire (Johnson 
and Miyanishi 2001). Two theoretical definitions of flame height are commonly used, 1) the height where flames reach the maximum temperature and 2) the vertical distance from the flame base or ground to the time-averaged yellow flame tip (Johnson and Miyanishi 2001). The progress of the fire was documented using a video camera configured to view the entire burn area. During the fire, the scorch height was measured by recording the elevation of the scorch marks on flame-height rods mounted within each plot. Flame height poles were constructed of galvanized pipe and painted alternating colors to permit easy determination of scorch height. The poles were painted in 10-cm sections from $57 \mathrm{~cm}$ to a height of $297 \mathrm{~cm}$ above ground. Each unit was self supporting, allowing installation without the need to core into the barrier surface.

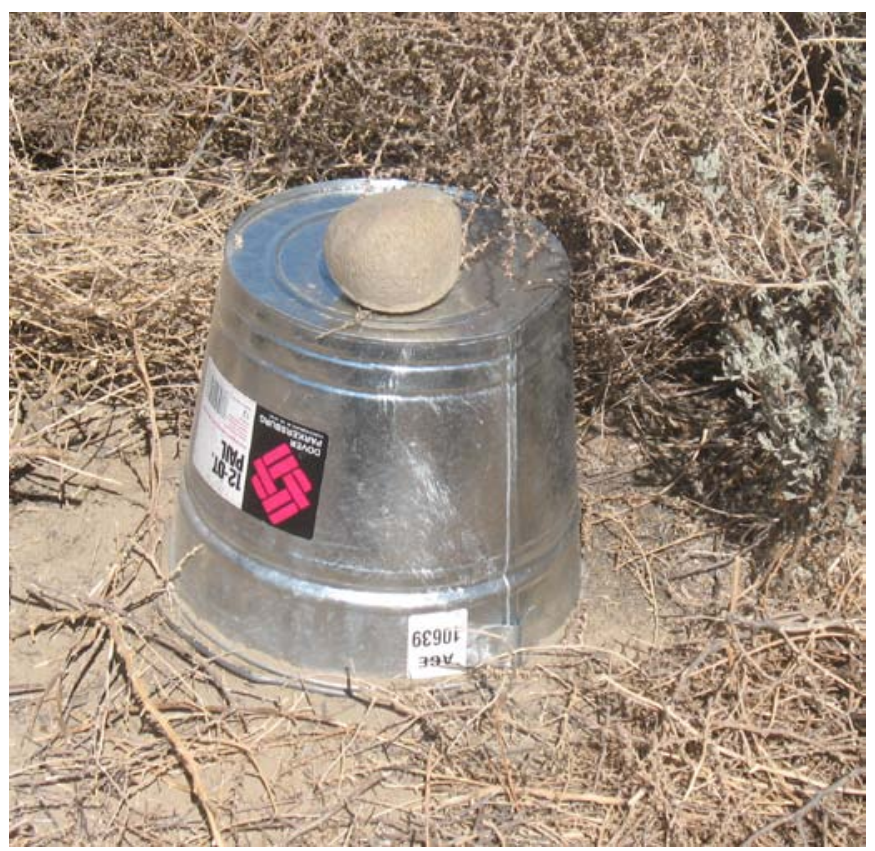

Figure 2.5. Inverted Galvanized Pail Used to Cover Minirhizotron Tubes. Tubes were first wrapped in fiberglass insulation.

The degree of fire intensity was scored in a relative fashion with little or no effect (bright white) assigned a value of 1 while the darkest carbonized areas were assigned a value of 5 . White painted strips were examined every $40 \mathrm{~cm}$ for seven assessments on each pole. Values were averaged on each pole, and the pole average was used to create a fire intensity map. To verify flame-heights inferred from ocular observation and to track soil temperatures, Type-K thermocouples were installed on the flame height rods at $1.5 \mathrm{~cm}$ (0.6 in.) below the soil surface and at $0 \mathrm{~cm}$ (Figure 2.8a). In addition, thermocouples were installed at five additional heights above the surface (Figure 2.8b): $1 \mathrm{~cm}(0.4 \mathrm{in}$.), $10 \mathrm{~cm}$ (4 in.), $30 \mathrm{~cm}$ (12 in.), $100 \mathrm{~cm}$ (39.4 in.), and $200 \mathrm{~cm}$ (78.7 in.). A thermocouple wire can be seen mounted at a right angle to the pole at a height of $2 \mathrm{~m}$ (Figure 2.8b). Each of the 63 thermocouples was attached to a HOBO datalogger (Figure 2.4c) to record temperatures. Temperatures were measured once per second starting 3 hours before the fire until about 9 hours after the fire. The resulting data were used to map the relative intensity of the fire across the burned surface. 


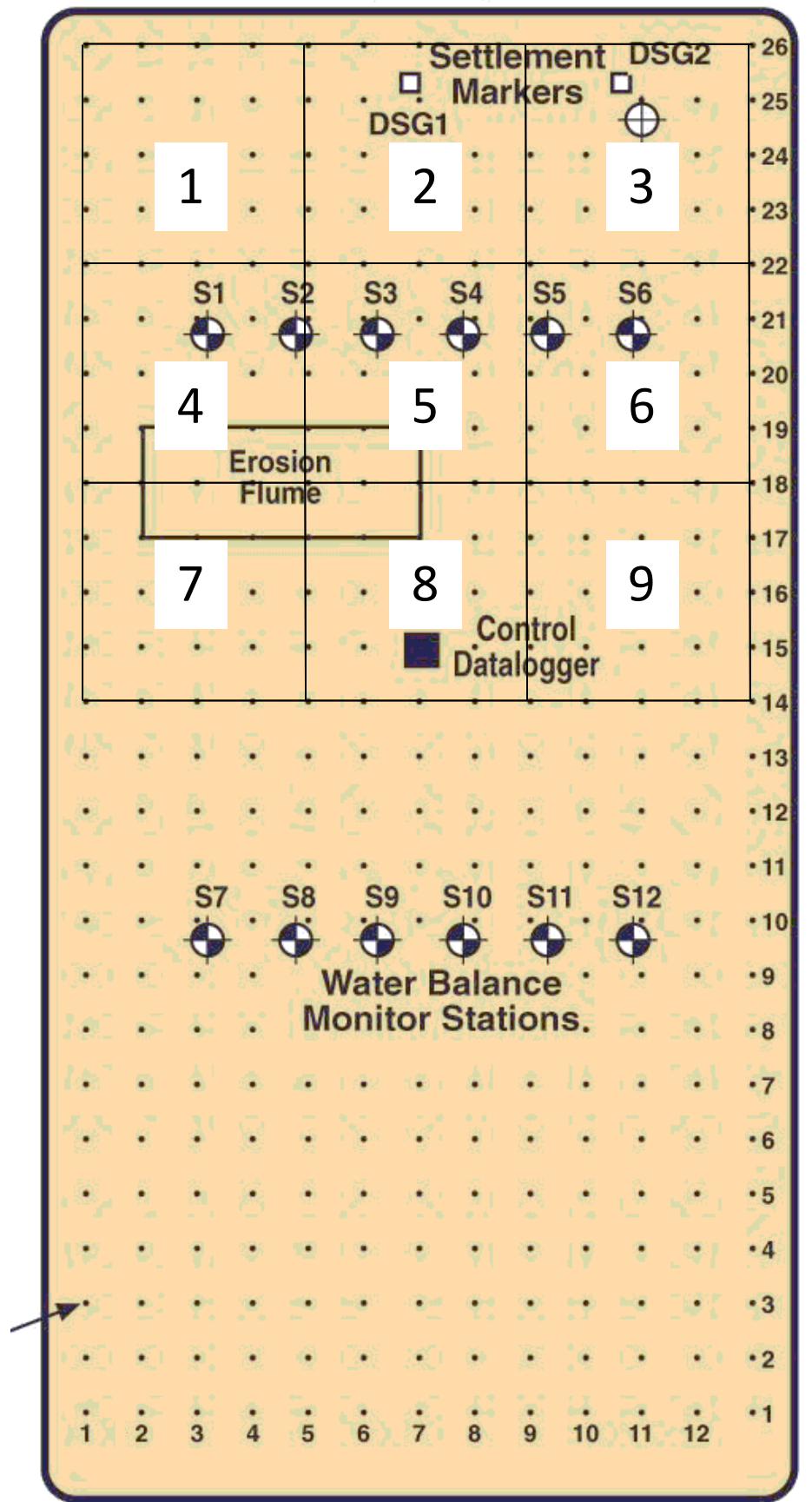

Figure 2.6. Schematic Plan View of the Barrier's Surface Showing Monitoring Stations, the Runoff Plot, the $3 \times 3$ M Grid, and the Nine (1 through 9) $12 \times 12 \mathrm{~m}$ Plots to be Used for Comparing Effects of Fuel Loads on Fire Intensity 


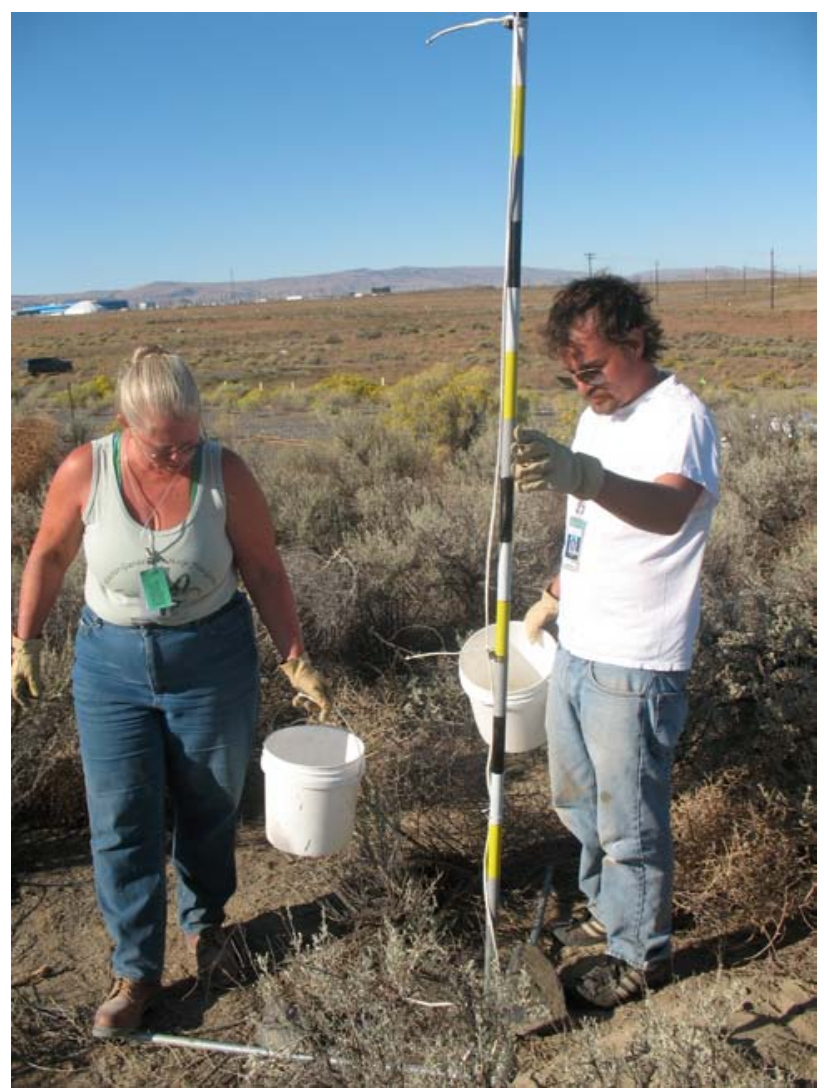

Figure 2.7. Photograph of Fire Pole Used to Measure Flame Characteristics and to Secure Thermocouples

(a)

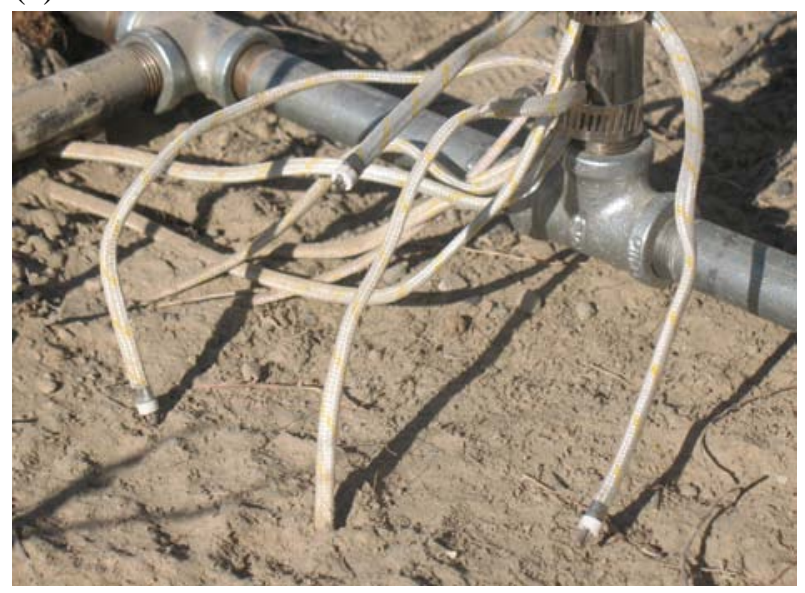

(b)

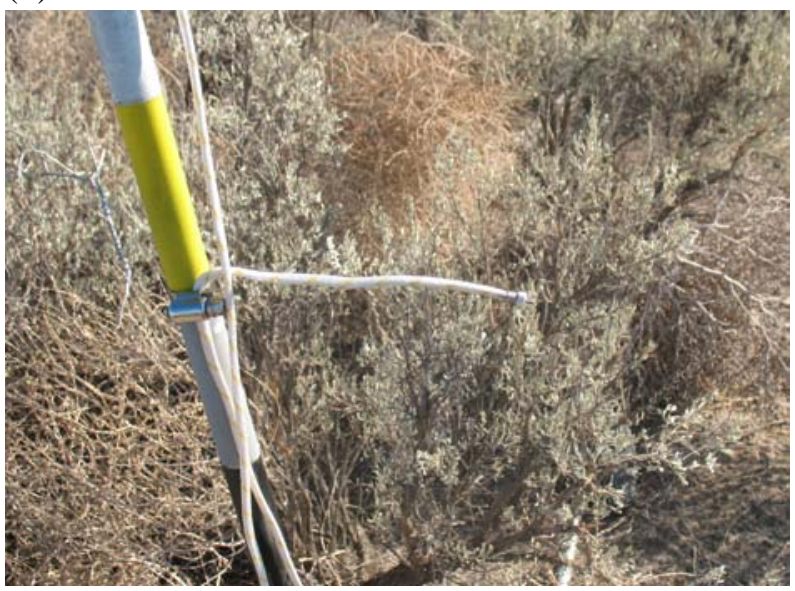

Figure 2.8. Thermocouples for Measuring Soil and Air Temperature Installed on Flame Height Scaffold: (a) Thermocouples Were Installed $1.5 \mathrm{~cm}$ Deep, at the Surface $(0 \mathrm{~cm}), 1 \mathrm{~cm}$, $10 \mathrm{~cm}$, and $30 \mathrm{~cm}$, and (b) Above-Ground Thermistors Were Installed at $100 \mathrm{~cm}$, and $200 \mathrm{~cm}$. 


\subsection{Ecological Characterization}

Information on plant characteristics, small mammal diversity, and use of the barrier by mammals was collected before the controlled burn. Measurements were made at the site to assess plant species abundance, ground cover, and seed-bank composition. In addition, biological activity was assessed by measuring soil carbon dioxide flux of animal and insect use of the barrier. Plant measurements were collected on the north (formerly irrigated) section and south (formerly non-irrigated) section of the barrier as well as on the north and west side-slopes. Measurements were also made at two analog sites at the McGee Ranch, the source of silt loam used in the construction of the barrier. One analog site apparently has not burned in decades, and the other had a fire about 8 years ago. These plant communities provide context to the communities on the barrier surface.

The resulting information is needed to understand the role of ecological processes on barrier function and to quantify the impact of fire on these processes, including the disclimax plant associations that may occur after a major disturbance.

\subsubsection{Fuel-Load Characterization and Modification}

Fuel-load plays an important role in the extent of combustion of vegetation and the long-term changes in soil organic matter as well as total and available fractions of nutrients and trace elements (DeMacro et al. 2005). Thus, pre-burn site characterization included assessing the available fuel load. As shown in Figure 2.9, significant differences in plant density and fuel load were observed on the surface. Ground cover was particularly low in the northeast quadrant (see Figure 2.2).

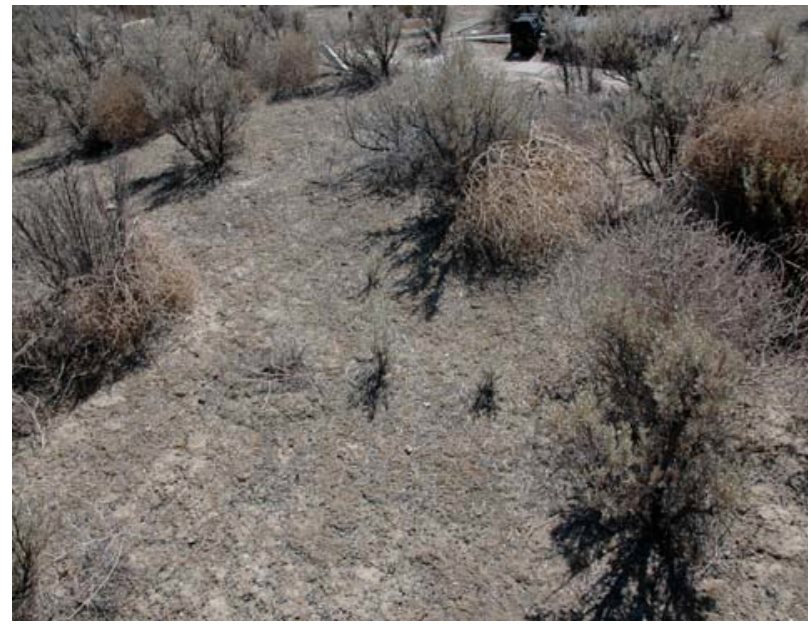

(a)

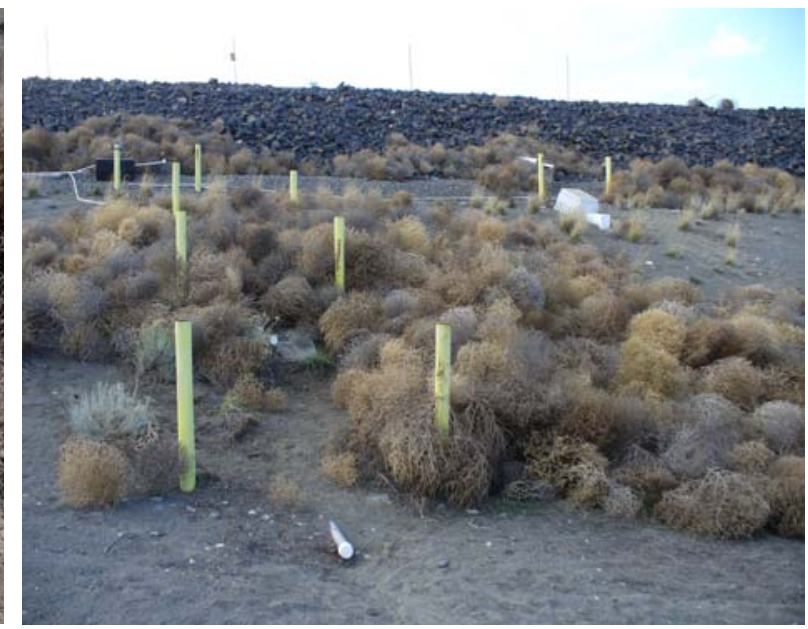

(b)

Figure 2.9. Photographs of the Barrier's Surface: (a) Sparse vegetation on the surface suggesting need for increased fuel load to emulate realistic conditions. Some Salsola kali (tumbleweed) was already logged among sagebrush plants, and (b) the rip rap side slope of the barrier shows an accumulation of tumbleweed. Dead sagebrush and tumbleweed were imported to the barrier surface to increase the fuel load.

This quadrant has traditionally shown a low shrub density and high grass cover, but at the time of sampling, grasses were also mostly absent. 
Shrub biomass that could serve as fuel was determined by measuring the canopy characteristics, including height, greatest width, and greatest diameter at right angles to the greatest width on the shrubs. Measurements were made on ten individual shrubs off the barrier surface that spanned the range of shrub sizes on the barrier surface. These shrubs were then harvested, weighed, dried, and weighed again to the fuel moisture content. Canopy characteristics were then measured on at least 30 individual $A$. tridentata shrubs on the barrier surface to estimate shrub fuel density. The biomasses of other fuel components on the surface were also estimated. Some areas of the barrier surface were quite sparse in vegetative cover and required an increase in biomass to reach representative fire intensities and severities (e.g., Figure 2.9a). Other fuel components included Salsola kali (tumbleweed). Tumbleweed is already lodged among the A. tridentata shrubs on the surface (Figure 2.3, Figure 2.9), and more may be brought in to confirm a complete burn of the surface. Although some tumbleweed was found near the barrier, it was still necessary to import tumbleweed from other areas. Figure 2.10 is a shows a photograph of the truck used by the tumbleweed management crew to collect and transport tumbleweed across the Hanford Site.

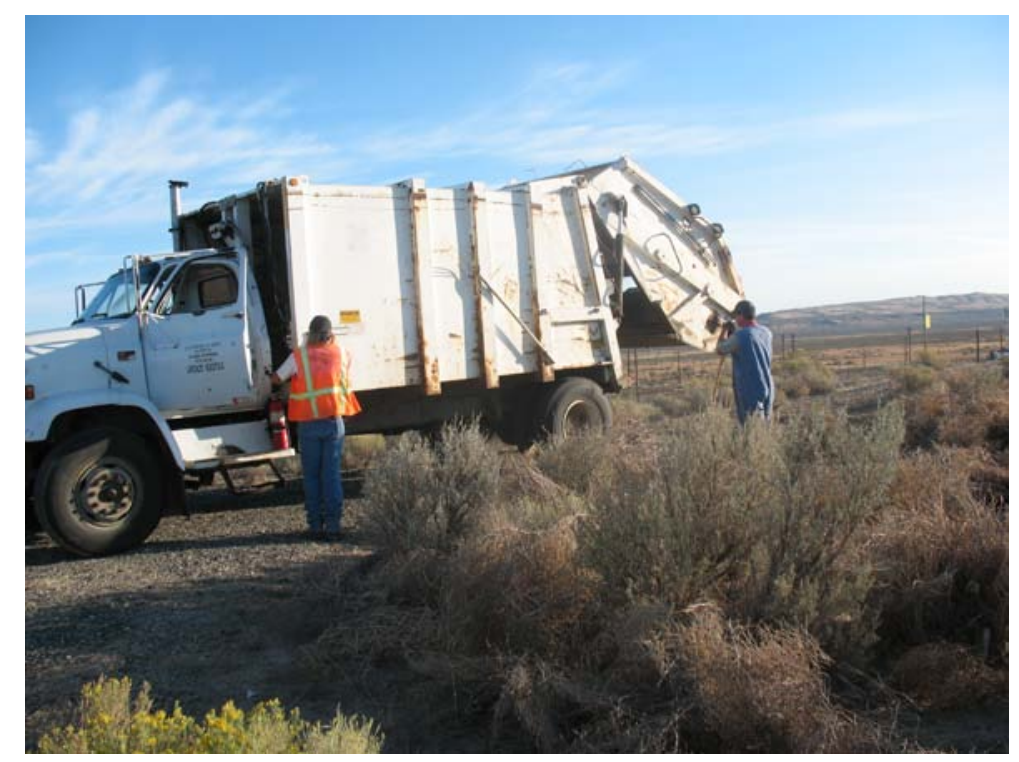

Figure 2.10. Unloading of Tumbleweed Brought to the Barrier to Increase Fuel Load. Over 2 tonnes of tumbleweed were added to the surface.

Over 2 tonnes of clean tumble weeds were brought to the barrier from around the 200 East area. Tumbleweeds were dumped onto the gravel road to the north of the barrier and distributed from there. Subsamples of the imported fuel were weighed and dried to determine the moisture content. The dry tumbleweeds were spread across the surface of the barrier by hand (Figure 2.11) to achieve the randomly assigned fuel loads. Two fuel loads of approximately 10.5 and 12.8 tonnes/ha were assigned to the nine $12 \times 12$ m plots. 


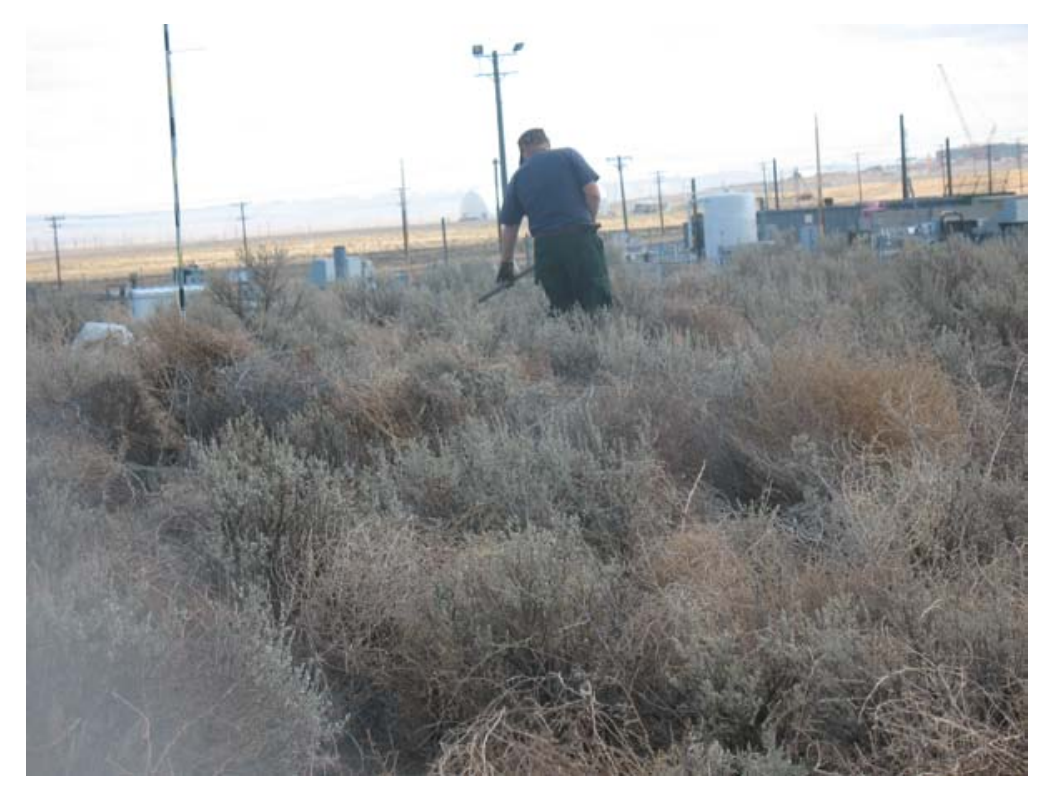

Figure 2.11. Redistribution of Imported Tumbleweed Across the Barrier to Achieve Different Fuel Loads for the Controlled Burn. In this photograph, Captain Jerry Keeline of the Hanford Fire Patrol is shown redistributing tumbleweed with a rake.

\subsubsection{Plant Root Distributions}

Twelve minirhizotrons, constructed of clear acrylic tube, were installed on the barrier at an angle of $45^{\circ}$ to the surface to measure root distributions as part of the CERCLA treatability test (DOE 1998). These tubes were used for root-length density measurements, but have not been used in over 10 years. The tubes were assessed to determine their condition and cleaned. Tubes are ordered from the west (1) to east (6) sides of the surface. Tubes were examined on December 11, 2008. The rubber gaskets holding the tops in place were in various states of decomposition. Some were very tight while others were easier to pull out of the tubes. Water had collected in the bottom of all of the tubes. This water was removed using a small sump pump and volumes ranged from 535 to $695 \mathrm{~mL}$ with an average of $598 \pm 26.7 \mathrm{~mL}$ for tubes 2 through $6(n=5)$. Water in the first tube was not measured. The tube covers had been in place for 10 years, and the water may have accumulated by condensation. It was observed that tubes that were well sealed had more water than those in which the water could easily be removed from the tubes.

Plans to map pre- and post-burn root length densities at the barrier never materialized. The available instrument was a 15-yr old Circon Agricultural Camera minirhizotron system, initially purchased for use in the treatability test that started in 1994. Several attempts were made to complete these measurements through early March 2009, but low temperatures appeared to have affected operation of the root camera. The plan for data collection was modified to collect "pre-burn" data from the unburned half of the barrier as conditions permitted. Attempts were again made to collect these data in the summer. The camera continued to malfunction, and the vendor could not guarantee that the system could be repaired, so no root data have been collected. Efforts are being made to acquire a more modern system to monitor rootlength densities. 


\subsubsection{Plant Species Composition}

Wildfire can affect the floristic composition of plant communities. Post-fire recovery and plant community composition depends on a number of interacting variables, including the time since the most recent fire, the length of the inter-fire intervals, and the variability of the length of the inter-fire intervals. There are essentially no data documenting these effects on engineered ecosystem-like barriers. However, there is evidence that species composition of the barrier surface has changed since the surface was planted in 1994. Species richness has decreased from 35 to 10 from 1997 to 2008. It was therefore anticipated that species richness would change after the fire, which removed the dominant Artemisia tridentata cover. To quantify fire effects on species composition, the composition was determined on the burned half of the surface, the unburned half of the surface, on the north and west side slopes of the barrier, and at the two analog sites at the McGee Ranch. Surveys of vegetation were conducted between August 3 and September 13, 2009. Species were identified in the field or in the laboratory with collected specimens. All naming follows U.S. Department of Agriculture-Natural Resources Conservation Service (USDANRCS) (2009).

\subsubsection{Soil Cryptograms}

Cryptogams function as soil builders, forming a spongy layer that absorbs moisture, provides nitrogen and other nutrients for plant growth, and helps to protect soil from erosion. Freezing conditions cause the cryptogamic crust to uplift and crack, providing germination sites for seeds. Soil cryptogams gradually appear on soils after disturbance and eventually will have an impact on soil structure and seed banks (Boudell et al. 2002). Species composition and general cover, including soil cryptograms, were examined at the barrier surface and at the two McGee Ranch analog sites to document effects of fire and time for establishment. Soil cryptogams were collected from all sites and later identified (Link et al. 2000). Cover was visually assessed as for other cover categories.

\subsubsection{Shrub Density}

Deep-rooted evergreen shrubs are the most efficient plants for extracting water from the water-storage layers of engineered barriers and are important to barrier function. Artemisia tridentata and Ericameria nauseosa were planted on the barrier, and $A$. tridentata has come to dominate after 15 years. Because $A$. tridentata tends not to recover after fire, it was necessary to determine if it and $E$. nauseosa would reestablish after fire. To this end, plant surveys included a measure of the occurrence and density of these two shrubs. The age structure of $A$. tridentata was also assessed to determine if the barrier population is similar to those at the McGee Ranch analog sites.

All shrubs were counted in each quadrat on the barrier surface after the fire and on the unburned half of the barrier, plus at both McGee Ranch analog sites. In each plot, the number of shrubs in three age classes (new seedlings, midsize young, and old large) was counted. At each analog site, 21 plots were established to characterize each site. The study areas at each site were marked as rectangles like the barrier surface. These analog sites were $40 \mathrm{~m} \times 80 \mathrm{~m}$. Plots at the old burned analog site were the same size as the quadrats on the barrier $(3 \mathrm{~m} \times 3 \mathrm{~m})$. Plots were larger $(6 \mathrm{~m} \times 6 \mathrm{~m})$ at the unburned analog site to efficiently capture variation in $A$. tridentata populations. 


\subsubsection{Ground Cover}

Vegetative groundcover serves to minimize surface runoff and erosion. Pre- and post-burn determinations of ground cover were made to document cover dynamics. In addition, cover was determined at the two McGee Ranch analog sites (old burn and unburned) to provide a comparison for the barrier surface. Ground cover was also determined on the north and west side slopes of the barrier.

Cover of grass, shrubs, forbs, litter, soil, and soil cryptogams was determined on the surface, on the side slopes, and at the two McGee Ranch analog sites. These measurements were made by visual inspection for each species and other classes (Daubenmire 1959, DOE/RL 1999). Soil and soil cryptogam cover estimates were combined for an estimate of bare ground cover for comparison with previous years. Cover was measured in all numbered quadrats on the surface of the barrier, except those in row 13, which forms the boundary between the burned and unburned portions of the barrier (Figure 2.6). Cover was determined in the same plots used for density at the two McGee Ranch analog sites. Cover class data were analyzed using the midpoint of a class. Cover on the side slopes was assessed with a modified Daubenmire technique. This approach divides a $0.5 \mathrm{~m}^{2}$ rectangular plot frame into fifty 1 - $\mathrm{dm}^{2}$ quadrats, allowing for less than $1 \%$ cover resolution. Fifteen plots were located on the west side slope, five in each of three transects from the top of the slope to the bottom. On the north side, nine plots were located, with three in each of three transects from the top to the bottom of the slope. All plots were lumped to compare cover types $(n=24)$. For statistical analyses, percent cover data were transformed according to Steele and Torrie (1960).

$$
\operatorname{arcSin} \sqrt{\frac{\% \text { Cover+ } 0.5}{100}}
$$

\subsubsection{Leaf Area Index}

The leaf area index (LAI) provides a measure of physiologically active vegetation and is used in agricultural applications to provide models with a measure of leaf area. The measure is useful also to help provide a measure of leaf area for arid land plant-physiology models. For the applications at the barrier and analog sites, the response is a combination of green leaf area and other shading, but not inactive material, such as dry grass leaves. It is useful to compare plant community types for potential active leaf area. It may provide a response close to a true value in A. tridentata where leaves are evergreen.

The LAI was measured on each study plot used to determine cover at the burned and unburned barrier areas and at the two McGee Ranch analog sites. The LAI was measured with an AccuPAR LP80 Ceptometer. Observations were taken in the center of each plot. Observations were also taken in 21 plots in each of the two analog sites. The LAI values were transformed using the square root because data were Poisson distributed (many very small values and few large values). Comparisons are made using transformed data while untransformed values are presented for easy interpretation. 


\subsubsection{Plant Water Status}

Measurements of water potential of plant leaves, or more exactly, the plant xylem pressure potential, are useful for comparing plant activity and soil water status. Xylem pressure potential was measured on plants with a Model 1005 Pressure Chamber Instrument (PMS Instruments) in the burned and unburned conditions on the barrier. Measurements were made just before dawn to assess maximal xylem pressure potential. Observations were made on A. tridentata, S. kali, and M. officinalis in the west, central, and east sides of the surface. In addition, measurements were taken on A. tridentata in the unburned condition in late afternoon to determine the lowest possible values.

\subsubsection{Post-Burn Biological Activity and Soil Carbon Dioxide Flux}

Soil respiration after fire generally decreases with reductions in biological activity and organic carbon. Biological activity was assessed nearly 1 year after the fire by comparing activity on the unburned and burned portions of the barrier surface. Respiration rates were compared under very dry surface soil conditions and after a rain that wetted the top $33 \mathrm{~mm}$ of the soil profile. Measurements of soil $\mathrm{CO}_{2}$ were made in situ with a Vaisala CARBOCAP ${ }^{\circledR}$ Hand-Held Model GMP343 carbon dioxide probe and a Model G70 CARBOCAP ${ }^{\circledR}$ Hand-field carbon dioxide meter. Measurements were made in a static diffusion chamber made of glass (Figure 2.12). Before each measurement, the edges where sealed with a small berm of dry soil placed along the bottom edge. The chamber then was covered with a black cloth that allowed essentially no photosynthetically active radiation to enter the chamber. This was measured with an AccuPAR LP80 Ceptometer. Observations were taken for 15 minutes. Steady-state respiration rates were achieved within a few minutes before data were recorded. Six replicates were taken for each testable condition. The depth to the bottom of the wetting front was measured with a meter stick for wetted soil tests.

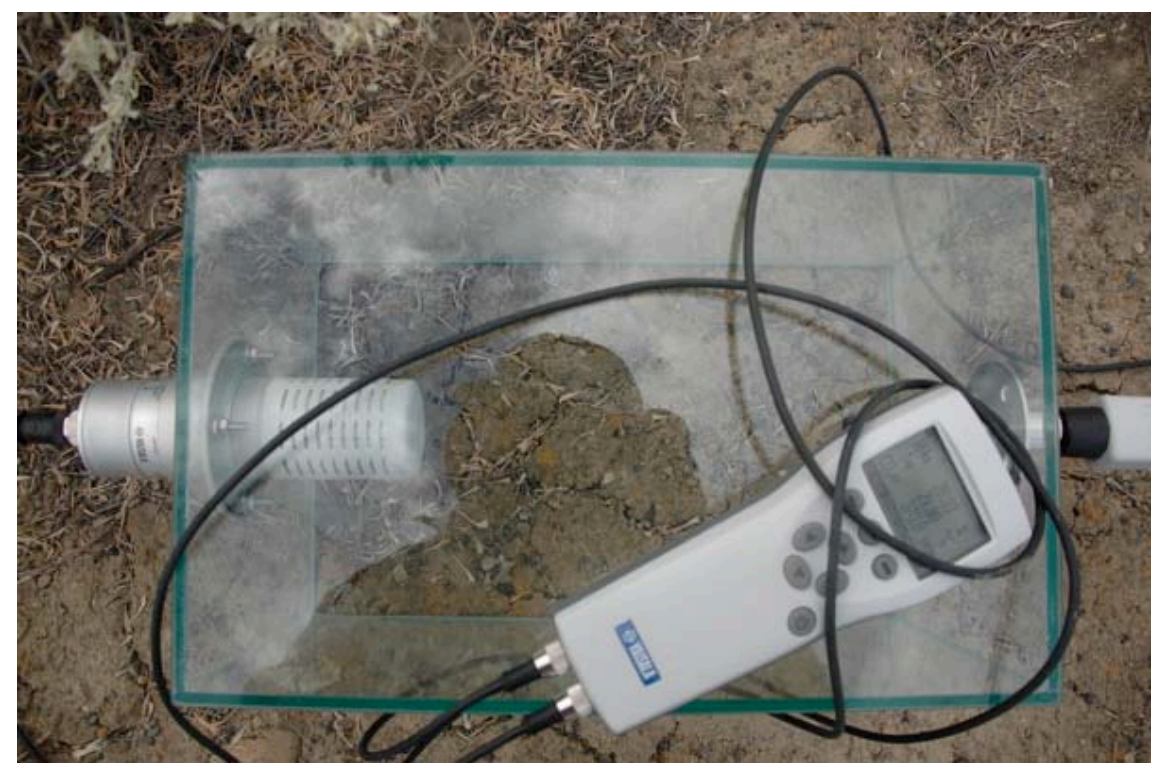

Figure 2.12. Static Diffusion Chamber with Sensors and Readout Device 


\subsubsection{Seed Bank Assessment}

Understanding fire effects on post-fire regeneration requires an understanding of the relationships between fire intensity and the survival of seeds stored in the soil. When considering the impact of wildfire, the ability of a plant species to re-sprout after fire and the ability to recruit from persistent seed banks are therefore two of the desirable attributes of the ideal species for revegetation. Two methods are commonly used to estimate the seed content of soils: 1) seed separation methods and 2) seedling emergence methods (Roberts 1981). To quantify the impact of fire on the seed content of the barrier soils, the seedling emergence method was used to assess the seed bank on the barrier surface and gravel side slopes.

The hypothesis to be tested was the effect of fire on the seed bank and the effect of location relative to canopies (under vs. between canopies). Topographic relief at the two analog sites allowed tests of the effect of canopy type and position on hummocks and swales on seed-bank density. This topographic variation potentially could form on a barrier surface. The pre- and post-burn seed banks of the barrier and side slopes, from the old burn community at McGee Ranch, and from the unburned mature community at the McGee Ranch were all compared.

For the seedling emergence tests, soil samples were collected from the various sites just before the fire (September 17 and 18, 2008) and just after the fire (September 30, 2008). Samples were physically paired on the surface for the before and after comparison. Samples were collected along the west, north, and east edges and randomly chosen under the canopy and between canopy pairs throughout the center of the burned area. Samples were collected on the north and west side slopes on September 26, 2008. Samples were collected at the old burn McGee Ranch site between December 9 and 11, 2008, and at the undisturbed mature plant community at the McGee Ranch site on November 18 and December 1, 2008. Samples were collected using a flat edge shovel $\left(\sim 0.05 \mathrm{~m}^{-2}\right.$ sample area). The depth of the sample, which was about $3 \mathrm{~cm}$ deep, captured the majority of seeds in these soils (Boudell et al. 2002). Samples were placed in paper bags and stored dry at room temperature until placed in the greenhouse in flats.

For the seedling emergence tests, soil samples were spread in trays in the climate-controlled Washington State University Tri-Cities Native Plant greenhouse. The greenhouse conditions were ambient light, the temperatures were above $20^{\circ} \mathrm{C}$, and there was high humidity and daily watering. Generally, the samples were spread in a layer $1 \mathrm{~cm}$ thick on top of potting soil in a flat $\left(0.142 \mathrm{~m}^{2}\right)$. Samples were placed in the greenhouse in flats between February 23 and March 5, 2009, for the barrier samples. Studies have shown that 95\% of the seedlings will emerge within 6 weeks using this method. The side slope and McGee Ranch samples were placed in the greenhouse in flats between August 6 and 11, 2009.

Germinated seedlings were identified and counted. Data were analyzed separately for each of the most common species and by summing all seedlings without regard to species in each experimental unit (field soil sample). The effect of canopy location on the seed bank was tested for the central portion of the surface with samples taken under $A$. tridentata canopies $(n=6)$ and from the interspaces between $A$. tridentata canopies $(n=6)$. The seed banks of the barrier before $(n=36)$ and after the fire $(n=36)$, side slopes $(n=18)$, the old burn community at McGee Ranch $(n=36)$, and the unburned mature community at McGee Ranch $(\mathrm{n}=36)$ were compared. 
The ability of a species to recruit from persistent seed banks is a desirable attribute of the ideal species for revegetation. The results of this test will therefore serve multiple functions. This will allow the density of species on the native soils of two McGee Ranch analog sites to be compared with the barrier, and changes resulting from the fire can be quantified. This will also allow an assessment of whether the species lost from the barrier vegetation over the years are still present as seeds in the soil. More importantly, the results will support the formulation of hypotheses about changes in the seed bank during secondary succession and the prediction of changes in species richness and seed density.

\subsubsection{Small Mammal Habitat and Barrier Use}

The important ecological role of small mammals, along with their ubiquitous nature, makes them important tools in clarifying and comparing the effects of fire on habitat change. To understand the pattern of small mammal communities within engineered ecosystems altered by fire, the composition, demography, and variation of small mammals and insects on the barrier were also examined. At the Hanford Site, prominent species of small mammals include Great Basin pocket mice (Perognathus parvus), deer mice (Peromyscus maniculatus), northern pocket gophers (Thomomys talpoides), western harvest mice (Reithrodontomys megalotus), and N. grasshopper mice (Onychomys lucogaster). Additionally, other organisms, such as darkling beetles, spiders, lizards, coyotes, and badgers are responsible for reworking the surface soils. Consequently, characterizing the presence/absence of these organism's activities above an engineered surface barrier used for long-term isolation of Hanford Site wastes may help evaluate and optimize barrier designs. These organisms use of an area can be greatly influenced by the wildfires.

Pre-burn surveys were conducted across the entire surface to document evidence of use and intrusion (burrowing) by insects and small mammals. Small mammal traps were used to positively identify vertebrates on the surface. Evidence of animal use was observed on the surface and included direct observation (traps) as well as the presence of droppings, tracks, nests, burrows, holes, and resting spots. A small mammal trapping event and the reconnaissance of indirect evidence of animal activity was performed by staff of Environmental Assessment Services (EAS) in September 2008 just before a controlled burn of the surface barrier area.

Two small mammal arrays of Sherman live traps were placed on the surface; one array was located on the burned half, and one was located in the unburned half. Each array consisted of three trap lines, each with three traps spaced $10 \mathrm{~m}$ apart ( $30 \mathrm{~m} \times 30 \mathrm{~m}$ area). The traps were placed in the field on September 15, 2008, and left for 1 day before baiting and opening to allow small mammals to acclimate to the new objects. Both small mammal arrays were opened the evening of September 16, 2008, and then checked and re-baited with a mixture of peanut butter and oatmeal each morning until the survey was completed. Species, age, and sex were determined for all small mammals captured, and each animal was given a mark to identify the occurrence of re-captured specimens. The relative abundance of small mammals was estimated for two areas by dividing the total number of traps and number of nights by the total number of new captures and then multiplied by 100. Animal activity such as scat, tracks, and burrows were noted in each area while field crews were mobilizing/demobilizing and performing daily trap checks.

The post-burn surface was examined for evidence of use and intrusion (burrowing) by insects and small mammals on September 13, 2009. This was done by carefully inspecting 288 of 300 sample 
squares on the surface. The row between the burned and unburned portions of the surface was not assessed. Indications of animal use included direct observation and the presence of droppings, tracks, nests, burrows, or holes, and gall formation on A. tridentata. Hole size was classed as large $(>\sim 2 \mathrm{~cm}$ diameter) or small. Holes in each class were counted in each plot. The degree of gall formation and the amount of feces were classed into high and low groups. A high degree of gall formation was noted when any shrub had numerous (> 50) galls. A large number of rabbit feces was noted when feces were concentrated in patches while a plot with few feces that were widely distributed was classed as low. The Van der Waerden non-parametric test was used when data were not normally distributed to compare responses in the burned and unburned treatments. The relationship between rabbit feces and cover of Elymus wawawaiensis was determined by relating the percentage of plots in each of 25 rows that had feces with mean percent cover of $E$. wawawaiensis in each row. Each of the 25 rows has 12 plots.

\subsection{Soil Nutrient Status}

Macronutrients can be broken into primary and secondary nutrients. The primary nutrients are nitrogen $(\mathrm{N})$, phosphorus $(\mathrm{P})$, and potassium $(\mathrm{K})$. These major nutrients usually become deficient first because plants use large amounts for their growth and survival. The secondary nutrients are calcium (Ca), magnesium (Mg), and sulfur (S). These are usually present in large enough quantities to preclude the need for fertilizer. Calcium and magnesium are usually added to acidic soils. Sulfur is usually found in sufficient amounts from the slow decomposition of soil organic matter. Micronutrients are also essential for plant growth, but are needed in only very small quantities. Micronutrients include boron (B), copper (Cu), iron (Fe), chloride (Cl), manganese (Mn), molybdenum (Mo), and zinc (Zn). In addition to soil nutrients, soils were also analyzed to quantify $\mathrm{pH}$, electrical conductivity, and soil organic matter. Soil samples were analyzed by X-ray diffraction (XRD) techniques to determine the effects of fire on mineralogy and pedogenesis. Samples were also analyzed to determine the surface area and cation exchange capacity.

The geochemical analyses (excluding mineralogy and surface area) were conducted by Northwest Agricultural Consultants (NWAg) of Kennewick, Washington. NWAg is a member of the North American Proficiency Testing Program (NAPT; http://www.naptprogram.org ), which is an activity overseen by the Soil Science Society of America. Methods of soil analysis are explained below (from the NAPT website):

"The Proficiency Assessment program (PAP) is a voluntary program offered as a service of the Soil Science Society of America (SSSA), Madison, WI, and operated as a part of the North American Proficiency Testing program (NAPT), and is administered by the NAPT Oversight Committee. While the PAP program is offered as a voluntary service to all soil testing laboratories, this program has been adopted by the NRCS as assurance that soil test analyses are being performed using validated testing methods. The PAP program is required by the NRCS for soil analysis laboratories analyzing soils for federal government programs involved with the development of nutrient management plans in certain Western US states.”

The Natural Resources Conservation Service (NCRS) is an arm of the United States Department of Agriculture (USDA). NWAg is a member of the PAP and is listed as a PAP-certified lab in 2009 (http://www.naptprogram.org/pap/labs ). As noted above, the emphasis of the PAP is nutrient management for the NCRS. The data collected and used for the barrier burn study was for the same purpose - nutrient status (before and after the burn). The data collected for this report were not collected 
to support regulatory purposes, to support of the Tri-Party Agreement, or to meet client-imposed specific QA programmatic requirements for reportable data that may put PNNL at risk.

The procedures used by NWAg for laboratory analyses are documented in Gavlak et al. (2003). Table 2.1 identifies the specific procedure, sub-method ID, and sub-method title for each measured variable. Each procedure is summarized below to provide enough detail to understand what was done; to replicate the measurements, the reader must obtain the full original procedure from Gavlak et al. (2003). The applicable method detection limits, on a dry soil basis, are summarized in

Table 2.2.

Table 2.1. Laboratory Procedures Used by Northwest Agricultural Consultants for Geochemical Analyses (Obtained online from http://cropandsoil.oregonstate.edu/wera103/soil methods (WSL 2003) on 1 May 2009).

\begin{tabular}{|c|c|}
\hline $\begin{array}{l}\text { Variables Measured in } \\
\text { Burn Study }\end{array}$ & $\begin{array}{l}\text { Sub-method ID } \\
\text { Sub Method Title }\end{array}$ \\
\hline Nitrate-N & $\begin{array}{l}\text { S-3.10: SOIL NITRATE NITROGEN } \\
\text { KCl Extraction / Cd-Reduction Method }\end{array}$ \\
\hline Ammonium-N & $\begin{array}{l}\text { S-3.50: SOIL AMMONIUM NITROGEN } \\
\text { KCl Extraction / Exchangeable Ammonium }\end{array}$ \\
\hline P-Bicarb & $\begin{array}{l}\text { S-4.10: ESTIMATION OF AVAILABLE SOIL PHOSPHORUS } \\
\text { Sodium Bicarbonate (Olsen et al.) Method }\end{array}$ \\
\hline K Bicarb & $\begin{array}{l}\text { S-4.10:ESTIMATION OF AVAILABLE SOIL PHOSPHORUS } \\
\text { Sodium Bicarbonate (Olsen et al.) Method }\end{array}$ \\
\hline $\mathrm{Ca}$ & $\begin{array}{l}\text { S-5.10: EXTRACTABLE POTASSIUM, CALCIUM, MAGNESIUM, } \\
\text { AND SODIUM } \\
\text { Ammonium Acetate Method }\end{array}$ \\
\hline $\mathrm{Mg}$ & $\begin{array}{l}\text { S-5.10: EXTRACTABLE POTASSIUM, CALCIUM, MAGNESIUM, } \\
\text { AND SODIUM } \\
\text { Ammonium Acetate Method }\end{array}$ \\
\hline $\mathrm{Na}$ & $\begin{array}{l}\text { S-5.10: EXTRACTABLE POTASSIUM, CALCIUM, MAGNESIUM, } \\
\text { AND SODIUM } \\
\text { Ammonium Acetate Method }\end{array}$ \\
\hline Organic Matter & $\begin{array}{l}\text { S-9.10: SOIL ORGANIC MATTER } \\
\text { Walkley-Black Titration Method }\end{array}$ \\
\hline $\mathrm{pH}$ & $\begin{array}{l}\text { S-2.20: SOIL } \mathrm{pH}(1: 1) \\
\text { Soil:Water Ratio Method }\end{array}$ \\
\hline 1:01 Conductivity & $\begin{array}{l}\text { S-2.20 for soil preparation and S-2.30 for measurement of EC (soil:water } \\
\text { ratio } 1: 1 \text { ) }\end{array}$ \\
\hline $\begin{array}{l}\text { Cation } \\
\text { Exchange Capacity }\end{array}$ & EPA METHOD 9081 \\
\hline Saturated Paste & S-1.20: SATURATION PASTE SOLUBLE SALTS EC $\mathrm{e}_{\mathrm{e}}$ \\
\hline
\end{tabular}


Table 2.2. Method Detection Limits for Soil Nutrient Analyses

\begin{tabular}{ll}
\hline Analytical Method & \multicolumn{1}{c}{ Detection Limits } \\
\hline Saturation Paste Analysis & $0.01 \mathrm{dSm}^{-1}\left(\mathrm{mmhos} \mathrm{cm}^{-1}\right)$ \\
pH and Electrical Conductivity & $0.01 \mathrm{pH}$ units \\
Nitrate Nitrogen & $0.5 \mathrm{mg} \mathrm{kg}^{-1}$ \\
Ammonium Nitrogen & $0.2 \mathrm{mg} \mathrm{kg}^{-1}$ \\
Nitrogen Mineralization Potential & $0.2 \mathrm{mg} \mathrm{kg}^{-1}$ \\
Extractable Phosphorus and Soil Bases & $2.0 \mathrm{mg} \mathrm{kg}^{-1}$ \\
Micronutrients & $0.1 \mathrm{mg} \mathrm{kg}^{-1}$ for Zn, Cu, Mn, and Fe \\
Organic Matter & $0.020 \% \mathrm{~N}^{-1}$ \\
Inorganic Carbon & $0.2 \% \mathrm{CaCO}_{3}$ equivalent \\
Cation Exchange Capacity & $1.0 \mathrm{cmol} \mathrm{kg}^{-1}$ (or meq/100 gm) \\
\hline
\end{tabular}

Soil $\mathrm{pH}$ is a measure of the relative acidity or alkalinity of the soil solution that is in equilibrium with the solid particles. Knowledge of soil $\mathrm{pH}$ is important to assess soil chemical properties and relative nutrient availability. Macronutrients tend to be less available in soils with low $\mathrm{pH}$. Micronutrients tend to be less available in soils with high $\mathrm{pH}$. Measuring the electrical conductivity (EC) is a simple way to determine the content of soluble salts and hence soil salinity. More precise measurements of EC were made with saturated soil pastes. Inorganic nitrogen $(\mathrm{N})$ in soils is predominantly in the form of nitratenitrogen $\left(\mathrm{NO}_{3}-\mathrm{N}\right)$ and ammonium-nitrogen $\left(\mathrm{NH}_{4}-\mathrm{N}\right) . \mathrm{NO}_{3}-\mathrm{N}$ is usually determined to estimate available $\mathrm{N}$ in agricultural soils whereas $\mathrm{NO}_{3}-\mathrm{N}$ and $\mathrm{NH}_{4}-\mathrm{N}$ is often determined in tree nursery and forest soils. For this work, both $\mathrm{NO}_{3}-\mathrm{N}$ and $\mathrm{NH}_{4}-\mathrm{N}$ were determined on $\mathrm{KCl}$ extracts. Phosphorus $(\mathrm{P})$ is a macronutrient belonging to the group of 17 nutrients that are essential for plant growth, and deficiencies can curb growth and delay maturity. Soil organic matter values are typically used to estimate potential nitrogen mineralization and were therefore determined in pre- and post-burn samples. Cation exchange capacity (CEC) is the measure of a soil's ability to retain readily exchangeable cations that neutralize the negative charge of soils, and it was also determined with EPA Method 9081. 


\subsection{Characterization of Soil Hydrophysical Properties}

Soil samples were characterized to determine fire effects on hydrophysical properties. In situ and laboratory measurements continued after the burn, according to the schedule developed in the test plan, to quantify changes and their persistence resulting from the fire. Hydrophysical measurements included particle-size distributions, saturated hydraulic conductivity, unsaturated hydraulic conductivity, and soil wettabilty. Measurements were made before the burn, in situ, and on samples to establish the initial conditions. Most of the measurements were repeated at intervals over the past year with a set of measurements being made almost 1 year after the burn.

\subsubsection{Surface-Layer Composition and Inflation/Deflation}

During construction, the top $1 \mathrm{~m}$ of fine-soil surface layer of the barrier was amended by adding $15 \mathrm{wt} \%$ pea gravel as a means of protecting soil erosion (Ligotke 1994, Ward et al. 1997, DOE 1998). Long-term changes in the surface layer composition may be expected as the surface ages under both deflationary and inflationary influences of soil loss or gain. Changes in surface-layer composition may also be expected following a fire that removes the vegetation and surface litter that protects the soil surface from raindrop impact and erosion by water and wind.

The surface composition of soil samples collected from the barrier's surface was also measured. Four core samples were collected from the four $3 \mathrm{~m} \times 3 \mathrm{~m}$ quadrants of each large plot. Samples were collected by coring the soil column in two increments, one from $0 \mathrm{~cm}$ to $2 \mathrm{~cm}$ to collect a "surface" sample and the other from $2 \mathrm{~cm}$ to $10 \mathrm{~cm}$ to collect a "bulk" sample. Each sample was analyzed to determine the particle-size distribution. Soil samples were separated into four grain-size fractions, namely, gravel, sand, silt, and clay, and sub classes (very coarse, coarse, medium, fine, and very fine) based on the logarithmic Udden-Wentworth grade scale (Wentworth 1922). In this scale, the boundaries between successive size classes differ by a factor of two. Dry sieving was used to separate gravel and other particles greater than $2 \mathrm{~mm}$ in diameter. The laser diffraction method was used to determine particle-size distributions of the $<2$-mm fraction. Sample-size fractions by weight were converted into percent-by-weight passing each sieve and plotted as a curve on a semi-logarithmic scale to give the grainsize distribution. The percentage of each size fraction was then used to determine texture according to the USDA classification and the Unified Soil Classification System specified by ASTM D2487-00 (ASTM 2000). Grain-size statistics were calculated from the grain-size distributions with the methods described by Ward et al. (2006). The particle-size moments of the distributions and the related coefficients, e.g., coefficient of uniformity, $C_{u}$, and coefficient of curvature, $C_{c}$, $d$-values of the gradation curve $\left(d_{16}\right.$, $\left.d_{50}, d_{84}\right)$ were calculated from the grain-size distributions with the methods described by Folk (1980). These data were used to quantify changes in the surface layer resulting from the fire.

Soil inflation and deflation are likely to occur after a fire with the loss of plant cover. During deflationary periods, the visible exposed concentration of pea gravel at and near the surface is expected to increase and form armor as soil particles are removed by wind. During inflationary periods, a layer of soil that is largely free of pea gravel is expected to form on the surface. The pattern of inflation and deflation was mapped using 66 erosion pins on the burned half of the barrier. Measurements were taken before and nearly 1 year after the fire. These data should reveal the ability of the surface to resist erosive stresses after fire and provide insight into changes in surface composition relative to the bulk composition of the top $1 \mathrm{~m}$ of admix. The height above the soil surface of 66 steel stakes was measured with a meter 
stick. The 66 measurement stakes were distributed around the edges and throughout the central region of the surface. A metal washer was placed on the west side of each stake and used as a measuring base. The measuring technique was used before the fire and repeated on August 13, 2009, nearly 11 months after the fire. Measurements were taken by viewing the interception of the top of the metal stake with the millimeter-ruled meter stick. This was done in the same manner before and after the fire to minimize bias and parallax.

\subsubsection{Characterization of Hydraulic Properties}

Estimates of hydraulic properties were derived from in situ measurements of hydraulic conductivity using the Guelph permeameter, with one-head and two-head analyses and with the Guelph tension infiltrometer. Saturated hydraulic conductivity was measured at nine different locations on each $12 \mathrm{~m} \times 12 \mathrm{~m}$ plot using a Guelph permeameter (Reynolds et al. 1985). With the Guelph permeameter method, water flux into the soil is measured until a saturated bulb is formed around the borehole, and the outflow of water from the storage cylinder reaches a constant value. The saturated hydraulic conductivity is then calculated with the constant-head permeameter method, based on the Reynolds and Elrick (1985) solution of Richards' equation for steady flow out of a well. In arid environments, water movement in the surface soils typically occurs as unsaturated flow, which is controlled by the unsaturated hydraulic conductivity of the soil. Field measurements of unsaturated hydraulic conductivity $(\mathrm{K}(\psi))$ were measured on each of the $12 \mathrm{~m} \times 12 \mathrm{~m}$ plots using a Guelph tension infiltrometer (Reynolds 1993). Since the Guelph permeameter and tensiometer methods yield only point measurements, four measurements were made inside each $12 \mathrm{~m} \times 12 \mathrm{~m}$ plot (one in each $3 \mathrm{~m} \times 3 \mathrm{~m}$ quadrant) to provide representative values of the hydraulic conductivity before and after the burn. Both methods allowed the alpha parameter to be calculated, which is the inverse of the bubbling pressure.

An important phenomenon affecting infiltration or water movement in soils after fire is the hydrophobization of originally wettable mineral particles by coatings of organic substances of different origin (Wallis and Horne 1992). To quantify the importance of this phenomenon at the barrier, soil water repellency was measured in situ and on soil samples collected before the burn and at various times after the burn. Water repellency was measured with the water-drop penetration time (WDPT) test (Dekker and Ritsema 1994, Dekker 1998). The WDPT test was performed by placing a water drop on the soil surface and recording the time required for the water to infiltrate. Soil cores of $1.9 \mathrm{~cm}(3 / 4 \mathrm{inch})$ diameter were taken to a depth of $20 \mathrm{~cm}$. The water-droplet penetration test was conducted on cores from $0 \mathrm{~cm}$ to $20 \mathrm{~cm}$ in 5-cm increments. The soil $(<2 \mathrm{~mm})$ was placed on a Petri dish and the surface smoothed. Three drops of distilled, de-ionized water, each containing $36 \mu \mathrm{L}$, were then randomly placed on the air-dry sample, and the penetration time was measured. The median value of the infiltration time of the three drops was considered as the drop penetration time at the analyzed depth, and the soil was considered hydrophobic if the WDPT was greater than 5 seconds (DeBano 1981). The maximum time allowed for water-droplet penetration was 600 seconds. Following the initial measurement, three additional measurements were made with the final set being made almost $1 \mathrm{yr}$ after the fire.

The effect of fire on soil moisture profiles and water storage was determined from neutron probe measurements of soil water content. Water-content profiles were measured at approximate 1-month intervals following the fire to document changes in storage. Measurements were taken at $0.15-\mathrm{m}$ intervals in the 2-m-thick fine-soil layer. 


\subsection{Controlled Burn}

Prescribed burns are typically conducted under controlled settings to prevent escape, using fuel breaks and ignition patterns as control measures. A controlled burn was used to quantify the effects of the fire on barrier performance. The burn was initiated and managed by the Hanford Fire Department (HFD). The north section of the barrier was divided into nine 12-m $\times 12-\mathrm{m}$ plots, and each plot was randomly assigned one of two fuel load treatments for the test. The fire was initiated and managed by the Hanford Fire Department in accordance with the HFD 2008 Annual Prescribed Fire Proposal (Ward et al. 2008). The controlled burn was conducted on the north half of the barrier, including the silt loam cover and the gravel side slope (Figure 2.13). Before starting the fire, a 3-m-wide line of fire retardant foam was applied to the buffer strip between the north and south sections of the barrier to protect the south portion of the barrier during the burn (Figure 2.14 and Figure 2.15).

The ground-fire crew used drip torches (Figure 2.16) to ignite the fire, starting at the center of the southern portion of the northern half of the barrier and working east and west along the southern portion and north, allowing the flames to carry eastward. The three members of the fire ground-crew maintained constant radio contact with the fire rigs. The fire was documented from ignition through completion using a variety of methods, including still photographs and a digital video. A video camera was mounted on top of one of the bush rigs such that the entire burn area could be viewed. During the fire, the flame height was determined using decimeter-scale flame height rods (black and white metal rods) installed outside at the edge of plots. This was accomplished by peering through the flames to the flame height rods and recording the elevation of the flame. After the main fire, plots with incomplete combustion were burned off using a drip torch. All areas were monitored until the threat of spotting had ceased. The surface was also examined to identify any mosaic patterns that are indicative of variable fire severity. The flame speed was determined by measuring the time to travel from the ignition line to the thermocouples, which were located about $3 \mathrm{~m}$ from the edge of the plot.

\subsection{Post-Burn Monitoring}

Following completion of the controlled burn, most of the pre-burn measurements were repeated. Soil samples were collected on the 3 - $\mathrm{m} \times 3$ - $\mathrm{m}(10-\mathrm{ft} \times 10$-ft) grid at various times, and the physical, hydraulic, and geochemical measurements were repeated. Water extracts (1:1) were used to measure soil $\mathrm{pH}$, electrical conductivity, and the concentrations of macro nutrients. Measurements of cation exchange capacity and specific surface area were repeated on the $<2-\mathrm{mm}(<0.08$-in.) fractions whereas water-drop penetration tests were performed on whole samples. The gravel content was determined by dry sieving. Hydraulic conductivity measurements were repeated on the 9-m $\times 9-\mathrm{m}(29.5-\mathrm{ft} \times 29.5-\mathrm{ft})$ grid using the Guelph Permeameter and Guelph tension infiltrometer methods. Near-surface moisture content and bulk density were repeated on a 3-m $\times 3-\mathrm{m}(10-\mathrm{ft} \times 10-\mathrm{ft})$ grid. Soil samples were also collected on a 12-m $\times 12$-m (39.4-in. $\times 39.4$ in.) grid to assess the seed bank remaining after the fire. 


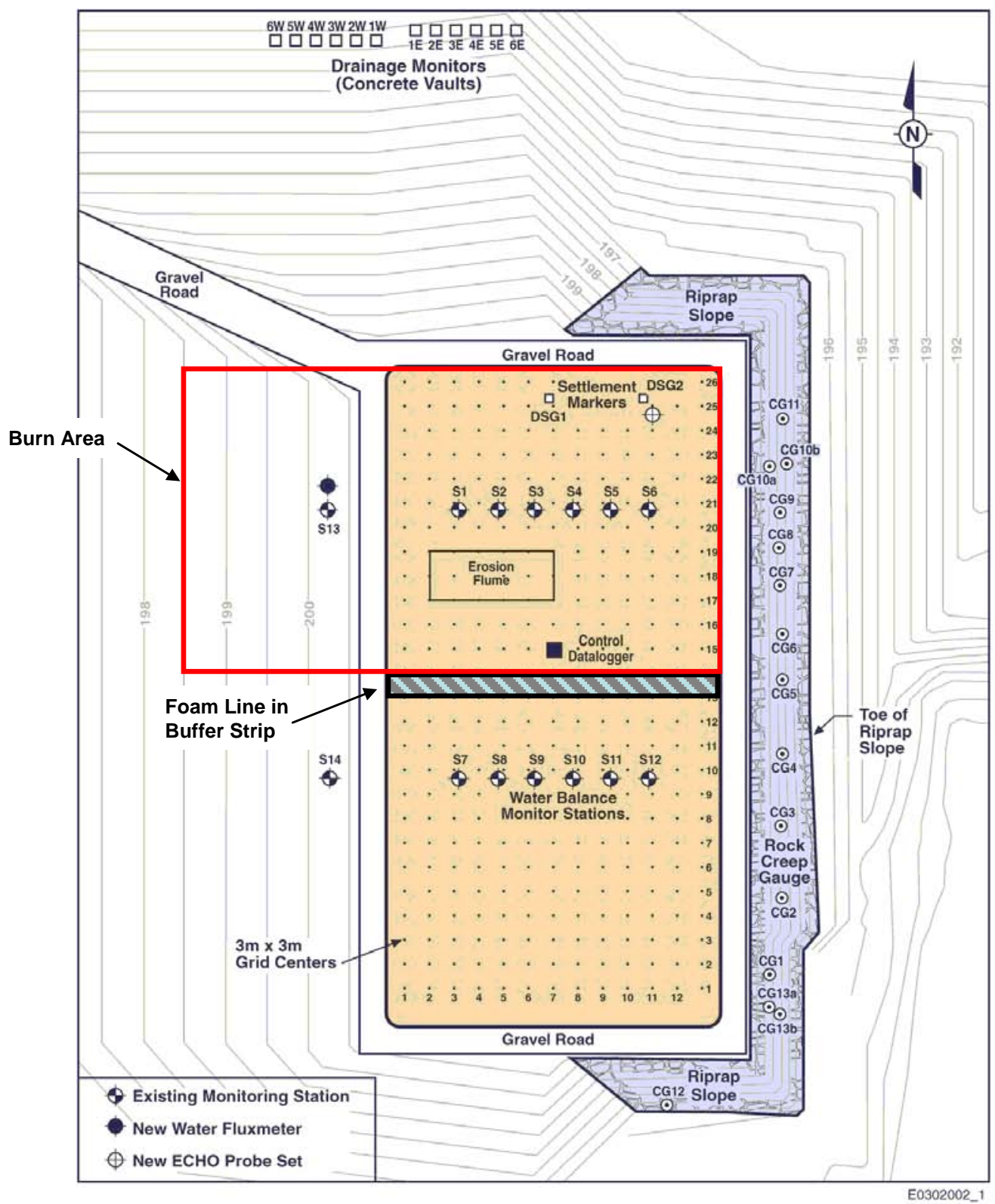

Figure 2.13. Plan View of the Barrier's Surface Showing Proposed Burn Area on the Gravel Side Slope and Silt-Loam Surface 


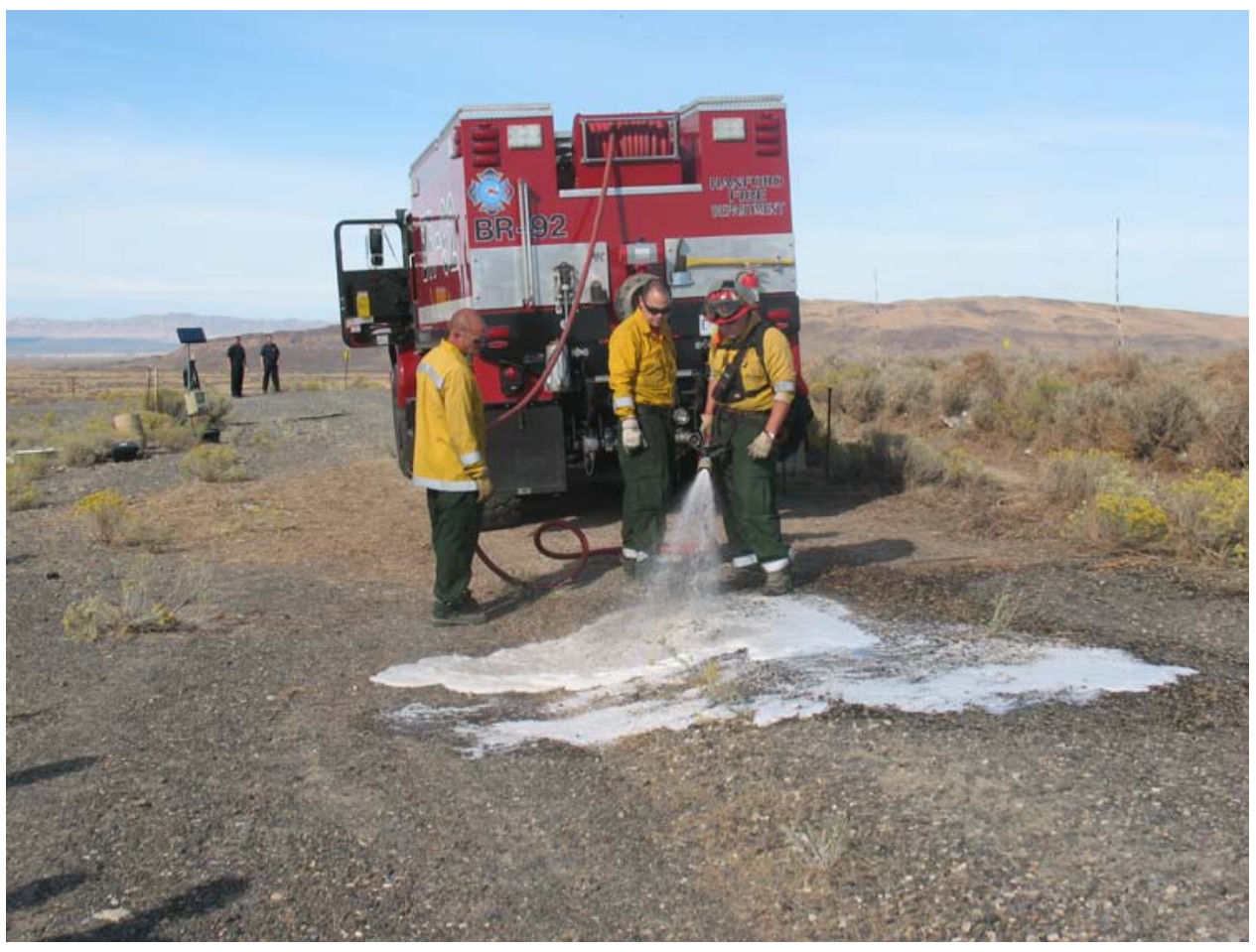

Figure 2.14. Hanford Fire Department Bush Rig Crew Making Adjustments to the Fire Retardant Foam Quality Before the Burn 


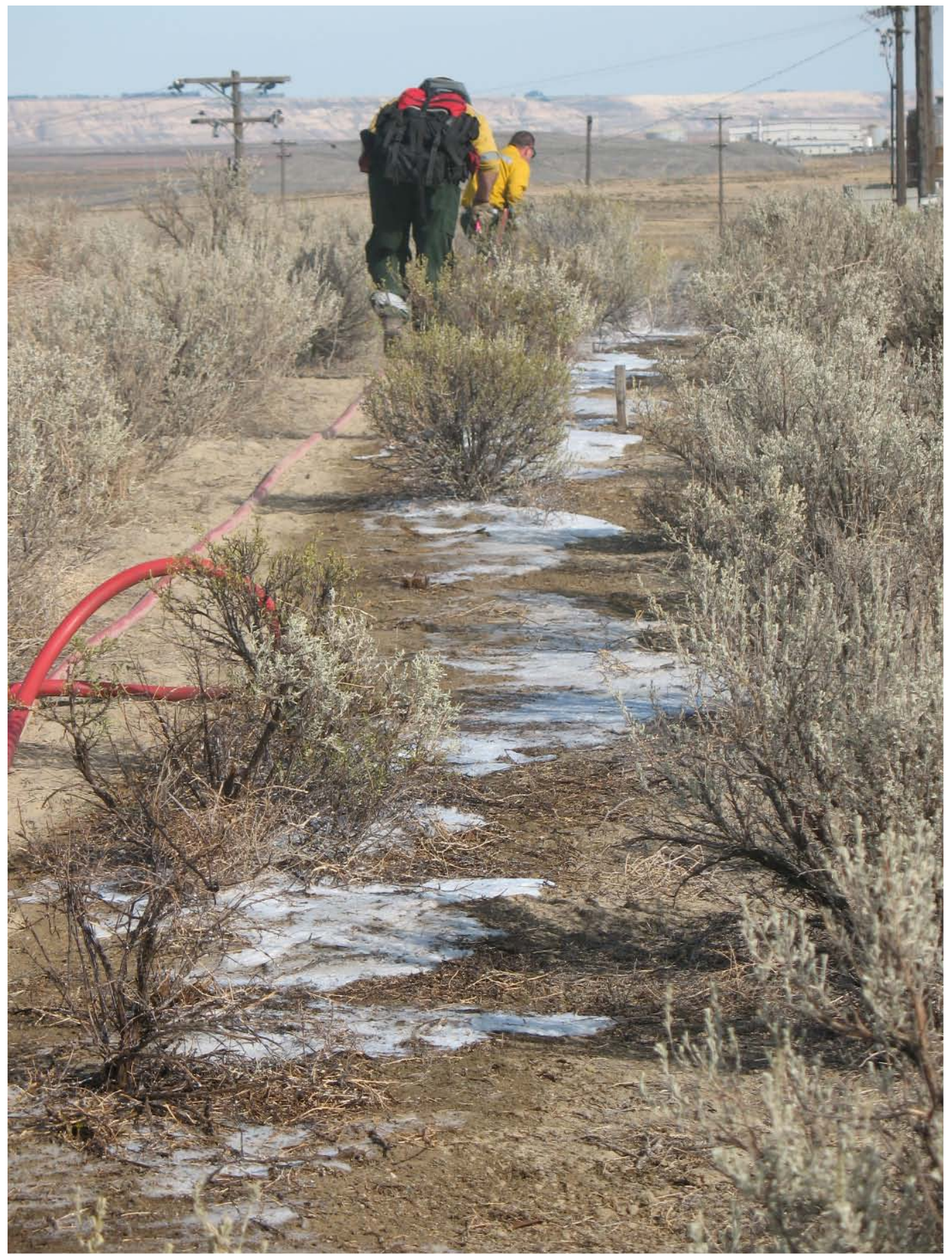

Figure 2.15. The 3-m-Wide Line of Fire Retardant Foam Applied to the Buffer Strip Between the North and South Sections of the Barrier 


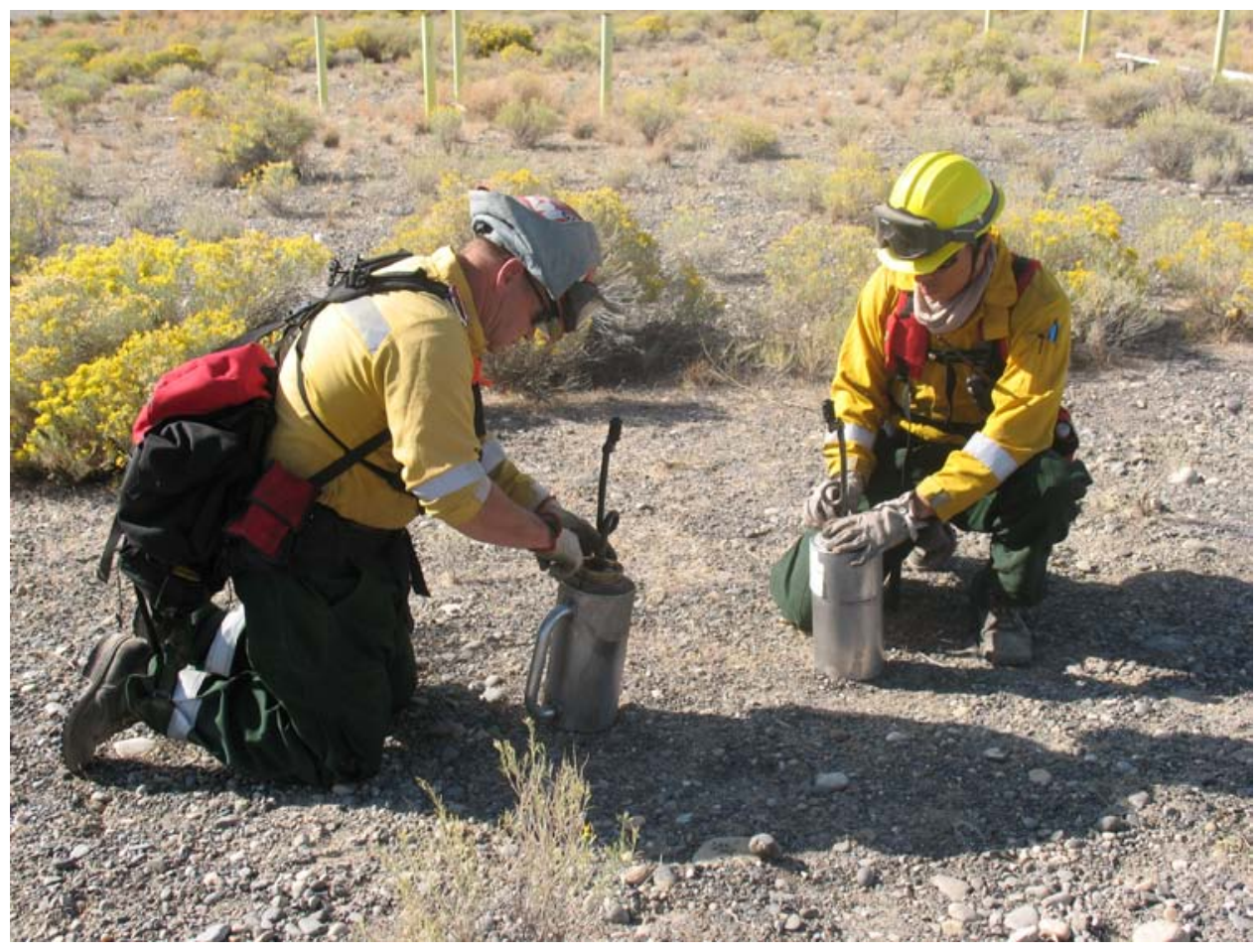

Figure 2.16. Personnel of the Hanford Fire Department Preparing Drip Torches Before Igniting the Test Plots 


\subsection{Results}

Many of the changes resulting from wildfire depend on fire severity and intensity, which in turn are controlled by a variety of other factors. Fire produces a spectrum of severities that depends on the interactions of burning, intensity, duration, fuel loading (i.e., live and dead materials), combustion type and degree of oxidation, vegetation type, fire climate, slope, topography, soil texture and moisture, soil organic matter content, burn history of the site (time since it last burned), and the area burned. Thus, the effects of fire on an engineered mixed shrub/grass ecosystem can cover a wide range of severity and will be evident both in the short term and long term. This section summarizes the results of the pre-fire characterization and the short-term effects of the fire observed between September 2008 and 1 year later in September 2009.

\subsection{Ecological Characterization}

Information on plant characteristics, small mammal diversity, and use of the barrier by mammals was collected before the controlled burn. Plant information collected included a species list for the north (formerly irrigated) section and south (formerly non-irrigated) section of the barrier. Plant information was also collected on the north and west side-slopes. Shrub height, greatest canopy diameter, and the diameter at the center of the plant perpendicular to the greatest diameter were measured on 25 shrubs each from sections of the barrier. General assessments of shrub survival, re-sprouting, and recruitment were also made. A similar type of assessment was performed at an undisturbed site located on a representative silt-loam surface at the McGee ranch to serve as a control.

\subsubsection{Pre-burn Plant Species Composition}

Plant species observed on the north half of the surface were Artemisia tridentata, Bromus tectorum, Elymus wawawaiensis, Ericameria nauseosa, Machaeranthera canescens, Poa secunda, and Salsola kali. The species richness of the entire surface (burned and unburned halves) decreased from a high of 35 species in 1997, the third year after planting, to only 12 in 2007. There were only 10 species present in 2008 (Figure 3.1). Only 7 of 14 species present in 2004 were present in 2008. Of the 5 new species on the surface in 2008, Centaurea diffusa has never been present while the other four have been observed in the past.

The dominance of $A$. tridentata on the surface may likely contribute to continued reductions in species richness on the surface. Many of the species present at the pre-burn survey were represented by only a few individuals, and some of these were only found on the edges of the barrier where there was less competition from $A$. tridentata. The reduction in the number of species on the surface is partly caused by a relatively high density of $A$. tridentata. Artemisia tridentata was by far the most common plant on the surface and comprises almost a monoculture. The condition of dominance by A. tridentata is similar to heavily grazed communities where herbaceous forbs and perennial grasses are minor (Laycock 1991). With very little $B$. tectorum present, the likely state transition is that caused by fire with the plant community recovering to a more diverse assemblage of species where A. tridentata is no longer dominant (Laycock 1991). The transpirational function of the barrier is likely to be compromised, though, after a fire and before enough vegetation is reestablished. The length of time for a more diverse plant community to re-establish is currently not known. 


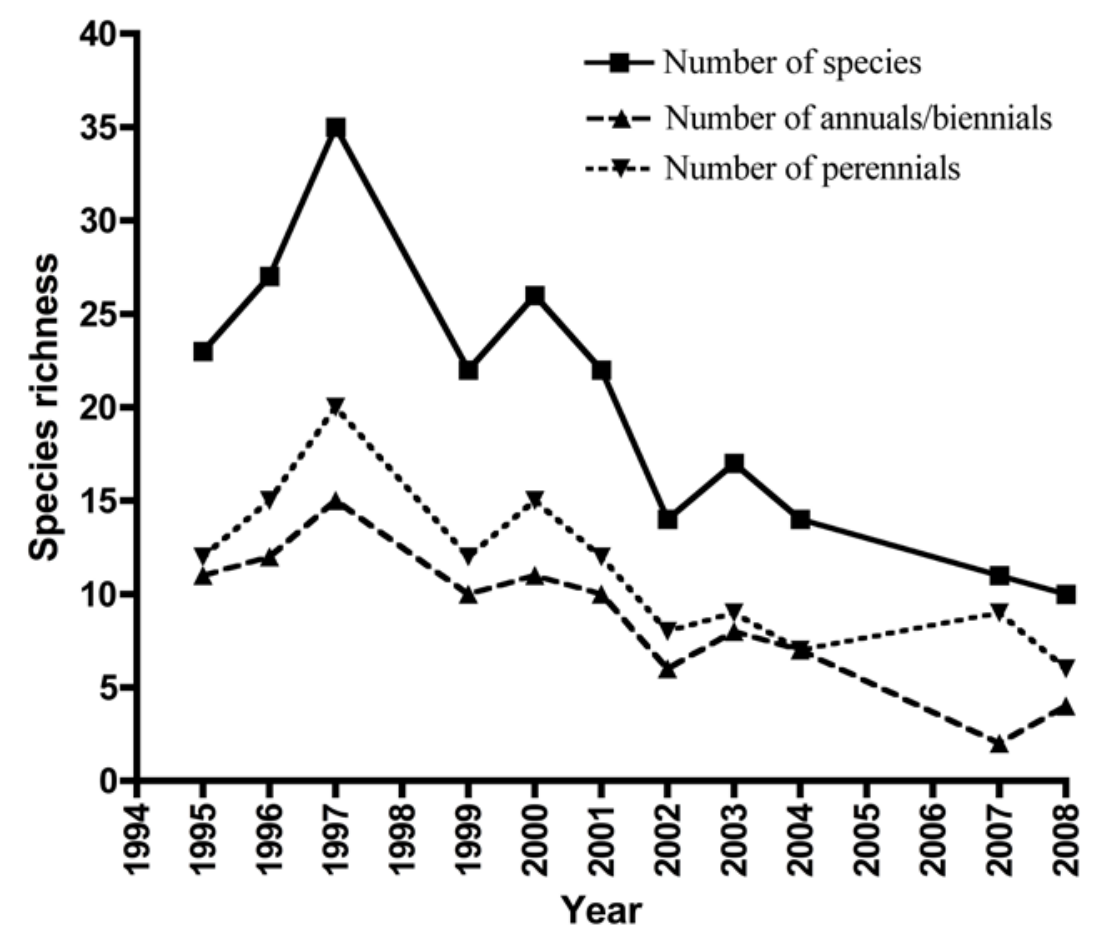

Figure 3.1. Species Richness on the Entire Barrier Surface Since 1995

The biomass was estimated across the surface by assessing $A$. tridentata and $S$. kali litter. The canopy structure of $A$. tridentata was measured and related to the harvested biomass. Measurements were taken on 18 plants covering the range of sizes on the barrier surface. Data recorded included maximum height $(z)$, maximum diameter in the longitudinal direction $(x)$, and maximum diameter in the transverse direction $(y)$. These individuals were then harvested and weighed. The relationship used to predict biomass is:

$$
Y=\alpha+\beta e^{(2 x+\delta y+\varepsilon z)}
$$

where $\alpha, \beta, \gamma, \delta$, and $\varepsilon$ are nonlinear regression parameters. The estimated parameters resulted in a highly significant predictive relationship $\left(\mathrm{r}^{2}=0.95, \mathrm{p}<0.001\right)$. The parameter values are $\alpha=-182.3 \pm 144.1, \beta=$ $129.0 \pm 100.5, \gamma=0.01239 \pm 0.006033, \delta=0.007617 \pm 0.004571$, and $\varepsilon=0.003688 \pm 0.002629$. Eightyone $A$. tridentata shrubs were measured for canopy characteristics across the burn area, resulting in an average predicted wet biomass of $1.15 \pm 0.05 \mathrm{lb}$ (522 $\pm 55 \mathrm{~g}$ ). Shrubs were counted in 84 quadrats, resulting in an average of $13.15 \pm 0.65$ shrubs in each quadrat. Thus, there were about 1894 shrubs on the surface with a total estimated wet biomass of $988 \mathrm{~kg}(2178 \mathrm{lb})$. The mean water content was $22.4 \pm$ $0.87 \%$ by weight; thus, the oven-dried biomass was $767 \mathrm{~kg}(1691 \mathrm{lb})$. There was about $383.7 \mathrm{~kg}$ (846 lb) of oven-dried shrub mass in each of the high- and low-fuel treatments on the surface. The area of the burn area is 0.32 acres ( 0.129 ha), so the mean shrub fuel load was around 5.92 tonnes/ha (2.64 tons/Ac).

The biomass of $S$. kali was determined by estimating the amount present and the amount added to the surface. The amount added to the surface was similar to amounts already present in the low-fuel treatments, but was distributed fully across the surface while that already present was clumped. The average wet mass added to the low-fuel treatment was $3.67 \mathrm{~kg}(8.1 \mathrm{lb})$ in each quadrat. The mean water 
content was $4.21 \pm 0.327 \%$, resulting in an oven-dried biomass added of $3.52 \mathrm{~kg}$ (7.76 lb). About $253.6 \mathrm{~kg}$ (559 lb) of dried mass was added to low-fuel treatment. The added fuel load was about 3.92 tonnes/ha (1.75 tons/Ac). The average wet mass added to the high fuel half was $5.51 \mathrm{~kg}(12.15 \mathrm{lb})$ in each quadrat. Thus, the dried biomass added was $5.29 \mathrm{~kg}(11.7 \mathrm{lb})$. There was about $380.7 \mathrm{~kg}(839 \mathrm{lb})$ of oven-dried mass added to the high fuel half. The added fuel was about 5.9 tonne/ha (2.63 tons/Ac).

The mass already present in the low-fuel treatments was estimated by relating the mass of added fuel that provides generally high cover of about $90 \%$ to existing cover in each quadrat. The cover was visually estimated in each quadrat. The resulting estimate was $0.63 \pm 0.08 \mathrm{~kg}(1.39 \pm 0.176 \mathrm{lb})$ in each quadrat. There was about $100 \mathrm{lb}$. In the future preset, these data in tabular format (45.4 kg) were existing in the low fuel half of the surface. The existing fuel load was about 0.695 tonne/ha $(0.31$ tons/Ac). The existing biomass on the high-fuel treatment was estimated at $1.31 \pm 0.14 \mathrm{~kg}(2.88 \pm 0.31 \mathrm{lb})$ in each quadrat. There was about $94.3 \mathrm{~kg}(207.89 \mathrm{lb})$ existing in the high-fuel treatment. The existing fuel load was about 1.457 tonne/ha ( 0.65 tons/Ac). The total fuel load on the low-fuel plots was around 10.54 tonne/ha (4.7 tons/Ac) compared to 12.8 tonne/ha (5.71 tons/Ac) on the high-fuel plots. The fuel load contributed by bunchgrasses and other plants was minor and was not used for the total-fuel-load estimate. The fuel load and plant composition are similar to that of shrub fuel type SH2 (142) in the “Moderate Load Dry Climate” used in standard fire behavior fuel models (Scott and Burgan 2005).

\subsubsection{Post-Burn Plant Species Composition}

Table 3.1 identifies vegetation species on the burned and unburned treatments of the barrier and at the two McGee Ranch analog sites. Figure 3.2 compares the total number of species on the barrier surface from 1995 to 2009. Table 3.2 lists the species on the barrier side slopes. The species richness of the plant community on the prototype Hanford barrier has dropped from 35 in 1997 to 10 in 2008 just before the fire. Nearly 1 year after the fire, species richness increased to 15 in the unburned half of the surface and increased markedly to 24 species on the burned half of the surface. Species richness at the two analog sites is essentially the same as on the unburned half of the barrier (Table 3.1). Species richness on the two side slopes was lower than in other areas (Table 3.2). Annual and biennial species are $32 \%$ of the flora in the long-term undisturbed community at the McGee Ranch, 44\% in the McGee Ranch old burn, 53\% in the unburned barrier surface, and increasing to $58 \%$ on the burned half of the barrier. The dominance of A. tridentata on the unburned half of the barrier surface may contribute to continued reductions in species richness on the surface. Similar species richness was found at the unburned McGee Ranch analog site that is also dominated by $A$. tridentata. This is in contrast to the similar richness at the burned McGee Ranch analog site, even though A. tridentata has very low cover. Factors other than dominance by A. tridentata are determinants of species richness. It is likely that the increase in species richness after fire is a short-lived consequence of fire given that the old burn at McGee Ranch had essentially the same species richness. 
Table 3.1. Plant Species Observed in 2009 on the Burned and Unburned Sections of the Barrier Plus at two McGee Ranch Analog Sites

\begin{tabular}{|c|c|c|c|c|c|}
\hline Family & Species & Barrier Burn & $\begin{array}{c}\text { Barrier } \\
\text { Unburned }\end{array}$ & $\begin{array}{c}\text { McGee Old } \\
\text { Burn } \\
\end{array}$ & $\begin{array}{c}\text { McGee } \\
\text { Unburned }\end{array}$ \\
\hline \multirow{15}{*}{ Asteraceae } & Achillea millifolium & $\mathrm{X}$ & & & \\
\hline & Artemisia tridentate & $X$ & $\mathrm{X}$ & $\mathrm{X}$ & $X$ \\
\hline & Balsamorhiza careyana & & & $\mathrm{X}$ & \\
\hline & Centaurea diffusa & $\mathrm{X}$ & $\mathrm{X}$ & $\mathrm{X}$ & \\
\hline & Chrysothamnus viscidiflorus & $\mathrm{X}$ & $\mathrm{X}$ & & \\
\hline & Crepis atribarba & & & & $\mathrm{X}$ \\
\hline & Ericameria nauseosa & $\mathrm{X}$ & $\mathrm{X}$ & $\mathrm{X}$ & \\
\hline & Erigeron filifolius & & & & $\mathrm{X}$ \\
\hline & Erigeron piperianus & & & & $\mathrm{X}$ \\
\hline & Erigeron poliospermus & & & & $X$ \\
\hline & Helianthus cusickii & & & $\mathrm{X}$ & $\mathrm{X}$ \\
\hline & Lactuca serriola & $\mathrm{X}$ & & & \\
\hline & Machaeranthera canescens & $\mathrm{X}$ & $\mathrm{X}$ & $X$ & $\mathrm{X}$ \\
\hline & Stephanomeria paniculata & $\mathrm{X}$ & & & \\
\hline & Tragopogon dubius & $X$ & & $\mathrm{X}$ & \\
\hline Boraginaceae & Amsinckia lycopsoides & $\mathrm{X}$ & $\mathrm{X}$ & & \\
\hline \multirow{2}{*}{ Brassicaceae } & Descurainia pinnata & $X$ & & $\mathrm{X}$ & $X$ \\
\hline & Sisymbrium altissimum & $\mathrm{X}$ & $\mathrm{X}$ & $\mathrm{X}$ & \\
\hline \multirow{3}{*}{ Chenopodiaceae } & Chenopodium leptophyllum & $\mathrm{X}$ & & & \\
\hline & Grayia spinosa & & & & $\mathrm{X}$ \\
\hline & Salsola kali & $\mathrm{X}$ & $\mathrm{X}$ & $\mathrm{X}$ & $X$ \\
\hline \multirow{2}{*}{ Fabaceae } & Astragalus caricinus & $\mathrm{X}$ & & & \\
\hline & Melilotus officinalis & $X$ & & & \\
\hline Geraniaceae & Erodium cicutarium & $\mathrm{X}$ & $\mathrm{X}$ & & \\
\hline Malvaceae & Sphaeralcea munroana & & & $\mathrm{X}$ & $\mathrm{X}$ \\
\hline
\end{tabular}


Table 3.1 (contd)

\begin{tabular}{|c|c|c|c|c|c|}
\hline Family & Species & Barrier Burn & $\begin{array}{c}\text { Barrier } \\
\text { Unburned }\end{array}$ & $\begin{array}{c}\text { McGee Old } \\
\text { Burn }\end{array}$ & $\begin{array}{c}\text { McGee } \\
\text { Unburned }\end{array}$ \\
\hline \multirow{8}{*}{ Poaceae } & Achnatherum hymenoides & & & $\mathrm{X}$ & $\mathrm{X}$ \\
\hline & Bromus tectorum & $\mathrm{X}$ & $\mathrm{X}$ & $\mathrm{X}$ & $\mathrm{X}$ \\
\hline & Elymus elymoides & & & $\mathrm{X}$ & $\mathrm{X}$ \\
\hline & Elymus wawawaiensis & $X$ & $\mathrm{X}$ & & \\
\hline & Poa ampla & $\mathrm{X}$ & $\mathrm{X}$ & & \\
\hline & Poa bulbosa & $X$ & $\mathrm{X}$ & & \\
\hline & Poa secunda & $\mathrm{X}$ & $\mathrm{X}$ & $\mathrm{X}$ & $\mathrm{X}$ \\
\hline & Vulpia microstachys & $X$ & $\mathrm{X}$ & & $\mathrm{X}$ \\
\hline Polemoniaceae & Phlox longifolia & & & $\mathrm{X}$ & \\
\hline \multirow[t]{2}{*}{ Verbenaceae } & Verbena bracteata & $\mathrm{X}$ & & & \\
\hline & Total Number of Species Present & 24 & 15 & 16 & 16 \\
\hline
\end{tabular}

Table 3.2. Plant Species Observed in 2009 on the West and North Side-Slopes of the Barrier

\begin{tabular}{|c|c|c|c|}
\hline Family & Species & West Slope & North Slope \\
\hline \multirow{7}{*}{ Asteraceae } & Achillea millefolium & & $\mathrm{X}$ \\
\hline & Artemisia tridentata & $\mathrm{X}$ & $\mathrm{X}$ \\
\hline & Ericameria nauseosa & $\mathrm{X}$ & $\mathrm{X}$ \\
\hline & Centaurea diffusa & $\mathrm{X}$ & \\
\hline & Chrysothamnus viscidiflorus & $\mathrm{X}$ & $\mathrm{X}$ \\
\hline & Lactuca serriola & $\mathrm{X}$ & \\
\hline & Machaeranthera canescens & $\mathrm{X}$ & $\mathrm{X}$ \\
\hline Carhophyllaceae & Holosteum umbellatum & $\mathrm{X}$ & $\mathrm{X}$ \\
\hline Chenopodiacea & Salsola kali & $\mathrm{X}$ & \\
\hline Fabaceae & Astragalus caricinus & & $\mathrm{X}$ \\
\hline Geraniaceae & Erodium cicutarium & $\mathrm{X}$ & \\
\hline \multirow{5}{*}{ Poaceae } & Bromus tectorum & $\mathrm{X}$ & $\mathrm{X}$ \\
\hline & Elymus wawawaiensis & $\mathrm{X}$ & $\mathrm{X}$ \\
\hline & Poa bulbosa & $\mathrm{X}$ & $\mathrm{X}$ \\
\hline & Poa secunda & $\mathrm{X}$ & $\mathrm{X}$ \\
\hline & Total Number of Species Present: & 13 & 11 \\
\hline
\end{tabular}




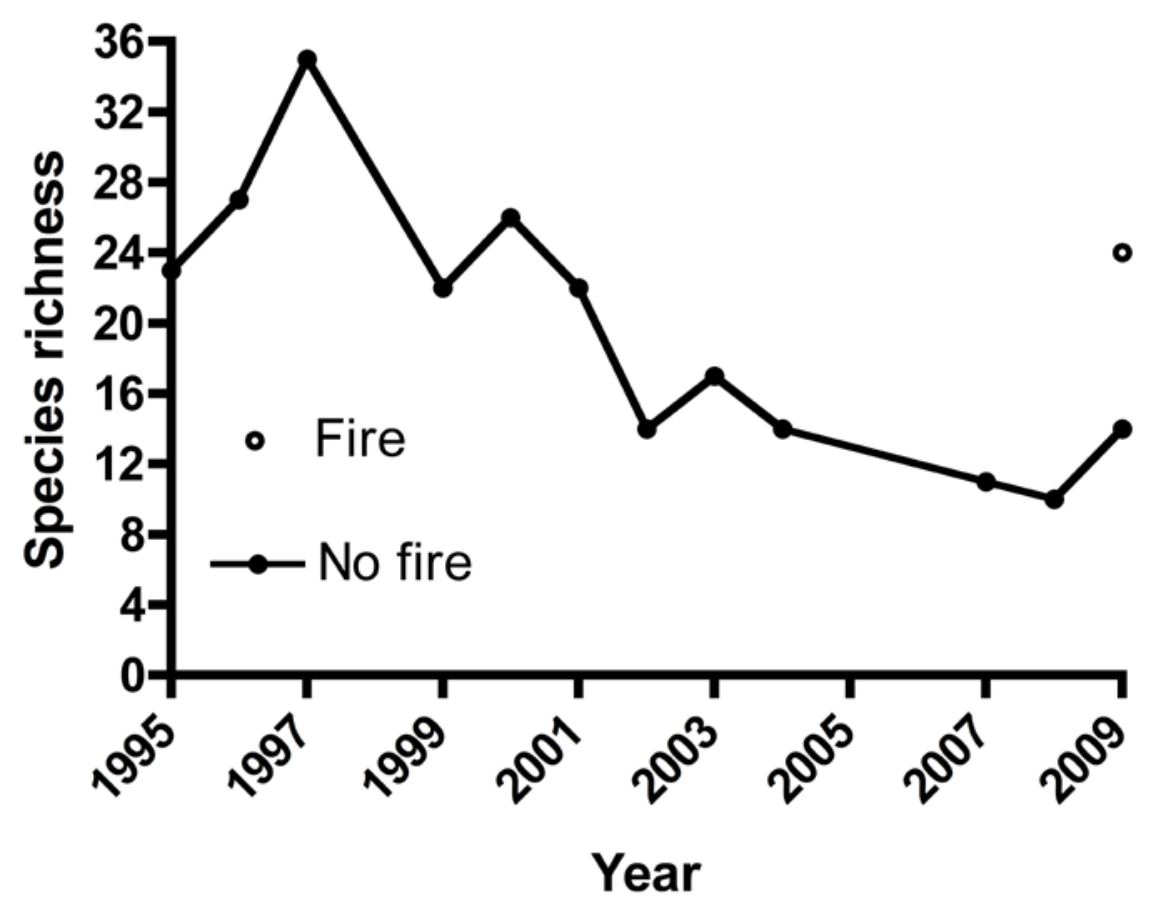

Figure 3.2. Temporal Variation in the Number of Species on the Prototype Hanford Barrier from Inception Through September 2009, 1 Year After the Fire

\subsubsection{Soil Cryptogram}

Soil cryptogam composition (Table 3.3) varied widely at the four study sites. There were no soil cryptogams observed on the burned surface of the barrier. There was only one soil lichen found at the McGee Ranch old fire site. The unburned half of the barrier surface had seven species, and the unburned McGee Ranch site had 12 species.

\subsubsection{Shrub Density}

Pre-burn shrub density was determined by counting all live sagebrush functional plants and all live Ericameria nauseosa plants in 84 of the $9 \mathrm{~m}^{2}$ quadrats. Sagebrush density was $0.94 \pm 0.075$ plants $\mathrm{m}^{-2}$. Ericameria nauseosa density was $0.0251 \pm 0.00605$ plants $\mathrm{m}^{-2}$. Sagebrush is the dominant shrub on the surface. The plant height was measured on all sagebrush plants in the same plots used for density. The height of sagebrush was consistently larger in all quadrats except those in the $25^{\text {th }}$ row near the north side of the barrier (Figure 3.3). Sagebrush on the north edge of the burn area was much shorter than in the interior of the burn area. This is because there is significantly more recruitment along the north edge of the burn area where there is less competition.

Cover types were compared using midpoints of cover classes to compute means. The mean cover classes for the formerly irrigated (north) portion of the silt-loam plots to be burned is shown in Figure 3.4. Grass cover was significantly greater than zero, but significantly less than shrub cover and other classes. Soil cryptogam cover was the same as soil cover. The ground cover was used to estimate the amount of 
fuel. Percent cover was estimated for shrubs, Salsola kali, grasses, forbs, and litter. These cover estimates were summed and in some cases exceeded $100 \%$. The spatial distribution of percent cover, as shown in Figure 3.5, was quite variable. The existing fuel before the adding $S$. kali to the surface was determined visually.

Table 3.3. Lichens and Mosses on the Barrier and at the Burned and Unburned McGee Ranch

\begin{tabular}{|c|c|c|c|}
\hline & $\begin{array}{l}\text { Barrier } \\
\text { Unburned }\end{array}$ & $\begin{array}{l}\text { McGee } \\
\text { Old Burn }\end{array}$ & $\begin{array}{l}\text { McGee } \\
\text { Unburned }\end{array}$ \\
\hline \multicolumn{4}{|l|}{ Lichens } \\
\hline Acarospora schleicheri (Ach.) A. Massal. & & $\mathrm{X}$ & \\
\hline Caloplaca tominii Savicz & $\mathrm{X}$ & & $\mathrm{X}$ \\
\hline Candelaria concolor (Dickson) Stein & $\mathrm{X}$ & & \\
\hline Candelariella terrigena Rasanen & $\mathrm{X}$ & & $\mathrm{X}$ \\
\hline Cladonia pyxidata (L.) Hoffm. & & & $\mathrm{X}$ \\
\hline Lecanora muralis (Schreb.) Rabenh. & & & $\mathrm{X}$ \\
\hline Physconia enteroxantha (Nyl.) Poelt & & & $\mathrm{X}$ \\
\hline Physconia isidiigera (Zahlbr.) Essl. & $\mathrm{X}$ & & $\mathrm{X}$ \\
\hline Psora globifera (Ach.) Mass. & & & $\mathrm{X}$ \\
\hline Psora luridella (Tuck.) Fink & $\mathrm{X}$ & & $\mathrm{X}$ \\
\hline Trapeliopsis steppica McCune \& Camacho & & & $\mathrm{X}$ \\
\hline \multicolumn{4}{|l|}{ Mosses } \\
\hline Bryum argenteum Hedw. & & & $\mathrm{X}$ \\
\hline Bryum cf caespiticium Hedw. (sterile) & $\mathrm{X}$ & & $\mathrm{X}$ \\
\hline Syntrichia ruralis var. papillosissima (Copp.) Loeske. & $\mathrm{X}$ & & $\mathrm{X}$ \\
\hline
\end{tabular}

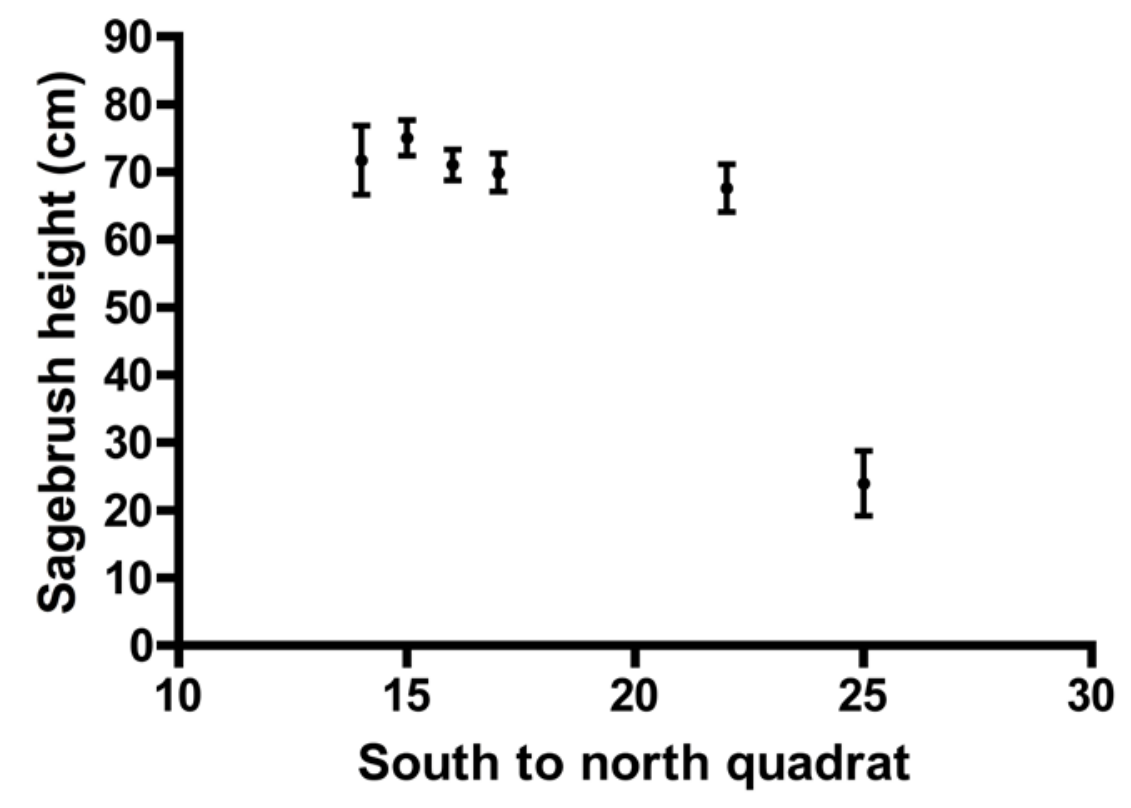

Figure 3.3. Mean Height of Sagebrush Plants in Quadrats from the South Side of the Burn Area to the North Side 
Post-burn shrub density varied among the four study sites (Table 3.4). The Artemisia tridentata density was very low and was the same after the barrier burn and at the McGee old burn site. The density was significantly greater at the unburned area on the barrier than at the McGee Ranch unburned analog site. Ericameria nauseosa established in significant, but low numbers after the fire on the barrier surface. This and other shrubs were present only in low numbers (Table 3.4).

Shrub density varied by size/age class among the four sites (Table 3.5). At the McGee unburned site, about $79 \%$ of the shrubs were old while $96 \%$ were old on the barrier unburned site. This indicates that the shrubs, while reproducing, are not reproducing at the rate as those found at the mature plant community. The shrubs in the unburned half of the barrier likely will die faster than they are recruited until the density of large shrubs is closer to that in the mature community. When density has been sufficiently reduced, then it is likely that the $A$. tridentata population will achieve a more natural size/age distribution. The population distribution at the McGee old burn has 32\% of individuals that are large and/or old. This distribution may be partly a consequence of an incomplete burn, leaving a small number of old individuals. Shrubs were not cut to age them, but were assumed to be old. After the burn on the barrier surface, a significant number of shrubs germinated from the seed bank and/or from seed that arrived at the site. There was evidence of A. tridentata in the seed bank, so it is likely that those found on the burned barrier surface are from the seed bank. Artemisia tridentata seed is not wind-borne. In contrast, while $88 \%$ of the new shrubs on the burned barrier surface were E. nauseosa, we found none in the seed bank. If they were in the seed bank, they may not have had the appropriate conditions to germinate. It is possible that these new recruits arrived from nearby plants that released wind-borne seed after the fire. While there are few E. nauseosa plants in the adjacent unburned barrier surface, there are numerous shrubs on the adjacent side slopes that can be the source of the new recruits on the burned surface.

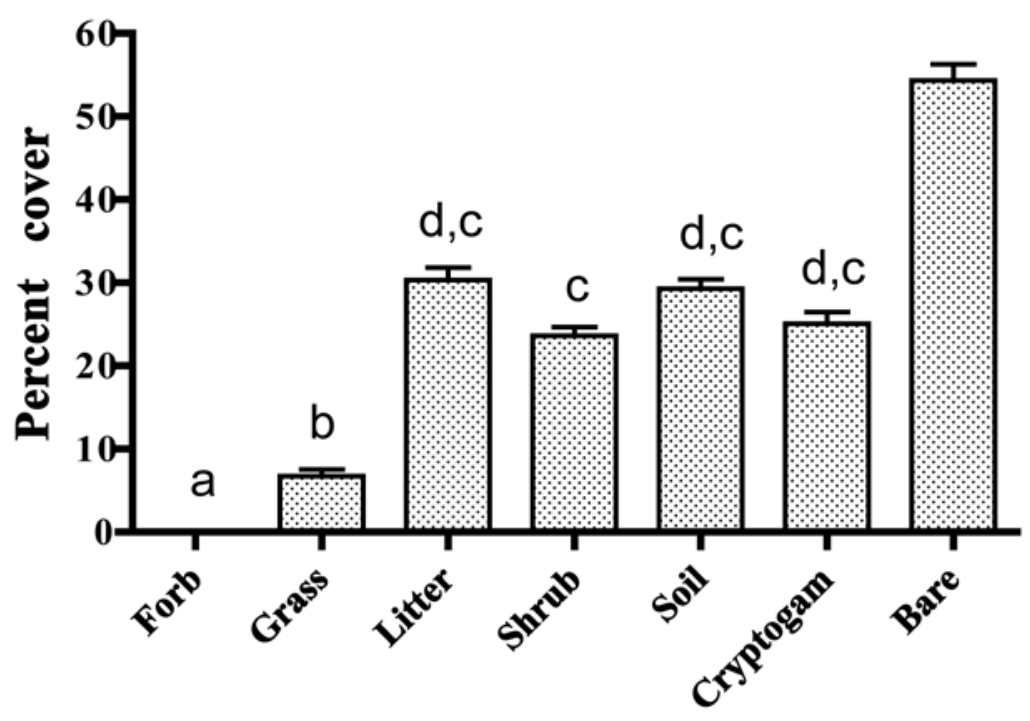

\section{Cover type}

Figure 3.4. Mean Cover on Formerly Irrigated (North) Half of the Barrier Before the Fire. Error bars of one standard error of the mean $(n=144)$. Different letters indicate significant differences. 
Table 3.4. Mean Shrub Density (plants $\mathrm{m}^{-2}$ ) \pm 1 Standard Error of the Mean

\begin{tabular}{lcccc}
\hline \multicolumn{1}{c}{ Site } & Barrier Burned & Barrier Unburned & McGee Old Burn & McGee Unburned \\
\hline $\begin{array}{l}\text { Artemisia } \\
\text { tridentate }\end{array}$ & $0.0146 \pm 0.00539 \mathrm{a}$ & $0.77 \pm 0.0121 \mathrm{~b}$ & $0.0147 \pm 0.00308 \mathrm{a}$ & $0.437 \pm 0.0331 \mathrm{c}$ \\
$\begin{array}{l}\text { Ericameria } \\
\text { nauseosa }\end{array}$ & $0.113 \pm 0.0127 \mathrm{a}$ & $0.00386 \pm 0.00202 \mathrm{~b}$ & $0.00125 \pm 0.00051 \mathrm{~b}$ & 0 \\
$\begin{array}{l}\text { Chrysothamnus } \\
\text { viscidiflorus }\end{array}$ & 0 & $0.0107 \pm 0.00609$ & 0 & 0 \\
\begin{tabular}{l} 
Grayia spinosa \\
\hline
\end{tabular} & 0 & 0 & 0 & $0.00126 \pm 0.00126$ \\
\hline
\end{tabular}

Table 3.5. Mean size/age Density (plants $\mathrm{m}^{-2}$ ) \pm 1 Standard Error of the Mean of A. Tridentata at the Four Study Sites

\begin{tabular}{lllll}
\hline \multicolumn{1}{c}{ Site } & & & & \\
Size/Age Class & Barrier Burn & Barrier Unburned & McGee Old Burn & McGee Unburned \\
\hline Large/old & 0 & $0.743 \pm 0.0104$ & $0.00469 \pm 0.00139$ & $0.344 \pm 0.0304$ \\
Mid-size & 0 & $0.027 \pm 0.00712$ & $0.00781 \pm 0.00164$ & $0.0688 \pm 0.0125$ \\
Small/young & $0.0146 \pm 0.00539$ & 0 & $0.00218 \pm 0.00148$ & $0.0238 \pm 0.00615$ \\
\hline
\end{tabular}

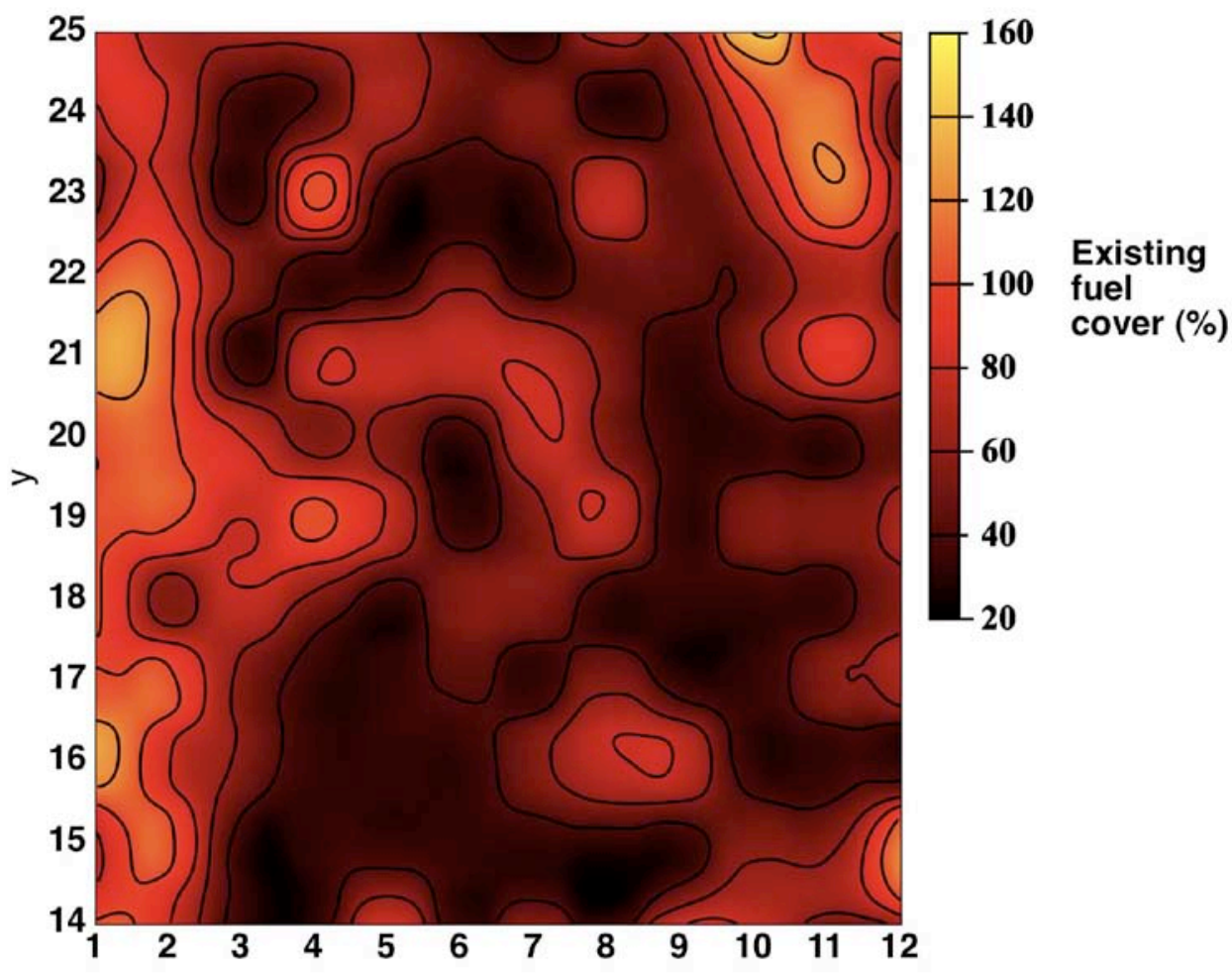

Figure 3.5. Cover of Existing Fuel Before Adding Imported Salsola Kali to the Barrier Surface 


\subsubsection{Ground Cover}

Figure 3.6 shows a photograph of the southern unburned section of the barrier in 2009, 15 years after establishment of the vegetative cover. As is evident from the photograph, the ground cover is dominated by shrubs with Artemisia tridentata accounting for $30 \%$ of the cover and grass accounting for $2 \%$. Figure 3.7 shows a photograph of the vegetative cover on the north burned section 11 months after the controlled burn. The vegetative cover at this stage is dominated by forbs (24.7\%) and grasses (4\%) with Salsola kali accounting for $19.5 \%$ of the total cover. The vegetative cover of the unburned mature community at the McGee Ranch analog site is depicted in Figure 3.8. At this site, the ground cover is mostly by shrubs (22\%), with Artemisia tridentata being dominant, and grass (23\%) with Poa secunda accounting for $15.4 \%$. The old burned plant community at the McGee Ranch site is depicted in Figure 3.9. This analog site is mostly grasses (58.9\%) with Poa secunda accounting for some $18 \%$ whereas Bromus Tectorum accounts for 39.4\%.

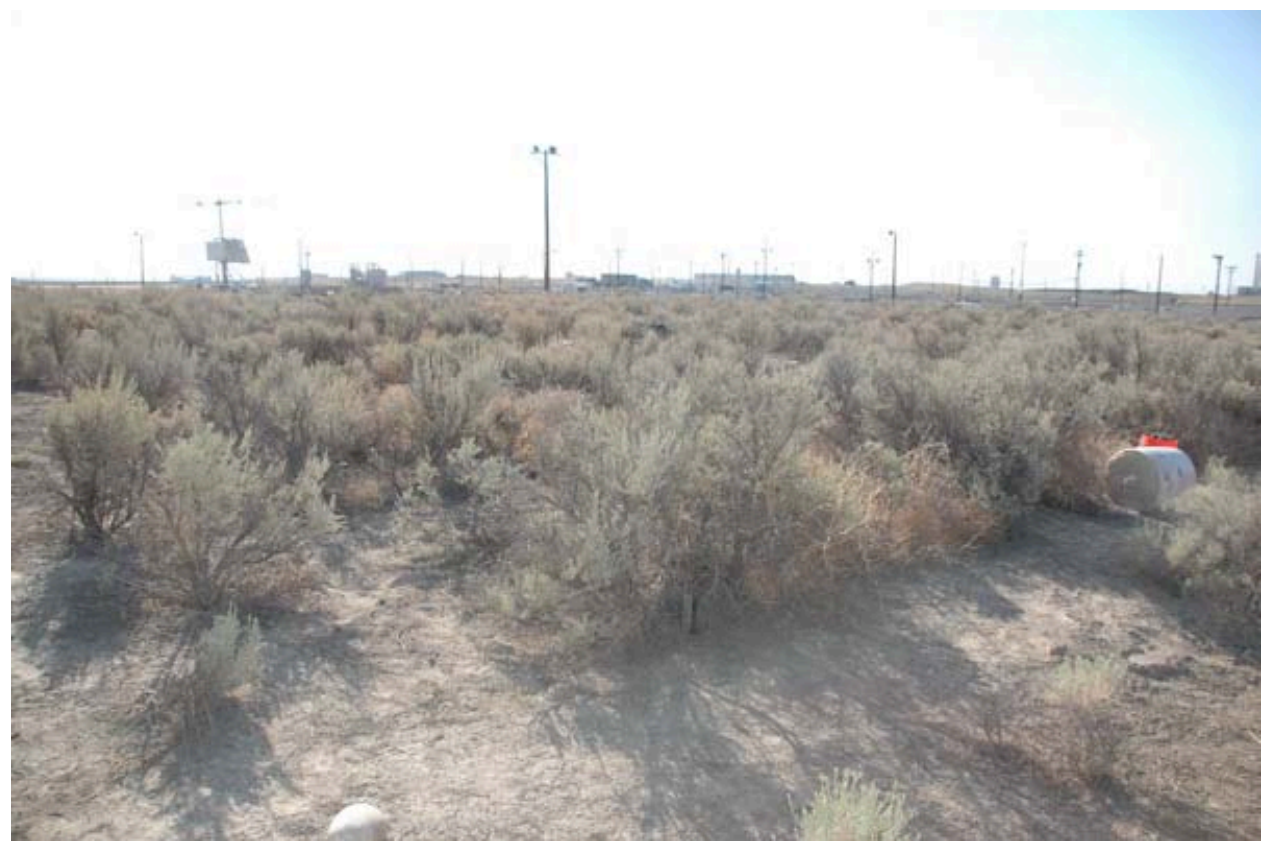

Figure 3.6. Unburned Section of Barrier Dominated by Artemisia tridentata in 2009, 15 Years After Establishment

The mean, median, and mode cover classes for each cover type in the burned and unburned treatments of the barrier are in Table 3.6 through Table 3.9. The ranges are the cover classes as defined by Daubenmire (1959). Nearly 1 year after the fire, the burned section now has the same cover of grasses as the unburned section. Shrub cover in the burned section is now much lower than in the unburned section. Litter is now lower in the burned section compared with the unburned section. Bare ground cover is now higher in the burned section compared with the unburned section. Cover values are provided for all species and other cover categories in Table 3.10 for the burned and unburned halves of the barrier surface and for the two McGee Ranch analog sites. Grass cover is very low on the barrier for the burned and unburned halves, which is in contrast to the much higher grass cover of the two McGee Ranch sites. Shrub cover is much lower in the two burned areas than in the unburned areas. Shrub cover 
in the McGee Ranch unburned area is lower than that in the unburned area on the barrier. Forb cover is similar in the two burned areas and higher than in the unburned areas.

Soil cryptogam cover does not exist on the burned half of the barrier, is low in the McGee Ranch burned area, and is much higher in the unburned areas on the barrier and at McGee Ranch. Litter cover is very low in the barrier burned area increasing in the McGee Ranch unburned area and becoming about $50 \%$ in the barrier unburned (mostly S. kali) and McGee Ranch burned areas. Cover on the north and west side slopes was relatively uniform; thus, the data were combined (Figure 3.10). Rock cover was much greater than cover of other classes while the cover of shrubs and grasses (mostly bunchgrasses) were similar.

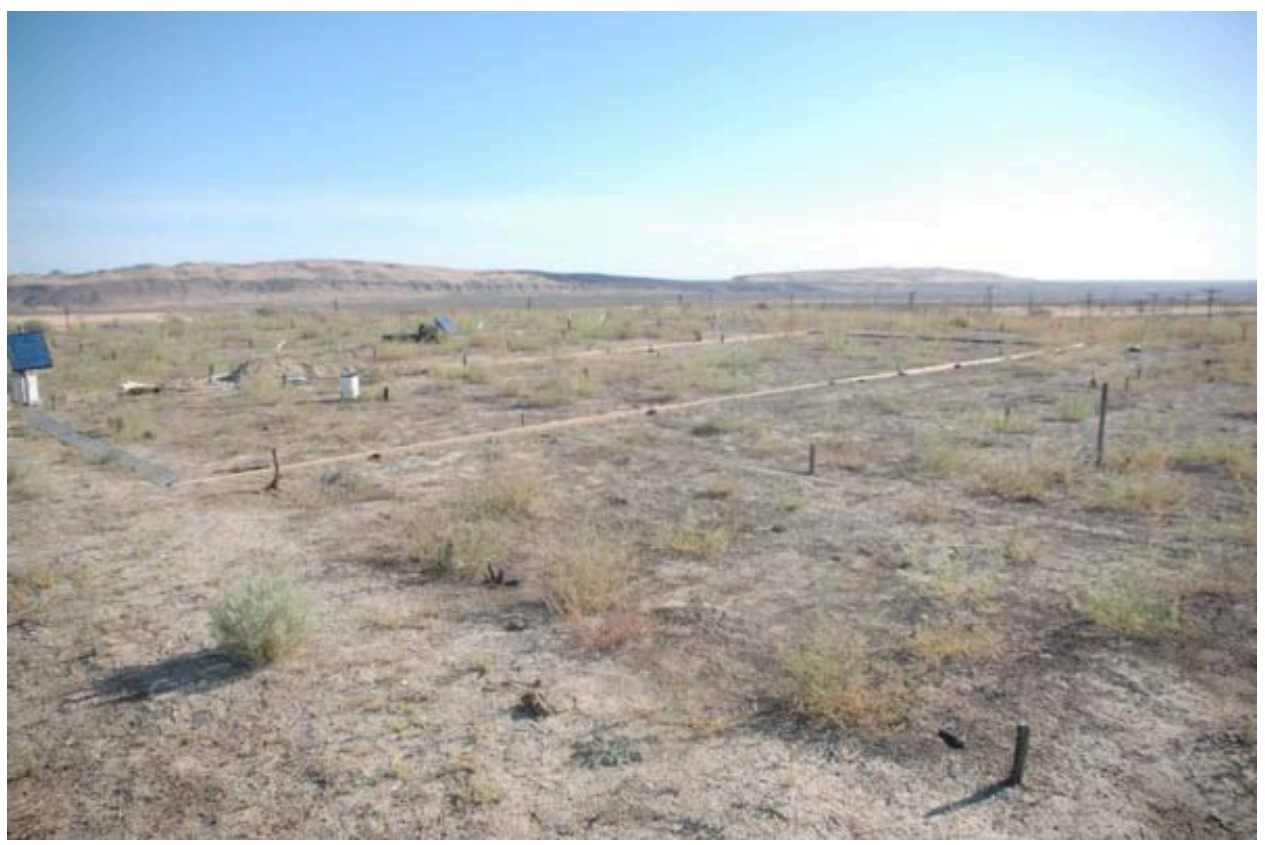

Figure 3.7. Vegetative Cover on the Burned Half of the Barrier Surface 11 Months After the Fire. Most of the Green Vegetation is Salsola kali. 


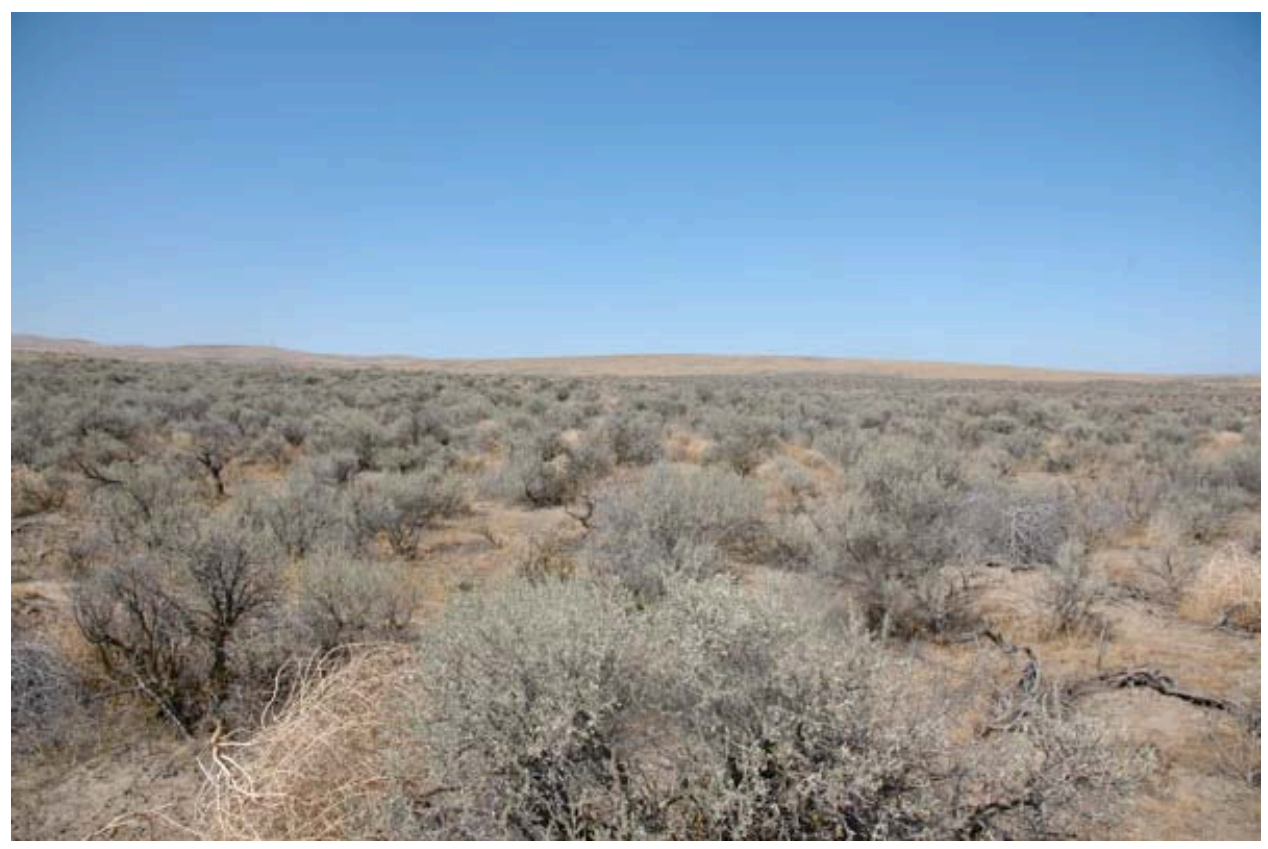

Figure 3.8. Unburned Mature Plant Community at the McGee Ranch Site

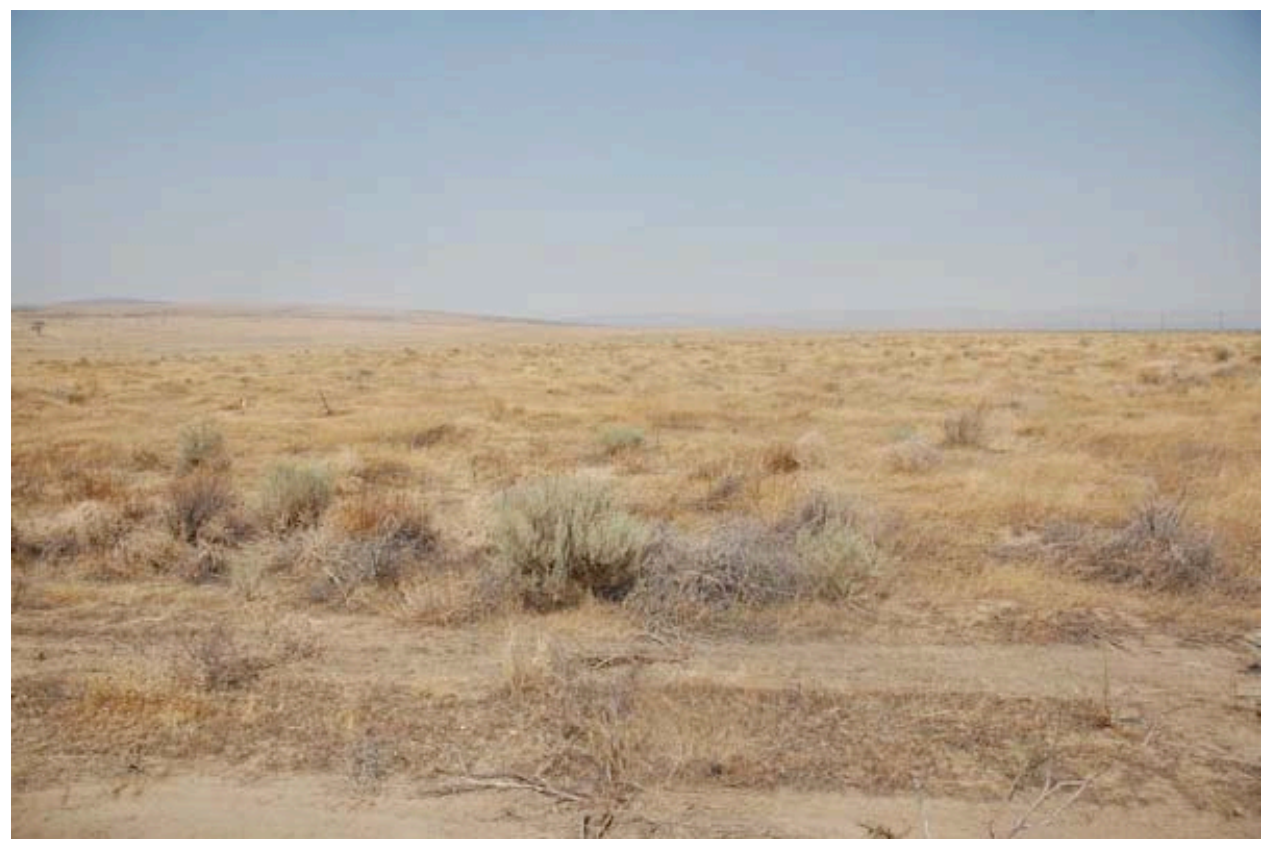

Figure 3.9. Old Burned Plant Community at the McGee Ranch Site 
Table 3.6. Median, Mode, and Mean Percent Cover Classes Ranges for Grass

\begin{tabular}{|c|c|c|c|c|c|c|}
\hline \multicolumn{2}{|c|}{ Cover Class } & \multirow{2}{*}{ Treatment } & \multirow{2}{*}{$\begin{array}{c}\text { Water Year } \\
1996\end{array}$} & \multirow{2}{*}{$\frac{\text { Median }}{25-50}$} & \multirow{2}{*}{$\frac{\text { Mode }}{5-25}$} & \multirow{2}{*}{$\frac{\text { Mean }}{-}$} \\
\hline \multirow{20}{*}{\multicolumn{2}{|c|}{ Grass }} & & & & & \\
\hline & & \multirow{9}{*}{ Burned } & 1997 & $50-75$ & $50-75$ & - \\
\hline & & & 1999 & $75-95$ & $75-95$ & $50-75$ \\
\hline & & & 2000 & $75-95$ & $75-95$ & $50-75$ \\
\hline & & & 2001 & $75-95$ & $75-95$ & $25-50$ \\
\hline & & & 2002 & $5-25$ & $5-25$ & $5-25$ \\
\hline & & & 2003 & $5-25$ & $5-25$ & $5-25$ \\
\hline & & & 2004 & $5-25$ & $5-25$ & $25-50$ \\
\hline & & & 2007 & $0-5$ & $0-5$ & $5-25$ \\
\hline & & & 2009 & $0-5$ & $0-5$ & $0-5$ \\
\hline & & \multirow{10}{*}{ Unburned } & 1996 & $5-25$ & $5-25$ & - \\
\hline & & & 1997 & $25-50$ & $25-50$ & - \\
\hline & & & 1999 & $25-50$ & $25-50$ & $25-50$ \\
\hline & & & 2000 & $5-25$ & $5-25$ & $25-50$ \\
\hline & & & 2001 & $5-25$ & $5-25$ & $5-25$ \\
\hline & & & 2002 & $0-5$ & $0-5$ & $0-5$ \\
\hline & & & 2003 & $5-25$ & $0-5$ & $5-25$ \\
\hline & & & 2004 & $0-5$ & $0-5$ & $5-25$ \\
\hline & & & 2007 & $0-5$ & $0-5$ & $0-5$ \\
\hline & & & 2009 & $0-5$ & $0-5$ & $0-5$ \\
\hline Class & 1 & 2 & 3 & 4 & 5 & 6 \\
\hline Percent Cover & 0 to 5 & 5 to 25 & 25 to 50 & 50 to 75 & 75 to 95 & 95 to 100 \\
\hline Midpoint & 2.5 & 15 & 37.5 & 62.5 & 85 & 97.5 \\
\hline
\end{tabular}


Table 3.7. Median, Mode, and Mean Percent Cover Classes Ranges for Shrubs

\begin{tabular}{|c|c|c|c|c|c|c|}
\hline \multicolumn{2}{|c|}{ Cover Class } & \multirow{2}{*}{ Treatment } & \multirow{2}{*}{$\begin{array}{c}\text { Water Year } \\
1996\end{array}$} & \multirow{2}{*}{$\frac{\text { Median }}{0-5}$} & \multirow{2}{*}{$\frac{\text { Mode }}{0-5}$} & \multirow{2}{*}{$\frac{\text { Mean }}{-}$} \\
\hline \multirow{20}{*}{\multicolumn{2}{|c|}{ Shrub }} & & & & & \\
\hline & & \multirow{9}{*}{ Burned } & 1997 & $25-50$ & $25-50$ & - \\
\hline & & & 1999 & $25-50$ & $25-50$ & $25-50$ \\
\hline & & & 2000 & $50-75$ & $50-75$ & $25-50$ \\
\hline & & & 2001 & $25-50$ & $25-50$ & $25-50$ \\
\hline & & & 2002 & $25-50$ & $25-50$ & $25-50$ \\
\hline & & & 2003 & $25-50$ & $25-50$ & $25-50$ \\
\hline & & & 2004 & $25-50$ & $25-50$ & $25-50$ \\
\hline & & & 2007 & $25-50$ & $25-50$ & $25-50$ \\
\hline & & & 2009 & $0-5$ & $0-5$ & $0-5$ \\
\hline & & \multirow{10}{*}{ Unburned } & 1996 & $0-5$ & $0-5$ & - \\
\hline & & & 1997 & $25-50$ & $25-50$ & - \\
\hline & & & 1999 & $25-50$ & $25-50$ & $25-50$ \\
\hline & & & 2000 & $25-50$ & $25-50$ & $25-50$ \\
\hline & & & 2001 & $25-50$ & $25-50$ & $25-50$ \\
\hline & & & 2002 & $5-25$ & $5-25$ & $5-25$ \\
\hline & & & 2003 & $25-50$ & $25-50$ & $25-50$ \\
\hline & & & 2004 & $25-50$ & $25-50$ & $25-50$ \\
\hline & & & 2007 & $25-50$ & $25-50$ & $25-50$ \\
\hline & & & 2009 & $25-50$ & $25-50$ & $25-50$ \\
\hline Class & 1 & 2 & 3 & 4 & 5 & 6 \\
\hline Percent Cover & 0 to 5 & 5 to 25 & 25 to 50 & 50 to 75 & 75 to 95 & 95 to 100 \\
\hline Midpoint & 2.5 & 15 & 37.5 & 62.5 & 85 & 97.5 \\
\hline
\end{tabular}


Table 3.8. Median, Mode, and Mean Percent Cover Classes Ranges for Litter

\begin{tabular}{|c|c|c|c|c|c|c|}
\hline \multicolumn{2}{|c|}{ Cover Class } & \multirow{2}{*}{ Treatment } & \multirow{2}{*}{$\begin{array}{c}\text { Water Year } \\
1996\end{array}$} & \multirow{2}{*}{$\frac{\text { Median }}{5-25}$} & \multirow{2}{*}{$\frac{\text { Mode }}{5-25}$} & \multirow{2}{*}{$\frac{\text { Mean }}{-}$} \\
\hline \multirow{20}{*}{\multicolumn{2}{|c|}{ Litter }} & & & & & \\
\hline & & \multirow{9}{*}{ Burned } & 1997 & $50-75$ & $50-75$ & - \\
\hline & & & 1999 & $75-95$ & $95-100$ & $75-95$ \\
\hline & & & 2000 & $75-95$ & $75-95$ & $50-75$ \\
\hline & & & 2001 & $25-50$ & $25-50$ & $50-75$ \\
\hline & & & 2002 & $50-75$ & $25-50$ & $50-75$ \\
\hline & & & 2003 & $25-50$ & $25-50$ & $25-50$ \\
\hline & & & 2004 & $50-75$ & $50-75$ & $50-75$ \\
\hline & & & 2007 & $5-25$ & $5-25$ & $25-50$ \\
\hline & & & 2009 & $0-5$ & $5-25$ & $5-25$ \\
\hline & & \multirow{10}{*}{ Unburned } & 1996 & $5-25$ & $5-25$ & - \\
\hline & & & 1997 & $25-50$ & $25-50$ & - \\
\hline & & & 1999 & $50-75$ & $50-75$ & $50-75$ \\
\hline & & & 2000 & $25-50$ & $25-50$ & $25-50$ \\
\hline & & & 2001 & $25-50$ & $5-25$ & $25-50$ \\
\hline & & & 2002 & $25-50$ & $25-50$ & $25-50$ \\
\hline & & & 2003 & $5-25$ & $5-25$ & $5-25$ \\
\hline & & & 2004 & $25-50$ & $25-50$ & $25-50$ \\
\hline & & & 2007 & $5-25$ & $5-25$ & $25-50$ \\
\hline & & & 2009 & $25-50$ & $25-50$ & $25-50$ \\
\hline Class & 1 & 2 & 3 & 4 & 5 & 6 \\
\hline Percent Cover & 0 to 5 & 5 to 25 & 25 to 50 & 50 to 75 & 75 to 95 & 95 to 100 \\
\hline Midpoint & 2.5 & 15 & 37.5 & 62.5 & 85 & 97.5 \\
\hline
\end{tabular}


Table 3.9. Median, Mode, and Mean Percent Cover Classes Ranges for Bare Ground

\begin{tabular}{|c|c|c|c|c|c|c|}
\hline \multicolumn{2}{|c|}{ Cover Class } & Treatment & Water Year & Median & Mode & Mean \\
\hline \multirow{20}{*}{\multicolumn{2}{|c|}{ Bare Ground }} & \multirow{10}{*}{ Burned } & 1996 & $5-25$ & $5-25$ & - \\
\hline & & & 1997 & $5-25$ & $25-50$ & - \\
\hline & & & 1999 & $5-25$ & $0-5$ & $5-25$ \\
\hline & & & 2000 & $5-25$ & $5-25$ & $5-25$ \\
\hline & & & 2001 & $5-25$ & $5-25$ & $5-25$ \\
\hline & & & 2002 & $25-50$ & $25-50$ & $25-50$ \\
\hline & & & 2003 & $50-75$ & $50-75$ & $25-50$ \\
\hline & & & 2004 & $25-50$ & $50-75$ & $25-50$ \\
\hline & & & 2007 & $50-75$ & $50-75$ & $50-75$ \\
\hline & & & 2009 & $75-95$ & $75-95$ & $75-95$ \\
\hline & & \multirow{10}{*}{ Unburned } & 1996 & $5-25$ & $5-25$ & - \\
\hline & & & 1997 & $25-50$ & $25-50$ & - \\
\hline & & & 1999 & $5-25$ & $5-25$ & $25-50$ \\
\hline & & & 2000 & $25-50$ & $50-75$ & $25-50$ \\
\hline & & & 2001 & $25-50$ & $25-50$ & $25-50$ \\
\hline & & & 2002 & $25-50$ & $25-50$ & $25-50$ \\
\hline & & & 2003 & $50-75$ & $75-95$ & $50-75$ \\
\hline & & & 2004 & $50-75$ & $50-75$ & $50-75$ \\
\hline & & & 2007 & $50-75$ & $50-75$ & $50-75$ \\
\hline & & & 2009 & $50-75$ & $50-75$ & $50-75$ \\
\hline Class & 1 & 2 & 3 & 4 & 5 & 6 \\
\hline Percent Cover & 0 to 5 & 5 to 25 & 25 to 50 & 50 to 75 & 75 to 95 & 95 to 100 \\
\hline Midpoint & 2.5 & 15 & 37.5 & 62.5 & 85 & 97.5 \\
\hline
\end{tabular}


Table 3.10. Cover of Plant Species and Other Categories Observed in 2009 on the Burned and Unburned Sections of the Barrier and Two McGee Ranch Analog Sites

\begin{tabular}{|c|c|c|c|c|}
\hline Species & Barrier Burn & Barrier Unburned & McGee Old Burn & McGee Unburned \\
\hline Achillea millifolium & $0.02 \pm 0.02$ & 0 & 0 & 0 \\
\hline Achnatherum hymenoides & 0 & 0 & $1.19 \pm 0.72$ & $0.71 \pm 0.25$ \\
\hline Amsinckia lycopsoides & $0.09 \pm 0.04$ & $0.02 \pm 0.02$ & 0 & 0 \\
\hline Artemisia tridentata & $0.35 \pm 0.12$ & $30 \pm 1.12$ & $0.36 \pm 0.2$ & $21.9 \pm 2.53$ \\
\hline Bromus tectorum & $1.53 \pm 0.1$ & $1.06 \pm 0.1$ & $39.4 \pm 5.71$ & $4.88 \pm 1.1$ \\
\hline Centaurea diffusa & $0.05 \pm 0.03$ & 0 & 0 & 0 \\
\hline Chenopodium leptophyllum & $0.16 \pm 0.05$ & 0 & 0 & 0 \\
\hline Chrysothamnus viscidiflorus & $0.02 \pm 0.02$ & $0.1 \pm 0.1$ & 0 & 0 \\
\hline Crepis atribarba & 0 & 0 & 0 & $0.24 \pm 0.16$ \\
\hline Descurainia pinnata & $0.07 \pm 0.03$ & 0 & $0.24 \pm 0.16$ & $0.83 \pm 0.26$ \\
\hline Elymus elymoides & 0 & 0 & $0.36 \pm 0.2$ & $1.55 \pm 0.27$ \\
\hline Elymus wawawaiensis & $1.84 \pm 0.39$ & $0.3 \pm 0.07$ & 0 & 0 \\
\hline Ericameria nauseosa & $1.09 \pm 0.1$ & $0.19 \pm 0.11$ & $0.12 \pm 0.12$ & 0 \\
\hline Erigeron filifolius & 0 & 0 & 0 & $0.36 \pm 0.2$ \\
\hline Erodium cicutarium & $0.02 \pm 0.02$ & $0.02 \pm 0.02$ & 0 & 0 \\
\hline Grayia spinosa & 0 & 0 & 0 & $0.12 \pm 0.12$ \\
\hline Helianthus cusickii & 0 & 0 & $10.8 \pm 2.83$ & $4.64 \pm 1.32$ \\
\hline Machaeranthera canescens & $1.11 \pm 0.14$ & $0.05 \pm 0.03$ & $3.1 \pm 1.12$ & $0.6 \pm 0.24$ \\
\hline Melilotus officinalis & $1.56 \pm 0.37$ & 0 & 0 & 0 \\
\hline Poa ampla & 0.03 & 0.19 & 0 & 0 \\
\hline Poa bulbosa & 0 & $0.12 \pm 0.04$ & 0 & 0 \\
\hline Poa secunda & $0.07 \pm 0.03$ & $0.16 \pm 0.05$ & $18 \pm 2.66$ & $15.4 \pm 1.88$ \\
\hline Salsola kali & $19.5 \pm 0.86$ & 0 & $2.02 \pm 0.7$ & $0.12 \pm 0.12$ \\
\hline Sisymbrium altissimum & $2.1 \pm 0.23$ & $0.31 \pm 0.07$ & $2.86 \pm 1.14$ & 0 \\
\hline Sphaeralcea munroana & 0 & 0 & $0.12 \pm 0.12$ & $1.31 \pm 0.28$ \\
\hline Tragopogon dubius & $0.03 \pm 0.02$ & 0 & $0.6 \pm 0.24$ & 0 \\
\hline Vulpia microstachys & $0.03 \pm 0.02$ & $0.03 \pm 0.02$ & 0 & $0.6 \pm 0.24$ \\
\hline Grass & $3.51 \pm 0.42$ & $1.86 \pm 0.18$ & $58.9 \pm 4.88$ & $23.1 \pm 1.82$ \\
\hline Shrubs & $1.46 \pm 0.16$ & $30.3 \pm 1.13$ & $0.48 \pm 0.22$ & $22 \pm 2.57$ \\
\hline Forbs & $24.7 \pm 0.97$ & $0.4 \pm 0.1$ & $19.8 \pm 2.19$ & $8.1 \pm 1.4$ \\
\hline Soil cryptogams & 0 & $28.3 \pm 1.63$ & $6.79 \pm 1.98$ & $42.6 \pm 3.57$ \\
\hline Woody litter & $4.06 \pm 0.35$ & $3.28 \pm 0.25$ & $3.69 \pm 0.82$ & $10.8 \pm 1.32$ \\
\hline Herbaceous Litter & $3.89 \pm 0.33$ & $42.1 \pm 1.64$ & $49.4 \pm 4.8$ & $17.1 \pm 1.48$ \\
\hline Total litter & $7.95 \pm 0.52$ & $45.3 \pm 1.7$ & $53.1 \pm 4.72$ & $28 \pm 2.19$ \\
\hline Soil & $76.6 \pm 1.09$ & $25.5 \pm 1.22$ & $40.5 \pm 4.59$ & $19.3 \pm 1.98$ \\
\hline Rock & 15 & $12.1 \pm 0.44$ & $2.26 \pm 0.16$ & 2.5 \\
\hline Bare ground & $76.6 \pm 1.09$ & $53.8 \pm 2.06$ & $47.3 \pm 5.22$ & $61.9 \pm 3.47$ \\
\hline
\end{tabular}




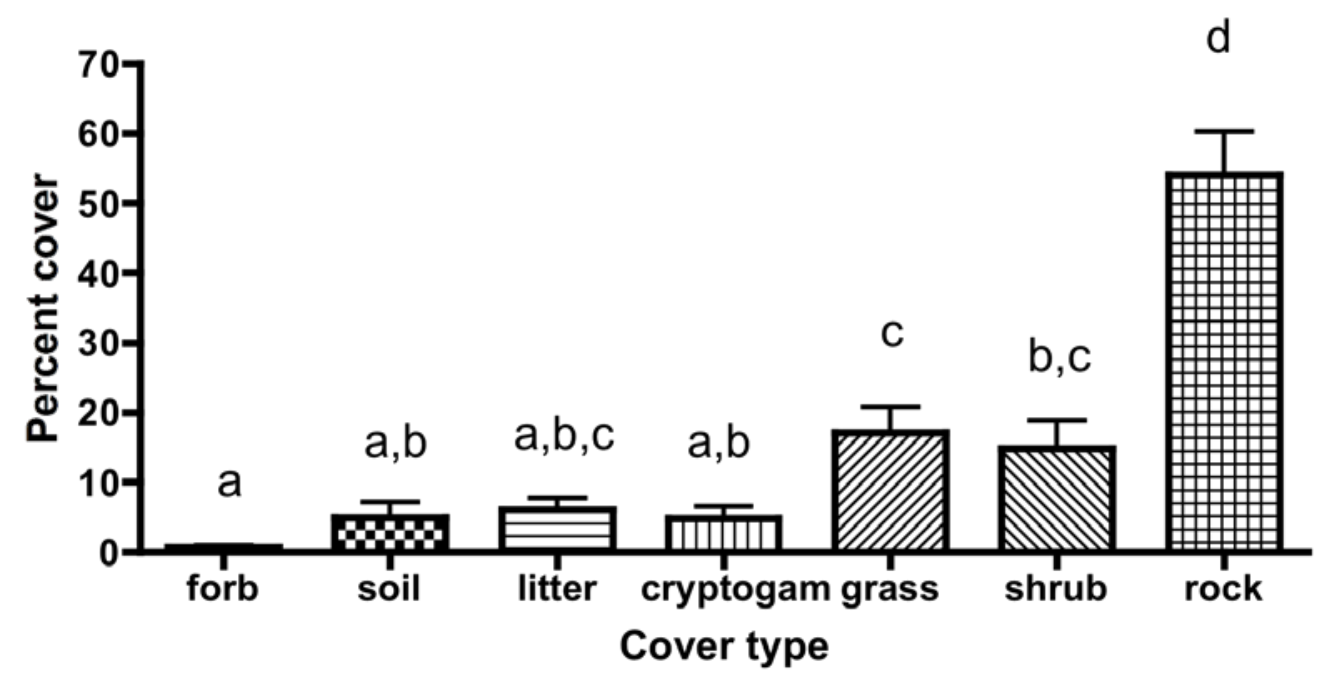

Figure 3.10. Mean Cover on the North and West Side Slopes of the Barrier. Error bars of one standard error of the mean $(n=24)$. Different letters indicate significant differences.

\subsubsection{Leaf Area Index}

Pre-burn LAI observations were made in the center of each quadrat in seven east/west rows. There were 12 quadrats in each row for a total of 83 observations. Quadrat 1 is on the west edge, and 13 is on the east edge of the surface with $n=7$ in each quadrat set. One quadrat value was lost. LAI values ranged from 0 in apparently very low to non-existent canopy conditions to 4.75 in the dense cover conditions along the first quadrat along the west edge of the surface. Quadrats along the two edges were combined $(n=28)$ and compared with quadrats in the center of the test area $(n=55)$. Mean LAI $(1.34 \pm 0.17)$ along the edges was significantly $(p<0.0001)$ greater than in the center $(0.47 \pm 0.043)$. The pattern of LAI across the surface (Figure 3.11) demonstrates the effect of location on canopy structure.

Post-burn measurements of LAI show that the mean LAI on the unburned half of the barrier $(1.13 \pm 0.087)$ was not significantly different from mean LAI in the McGee unburned plant community (0.692 \pm 0.129$)$. The mean LAI in the burned half of the barrier $(0.254 \pm 0.02)$ was not significantly different from the mean LAI in the McGee old burn plant community $(0.103 \pm 0.0 .031)$. Values in the two burned areas were significantly lower than those in the two unburned areas. 


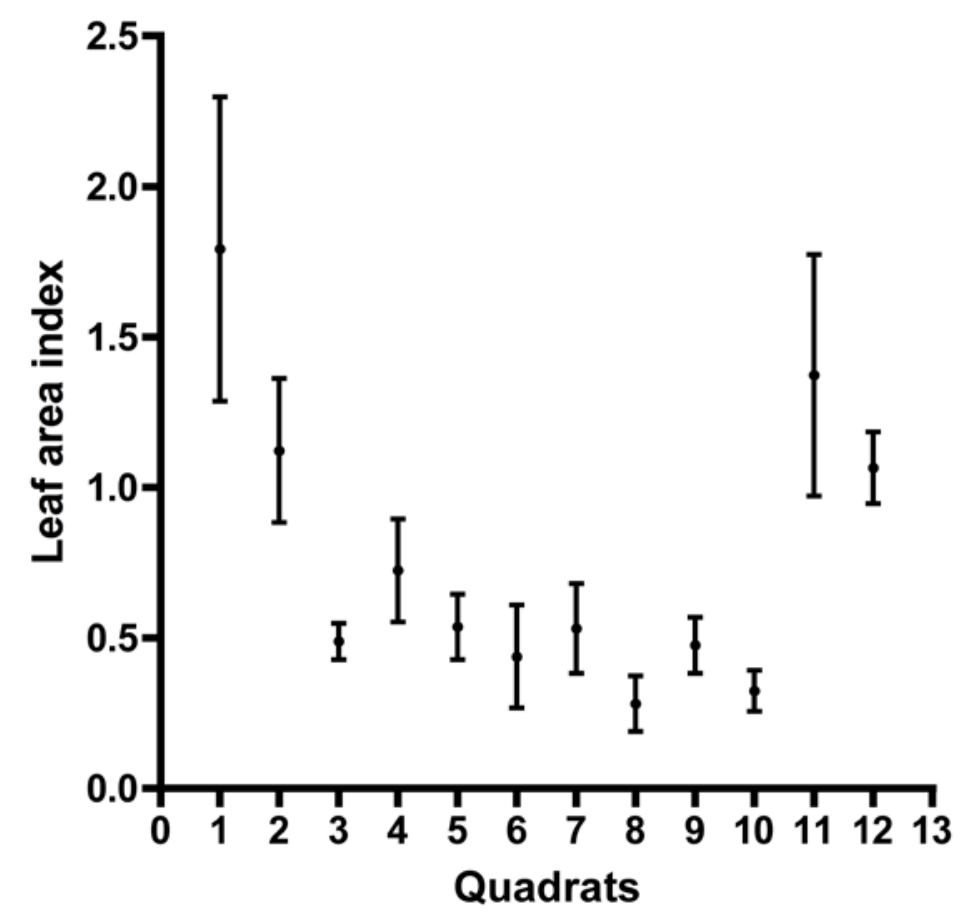

Figure 3.11. Pre-Burn LAI Across the Barrier Surface

\subsubsection{Plant Water Status}

The xylem pressure potential was measured on plants in the burned and unburned conditions. Measurements were made just before dawn to assess maximal xylem pressure potential. A. tridentata, $S$. kali, and M. officinalis were measured on the west, central, and east sides of the surface. In addition, on A. tridentata was measured in the unburned condition in late afternoon to determine the lowest possible values. There was no significant $(p=0.570)$ effect of species on xylem pressure potential for early morning readings in the burned condition. These values were then combined to test the effect of location on xylem pressure potential in the burned condition. Location had a significant $(p=0.0045)$ effect on xylem pressure potential. Plants on the west third of the surface had significantly greater xylem pressure $(-17.5 \pm 0.89$ bars, $n=12)$ than those on the middle and east thirds of the surface $(-26.3 \pm 2.49$ bars, $\mathrm{n}=13$ ). This observation suggests that similar variation in the soil water potential may exist on the burned half of the barrier.

Early morning and late afternoon observations were compared on A. tridentata in the unburned condition. There was no significant $(\mathrm{p}=0.523)$ effect of observation time on xylem pressure potential. The mean value for all combined observations was $-74.3 \pm 3.19$ bars $(n=11)$. Having early morning pressure potential values as low as those in late afternoon means that $A$. tridentata has essentially extracted all water available to it from the soil profile at this time of year. The species is nearly inactive under these conditions. Values ranged from -51 to -87.5 bars. 


\subsubsection{Biological Activity and Soil Carbon Dioxide Flux}

Soil respiration rates in the burned and unburned conditions were compared when surface soils were dry and when surface soils had been wetted by rain to an average depth of $33.8 \pm 1.1 \mathrm{~mm}$ (Table 3.11). When the upper soil profile was dry, soil respiration rates were significantly $(p=0.0205)$ greater in the burned treatment than in the unburned treatment. When the upper soil profile had been wetted, there was no significant $(\mathrm{p}=0.3394)$ difference between the treatments. Given that observations were taken from the same location in wet and dry conditions, dry rates were subtracted from wet rates and compared between the treatments. These differences were not significantly $(p=0.1936)$ different; thus observations in the treatments were combined to compare wet and dry rates. Soil respiration rates $\left(\mu \mathrm{mol} \mathrm{CO} \mathrm{Cm}^{-2} \mathrm{~s}^{-1}\right)$ were significantly $(\mathrm{p}<0.0001, \mathrm{n}=12)$ greater in the wet surface soils $(0.834 \pm 0.0725)$ than in the dry surface soils $(0.104 \pm 0.0137)$.

Table 3.11. Mean Soil Respiration Rates \pm 1 Standard Error of the Mean $\left(\mu \mathrm{mol} \mathrm{CO}_{2} \mathrm{~m}^{-2} \mathrm{~s}^{-1}\right)$

\begin{tabular}{ccc}
\hline & \multicolumn{2}{c}{ Treatment } \\
Condition & Unburned & Burned \\
\hline Dry & $0.074 \pm 0.013 \boldsymbol{a}$ & $0.134 \pm 0.018 \boldsymbol{b}$ \\
Wet & $0.907 \pm 0.124 \boldsymbol{c}$ & $0.76 \pm 0.074 \boldsymbol{c}$ \\
\hline $\begin{array}{l}\text { Differing letters within conditions indicate significant differences between } \\
\text { treatments }(\mathrm{n}=6) .\end{array}$ \\
\hline
\end{tabular}

The higher respiration under dry conditions in the burned area compared with the unburned area is likely a result of the wetter soil profile. The wetter soil profile, as evidenced by plants with higher water potential values, yields more active plants that have higher root-respiration rates. It is likely that soil respiration is primarily root respiration given that the soil surface was very dry, limiting surface microbial activity. When the surface soils were wetted, it is likely that a significant component of the respiration was microbial. Given that soil organic matter increased or decreased depending on the assessment method after the fire, it is possible that there was enough organic carbon in the burned soil to support respiration rates as high as in the unburned soil. While we did not attempt to account for the root activity or biomass in the wetted soil zone, it is likely that these roots were more active when wetted by the rain. Roots were observed in the upper few centimeters of the soil in the burned area, suggesting that they had not yet decomposed after the fire or that they are, in part, new roots from active vegetation.

\subsubsection{Seed Bank Assessment}

There was no difference in the number of species emerging from the seed bank before and after the fire (Table 3.12). There were fewer species emerging from the seed bank on the side slopes and more species emerging from the two McGee Ranch analog sites (Table 3.12). The most interesting observation is the emergence of $A$. tridentata from the seed bank after the fire, which suggests that this dominant shrub will return after a fire. This observation is in contrast to the general belief that $A$. tridentata does not recover after a fire. There was no re-sprouting after the fire. When emerged seedlings of all species were combined in each experimental unit for the high $(n=17)$ and low $(n=19)$ fuel load areas on the barrier surface, there was no significant $(\mathrm{p}=0.86)$ effect of fire intensity on seedling density. There were $48.2 \pm 12.7$ seedlings per $\mathrm{m}^{-2}$ in the high fuel load area and $57.9 \pm 24.3$ seedlings per $\mathrm{m}^{-2}$ in the low fuel load area. When high and low fuel samples were combined, there was no significant $(p=0.76)$ effect of 
Table 3.12. Species Emerging from the Seed Bank on the Burned and Unburned Sections of the Barrier, the Side-slope, and at the two McGee Ranch Analog Sites

\begin{tabular}{|c|c|c|c|c|c|}
\hline Species & Barrier After Burn & $\begin{array}{c}\text { Barrier Before } \\
\text { Burn } \\
\end{array}$ & Side Slopes & $\begin{array}{l}\text { McGee Old } \\
\text { Burn }\end{array}$ & $\begin{array}{c}\text { McGee } \\
\text { Unburned }\end{array}$ \\
\hline Achnatherum hymenoides? & & & & $\mathrm{X}$ & $\mathrm{X}$ \\
\hline Artemisia tridentate & $\mathrm{X}$ & $\mathrm{X}$ & & $\mathrm{X}$ & $X$ \\
\hline Bromus tectorum & $\mathrm{X}$ & $X$ & $\mathrm{X}$ & $\mathrm{X}$ & $X$ \\
\hline Descurainia pinnata & & $X$ & & $\mathrm{X}$ & $X$ \\
\hline Elymus elymoides & & & & $\mathrm{X}$ & $X$ \\
\hline Elymus wawawaiensis & $\mathrm{X}$ & $X$ & & & \\
\hline Erodium cicutarium & $\mathrm{X}$ & & $\mathrm{X}$ & & \\
\hline Holosteum umbellatum & $X$ & $X$ & & $\mathrm{X}$ & $X$ \\
\hline Lactuca serriola & & $X$ & & & \\
\hline Machaeranthera canescens & & & & $\mathrm{X}$ & \\
\hline Poa bulbosa & $X$ & $X$ & & & \\
\hline Poa secunda & & & & $\mathrm{X}$ & $X$ \\
\hline Salsola kali & & & & $\mathrm{X}$ & $X$ \\
\hline Sisymbrium altissimum & $\mathrm{X}$ & & $X$ & $\mathrm{X}$ & $X$ \\
\hline Sphaeralcea munroana & & & & $\mathrm{X}$ & $\mathrm{X}$ \\
\hline Verbena bracteata & $\mathrm{X}$ & $X$ & & & \\
\hline Total Number of Species & 8 & 8 & 3 & 11 & 10 \\
\hline
\end{tabular}

the fire on seedling density. There were $51.7 \pm 10.8$ seedlings per $\mathrm{m}^{-2}(\mathrm{n}=36)$ before the fire and $50.6 \pm 13.9$ seedlings per $\mathrm{m}^{-2}(\mathrm{n}=36)$ after the fire.

The seedling density of $A$. tridentata was significantly greater at the McGee Ranch old burn site than at the barrier surface (Table 3.13). Seedling density was highly variable, though with no difference detected between the two McGee Ranch sites. Furthermore, there were no significant differences among the barrier plots before and after the fire and the unburned McGee Ranch site. Bromus tectorum seedling density was very high on the side slopes, not significantly different at the two McGee Ranch sites, and much lower on the barrier surface. The native annual, $D$. pinnata, was very common at the two McGee Ranch sites and much greater than on the barrier. Seedlings of E. wawawaiensis were found before and after the fire from the seed bank on the barrier surface, but were highly variable. There were very few seedlings found on the barrier surface. Poa secunda seedlings from the seed bank were not found on the barrier, but were very common from the samples at the McGee Ranch unburned site. There were very few $P$. secunda plants on the barrier surface, limiting the likelihood of finding them in the seed bank. Both S. kali and S. altissimum were significantly greater on the old burn McGee Ranch site than at the unburned McGee Ranch site while there were no seedlings observed from any of the barrier samples. Both species were found growing on the barrier surface after the fire, suggesting that viable seed is either in the seed bank, and they did not germinate from the samples in the greenhouse, or the seed arrived on the surface after the fire from surrounding seed sources. Both species are recognized as responding 
Table 3.13. Mean Seedling Density ( \pm 1 standard error of the mean) from the Seed Bank at Five Study Sites

\begin{tabular}{|c|c|c|c|c|c|}
\hline \multirow[b]{2}{*}{ Species } & \multicolumn{5}{|c|}{ Site } \\
\hline & $\begin{array}{c}\text { Barrier Before } \\
\text { Fire } \\
(\mathrm{n}=36)\end{array}$ & $\begin{array}{l}\text { Barrier After Fire } \\
\quad(\mathrm{n}=36)\end{array}$ & $\begin{array}{l}\text { Side Slope } \\
(\mathrm{n}=18)\end{array}$ & $\begin{array}{l}\text { McGee Ranch } \\
\text { Old Burn } \\
(\mathrm{n}=36)\end{array}$ & $\begin{array}{l}\text { McGee Ranch } \\
\text { Unburned } \\
(\mathrm{n}=36)\end{array}$ \\
\hline Artemisia tridentata & $1.67 \pm 0.934 b$ & $5.56 \pm 3.25 \boldsymbol{b}$ & 0 & $175 \pm 83.8 \boldsymbol{a}$ & $21.1 \pm 7.69 a, b$ \\
\hline Bromus tectorum & $1.22 \pm 0.453 c, d$ & $0.0556 \pm 0.0387 d$ & $352 \pm 85.7 a$ & $139 \pm 38.5 \boldsymbol{b}$ & $56.7 \pm 17.4 \boldsymbol{b}, \boldsymbol{c}$ \\
\hline Descurainia pinnata & $2.22 \pm 1.33 \boldsymbol{a}$ & $0 a$ & $0 a$ & $59.4 \pm 19.9 \boldsymbol{b}$ & $201 \pm 35.1 c$ \\
\hline Elymus wawawaiensis & $4.44 \pm 3.91 a$ & $13.9 \pm 13.3 a$ & 0 & & \\
\hline Poa secunda & 0 & 0 & 0 & $8.89 \pm 3.86 a$ & $473 \pm 111 \boldsymbol{b}$ \\
\hline Salsola kali & 0 & 0 & 0 & $80 \pm 35 a$ & $12.8 \pm 5.53 \boldsymbol{b}$ \\
\hline Sisymbrium altissimum & 0 & 0 & 0 & $41.7 \pm 9.41 a$ & $12.2 \pm 3.50 b$ \\
\hline Verbena bracteata & $3.89 \pm 1.34 a$ & $10 \pm 3.69 a$ & 0 & 0 & 0 \\
\hline
\end{tabular}

favorably to fire. Verbena bracteata seedlings were found in the seed bank of samples before and after the fire. None were found on the side slope or at the two McGee Ranch sites.

Seedling density was very high under A. tridentata canopies in the old burn area (Table 3.14). There were few A. tridentata plants in the area, but they likely produced large amounts of seed given that there is little competition for water. Competition by the dominant $B$. tectorum likely restricts rapid establishment of $A$. tridentata. At the unburned site, $A$. tridentata is much more common across sample sites, but seedling numbers are low. It is likely that low amounts of seed are produced for each individual plant, given that they are common at the site and likely compete with each other for water. Bromus tectorum was very common under $S$. kali canopies at the old burn site and was significantly denser than in other conditions other than under A. tridentata. There was little effect of conditions on $B$. tectorum seedling density at the unburned site. There was little effect of conditions at either analog site for $D$. pinnata. The seed bank for $P$. secunda was similar across conditions at both analog sites. The only significant effect was much greater density under bunchgrass canopies than in the bare swales at the unburned site. Salsola kali seedling density was significantly greater under its canopy than in any of the other conditions at both sites. Sisymbrium altissimum was evenly distributed among the conditions at both sites.

\subsubsection{Small Mammal Habitat and Barrier Use}

Of burrowing wildlife, no other group of organisms influences near-surface soil mixing more profoundly than mammals. A pre-burn survey was conducted across the entire surface to document evidence of use and intrusion (burrowing) by insects and small mammals. Evidence of animal use was observed on the surface and included direct observation (traps) as well as the presence of droppings, tracks, nests, burrows, holes, and resting spots. The most common mammal found on the surface by trapping was deer mice (Peromyscus sp.).

Another survey was conducted immediately after the burn. Two species were captured during a total of 50 trap nights. The predominant species in both areas was the deer mouse (Peromyscus maniculatus). One great basin pocket mouse (Perognathus parvus) was trapped in the unburned region. The relative abundance of small mammals was higher in the burned area trapping grid; estimated at 21 new captures per 100 trap nights, as opposed to 4 new captures per 100 trap nights measured in the unburned trapping grid. Adults and juveniles were captured, indicating that the small mammals were residents to the area, as 
Table 3.14. Mean Seedling Density ( \pm 1 standard error of the mean) from the Seed Bank Under Six Conditions at the two McGee Ranch Analog Sites (Treatment, b = old burn, $\mathrm{u}=$ unburned)

\begin{tabular}{|c|c|c|c|c|c|c|c|}
\hline Species & Trt & Under S. Kali & $\begin{array}{l}\text { Under A. } \\
\text { Tridentata }\end{array}$ & Bunchgrass & Hummock & $\begin{array}{l}\text { Cryptogamic } \\
\text { Swale }\end{array}$ & Bare Swale \\
\hline \multirow{2}{*}{ A. tridentata } & $\mathrm{b}$ & $0 a$ & $1040 \pm 339 b$ & $0 a$ & $0 a$ & $0 a$ & $10 \pm 6.83 a$ \\
\hline & $\mathrm{u}$ & $10 \pm 6.83 a$ & $56.7 \pm 38.8 a$ & $0 \boldsymbol{a}$ & $6.67 \pm 4.22 a$ & $6.67 \pm 6.67 a$ & $46.7 \pm 16.9 a$ \\
\hline \multirow{2}{*}{ B. tectorum } & $\mathrm{b}$ & $463 \pm 138 a$ & $193 \pm 104 \boldsymbol{a}, \boldsymbol{b}$ & $93.3 \pm 25.6 \boldsymbol{b}$ & $63.3 \pm 40.5 b$ & $13.3 \pm 8.43 \boldsymbol{b}$ & $6.67 \pm 4.22 b$ \\
\hline & $\underline{\mathrm{u}}$ & $40 \pm 25.8 \boldsymbol{a}, \boldsymbol{b}$ & $76.7 \pm 61.4 \boldsymbol{a}, \boldsymbol{b}$ & $147 \pm 68.1 a$ & $50 \pm 30.4 \boldsymbol{a}, \boldsymbol{b}$ & $26.7 \pm 12.3 \boldsymbol{a}, \boldsymbol{b}$ & $0 b$ \\
\hline \multirow{2}{*}{ D. pinnata } & $\mathrm{b}$ & $50 \pm 26.2 a, b$ & $3.33 \pm 3.33 \boldsymbol{b}$ & $20 \pm 12.6 a, b$ & $217 \pm 96.8 a$ & $26.7 \pm 12.3 \boldsymbol{a}, \boldsymbol{b}$ & $40 \pm 11.5 a, b$ \\
\hline & $\underline{\mathrm{u}}$ & $117 \pm 28 a$ & $113 \pm 38.5 a$ & $360 \pm 138 a$ & $270 \pm 74.1 a$ & $227 \pm 76.9 a$ & $120 \pm 93.2 a$ \\
\hline \multirow{2}{*}{ P. secunda } & b & $26.7 \pm 19.8 a$ & $10 \pm 4.47 a$ & $10 \pm 10 a$ & $3.33 \pm 3.33 \mathbf{a}$ & $3.33 \pm 3.33 a$ & $0 \pm 0 a$ \\
\hline & u & $357 \pm 104 a, b$ & $420 \pm 151 a, b$ & $967 \pm 383 a$ & $773 \pm 455 \boldsymbol{a}, \boldsymbol{b}$ & $287 \pm 127 \boldsymbol{a}, \boldsymbol{b}$ & $36.7 \pm 15.8 \boldsymbol{b}$ \\
\hline \multirow{2}{*}{ S. kali } & $\mathrm{b}$ & $387 \pm 164 a$ & $13.3 \pm 13.3 \boldsymbol{b}$ & $26.7 \pm 16.1 b$ & $33.3 \pm 29.5 \boldsymbol{b}$ & $16.7 \pm 16.7 \boldsymbol{b}$ & $3.33 \pm 3.33 \boldsymbol{b}$ \\
\hline & u & $66.7 \pm 22.9 a$ & $0 b$ & $3.33 \pm 3.33 \boldsymbol{b}$ & $6.67 \pm 6.67 \boldsymbol{b}$ & $0 b$ & $0 b$ \\
\hline \multirow{2}{*}{ S. altissimum } & $\mathrm{b}$ & $100 \pm 44.1 a$ & $20 \pm 10.3 \boldsymbol{a}, \boldsymbol{b}$ & $13.3 \pm 6.67 b$ & $40 \pm 11.5 a, b$ & $46.7 \pm 18.4 \vec{a}, \boldsymbol{b}$ & $30 \pm 13.4 \boldsymbol{a}, \boldsymbol{b}$ \\
\hline & $\mathrm{u}$ & $36.7 \pm 14.1 a$ & $6.67 \pm 4.22 a$ & $3.33 \pm 3.33 \boldsymbol{a}$ & $6.67 \pm 4.22 a$ & $6.67 \pm 4.22 a$ & $13.3 \pm 9.89 \boldsymbol{a}$ \\
\hline
\end{tabular}

opposed to dispersed migrants from other areas. No reproductively active specimens were encountered. In addition, a number of side-blotched lizards (Uta stansburiana) were observed during the trapping event.

Indirect indices of animal activity, such as evidence of use by rabbits, coyotes, lizards, and invertebrates (in addition to small mammals), were common in both areas. A number of small, relatively shallow (less than $10 \mathrm{~cm}$ deep) excavations were noted throughout both trapping areas. The bulk of these excavations were believed to be made by resident lizards, but there was some evidence that some of these excavations were also made by darkling beetles and small mammals. Additionally, two areas in the unburned trapping grid contained evidence of underground small mammal burrow systems likely constructed by resident pocket mice. Based on several species of pocket mice, Kennedy et al. (1985) found that $50 \%$ of the burrow system is distributed within the top $0.5 \mathrm{~m}$ below ground surface and $90 \%$ is distributed within the top meter. Pocket mice typically construct burrows less than $2.5 \mathrm{~cm}$ in diameter, and other small mammal burrows common to the site are typically wider; for example, deer mouse burrows are up to $10 \mathrm{~cm}$ in diameter (Laundré 1989).

The barrier surface was again examined for evidence of use and intrusion (burrowing) by insects and small mammals on September 13, 2009, almost 1 year after the fire. Animal holes were significantly $(\mathrm{p}<0.0001)$ more prevalent on the unburned half $\left(0.0414 \pm 0.00737\right.$ holes $\left.\mathrm{m}^{-2}\right)$ than on the burned half $\left(0.0054 \pm 0.002\right.$ holes $\left.\mathrm{m}^{-2}\right)$. Of 61 holes found in all the plots, 31 were large and 30 were small. Of 21 holes dug by rodents, 20 were large. Of 38 holes dug by insects, 9 (23.7\%) were large. There were no significant $(\mathrm{p}>0.05)$ linear relationships between location $(\mathrm{X}, \mathrm{Y})$ and hole density. Cottontail rabbit (Sylvilagus nuttallii) use, indicated by the percentage of plots with feces in each of 25 rows, was positively correlated with percent cover of $E$. wawawaiensis (percentage of plots with feces $=27.7+5.9 *$ mean \% elwa cover; $\mathrm{p}=0.0077$ ). Most E. wawawaiensis plants had experienced herbivory, which is most liked by rabbits. Coyote feces were noted in two locations on the surface.

Galls, most likely attributed to flies or wasps, were found infesting a number of $A$. tridentata plants. Some of the A. tridentata were heavily infested, resulting in damage to the shrub. Of 144 plots in the unburned half of the barrier, 102 (71\%) had infested shrubs, and 19\% of the plots had heavily infested 
shrubs. This infestation will likely reduce the population density of A. tridentata in future years. Only one plot in the burned half of the surface had galls on an A. tridentata seedling.

\subsection{Simulated Fire}

Weather conditions on the day of the burn were sunny with a mean temperature of $24^{\circ} \mathrm{C}\left(75^{\circ} \mathrm{F}\right)$ and a slight wind from the south to the north. A liquid foam line was applied before the fire was initiated to separate the area to be burned (north half) from the south half. Figure 3.13 shows the ground fire crew for HFD preparing to ignite the test plots.

The fire was ignited at 3:15 PM by three ground fire crew members (Figure 3.14). The fire on top of the barrier was fast moving with flames reaching as high as $9 \mathrm{~m}(30 \mathrm{ft})$. Flame heights exceeded the 6-m (20-ft) flame-height rods but were estimated using video records with nearby infrastructure being used as a scale. Not all of the vegetation near the edges of the barrier was initially consumed. The fire groundcrew revisited unburned areas and ignited unburnt or partially burnt plants with drip torches. The lower burn efficiency around the edges of the barrier may be related to the size and moisture content of the biomass. Plants around the edges of the barrier were typically bigger, perhaps because of a larger amount of available moisture that accumulates at the capillary break near the edge. Figure 3.15 through

Figure 3.17 show different stages of the fire.

\subsubsection{Fire Intensity}

The degree of fire intensity was given a relative score with a value of 1 assigned to scorching whereas a value of 5 was assigned to the darkest carbonized areas of the fire pole. Values were averaged on each pole, and the average was used to create a fire intensity map. Figure 3.18 shows the relative fire or scorch intensity for the burnt area. The relative fire or scorch intensity was the greatest on the north to northwest and west sides while the lowest values were found along the northeast corner and southeast corners. This pattern is similar to the fuel load and air temperature patterns. After the burn, the surface was examined to identify any mosaic patterns that might be indicative of variable fire severity.

Fire intensity was verified by soil and air temperature measurements. The time-course of temperature before, during, and after the fire was recorded with HOBO data loggers, and examples of these data are shown in Figure 3.19. These two temperature time-courses were taken from one tower at the hottest part of the barrier surface. Temperatures ranged from $250^{\circ} \mathrm{C}\left(482^{\circ} \mathrm{F}\right)$ at $1.5 \mathrm{~cm}(0.6 \mathrm{in}$.) below the surface to over $700^{\circ} \mathrm{C}\left(1292^{\circ} \mathrm{F}\right)$ at $1 \mathrm{~m}(3.3 \mathrm{ft})$ above the surface. Results show that the air temperature rose much higher than the soil temperature. This can be expected because of the large amount of fuel on the surface and the flame heights. In addition, the thermal conductivity of soil is strongly dependent on moisture with dry soils being very poor thermal conductors. With little soil organic matter, the only other possible source of fuel in the subsurface would have been live roots, and as a result, there would have been little transmission of heat in the subsurface.

After the peak temperature was attained, the air temperature also fell off much more rapidly than the soil temperature. The effect of the fire on soil temperature persisted for about 2 hours (Figure 3.19). 


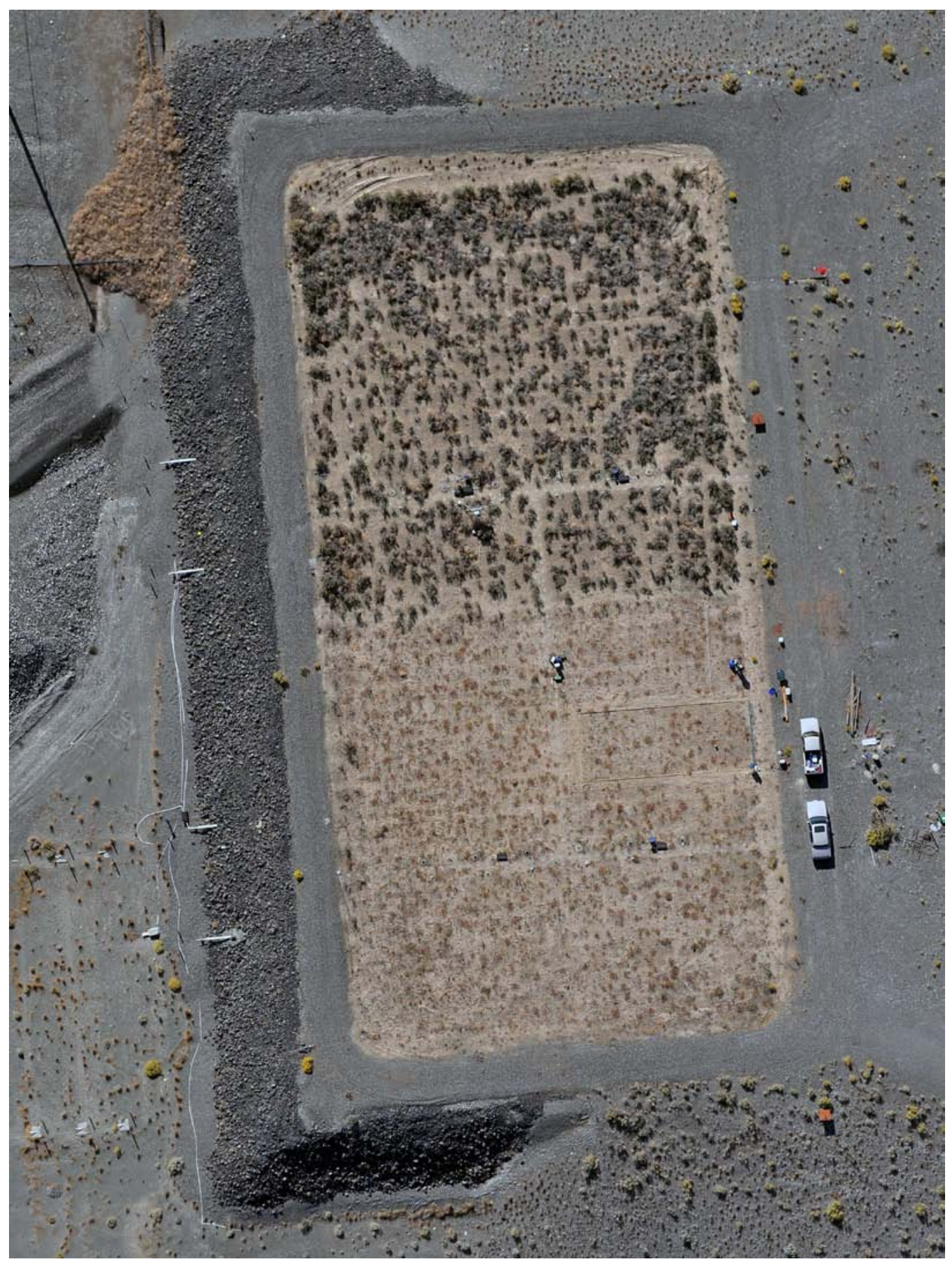

Figure 3.12. South Facing Aerial View of the Barrier on September 30, 2009 Showing the Burnt North Section and Unburned South Section One Year. 


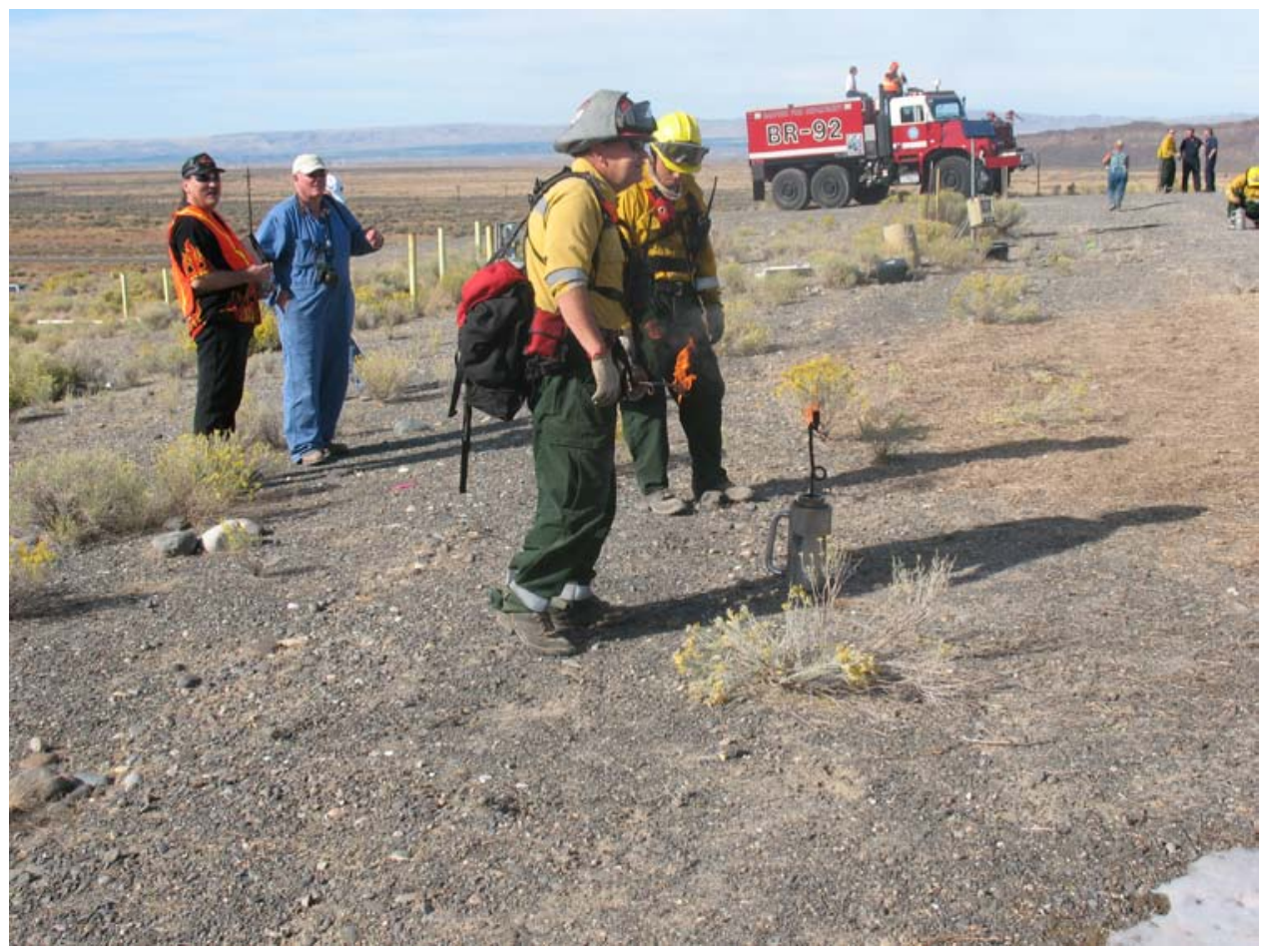

Figure 3.13. Ground Fire Crew from the Hanford Fire Department Preparing to Ignite Test Plots 


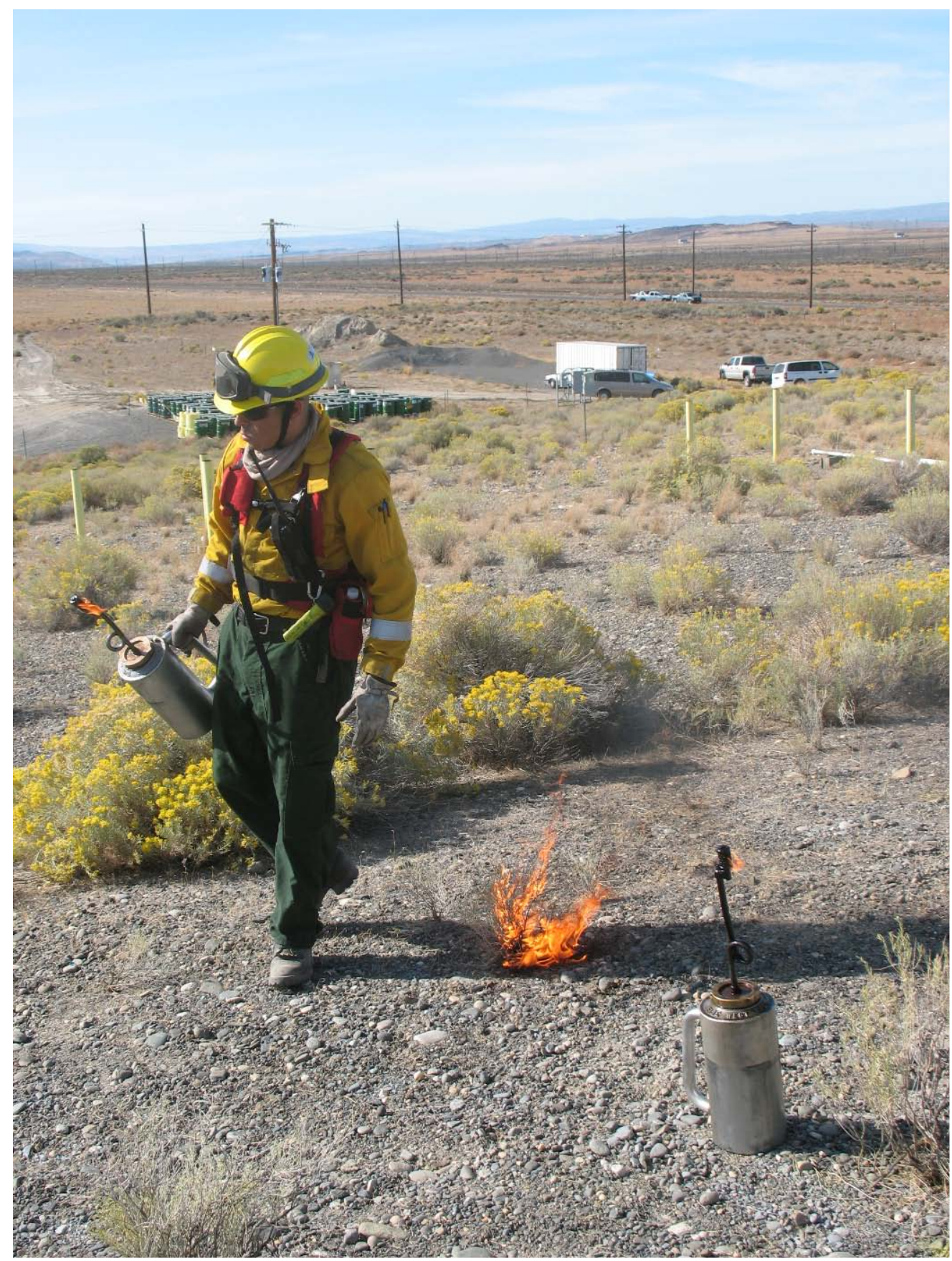

Figure 3.14. Ignition of the Test Plots by the Crew from the Hanford Fire Department. The Fire was Ignited at 3:15 PM September 26, 2008. 


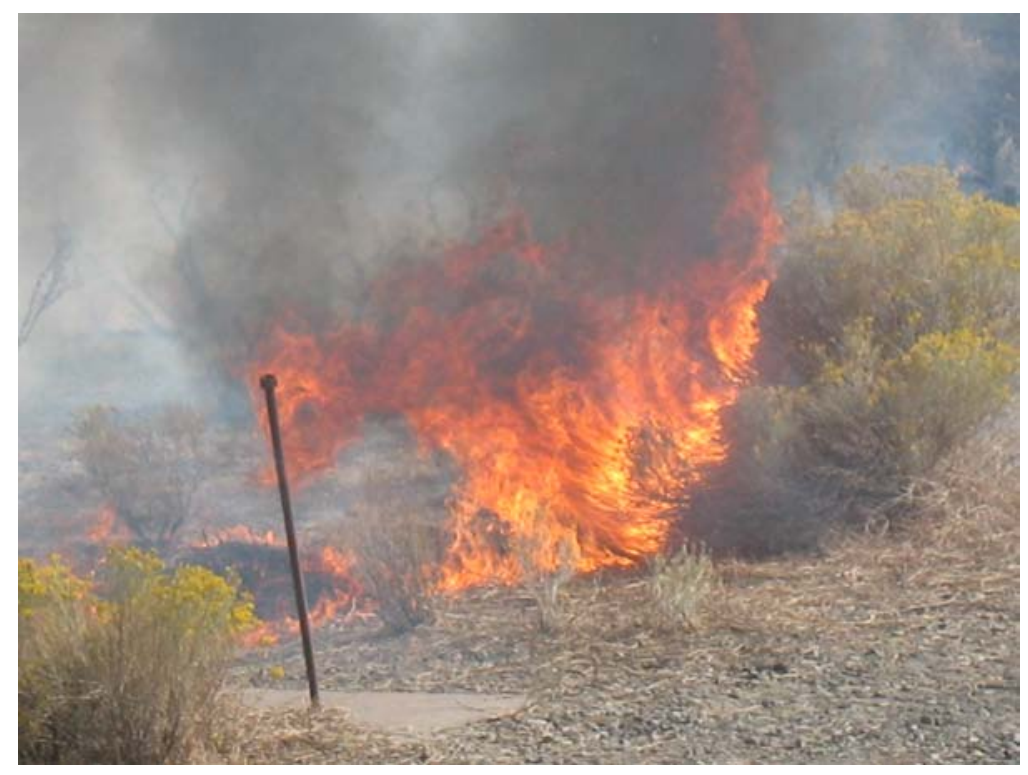

Figure 3.15. Rabbit Brush Near Edge of Barrier Engulfed in Flames Shortly After Ignition

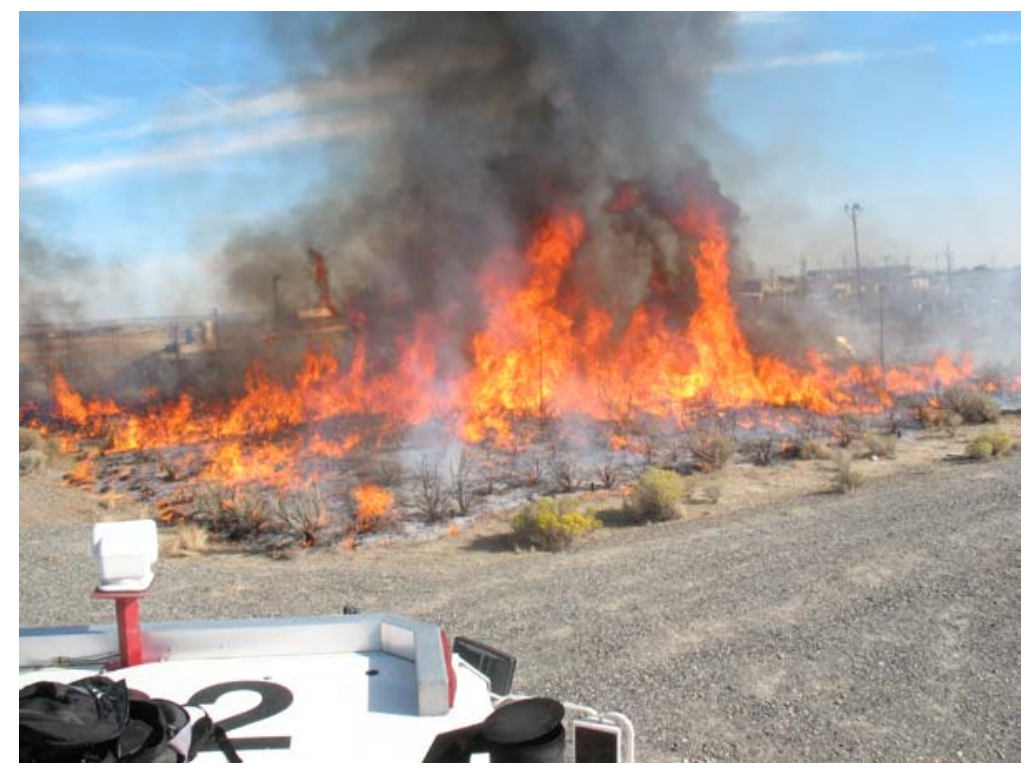

Figure 3.16. A View of the Fire from Southwestern Edge of the Plot About 4 Minutes after Ignition. The Photograph was taken from atop of the HFD Bush Rig. 


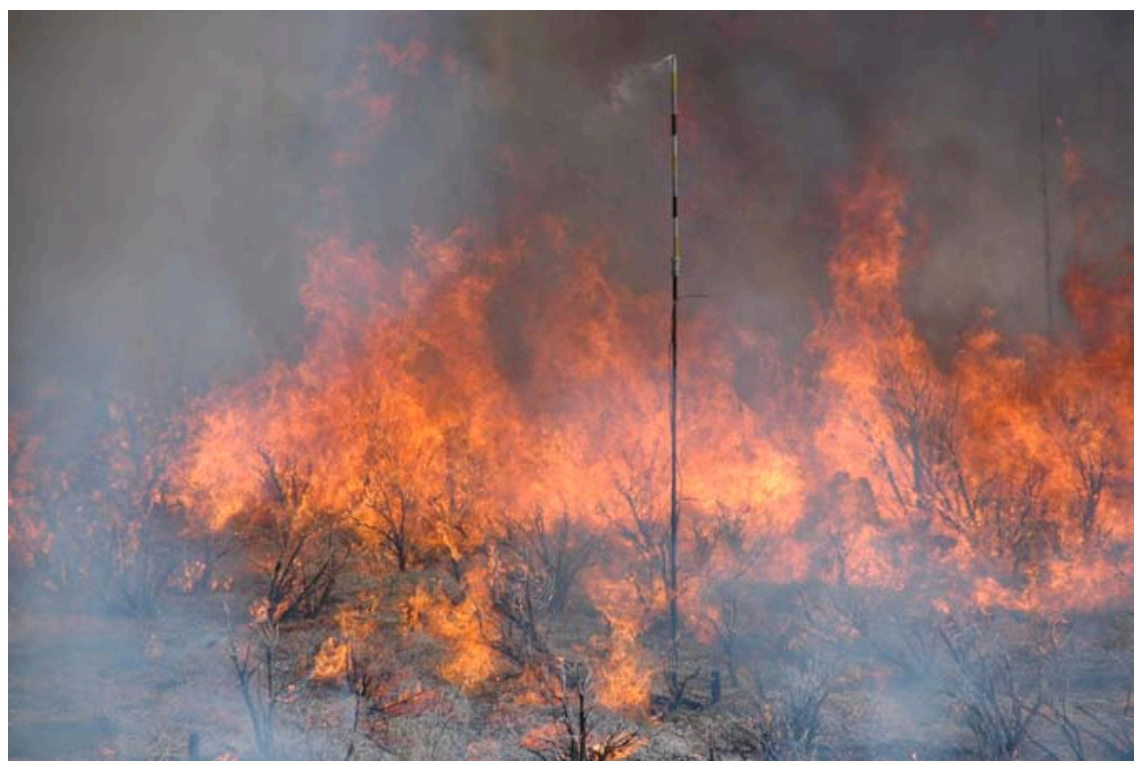

Figure 3.17. Painted Fire Pole in Foreground Showing a Thermocouple Mounted Perpendicular to the Pole at a Height of $2 \mathrm{~m}$

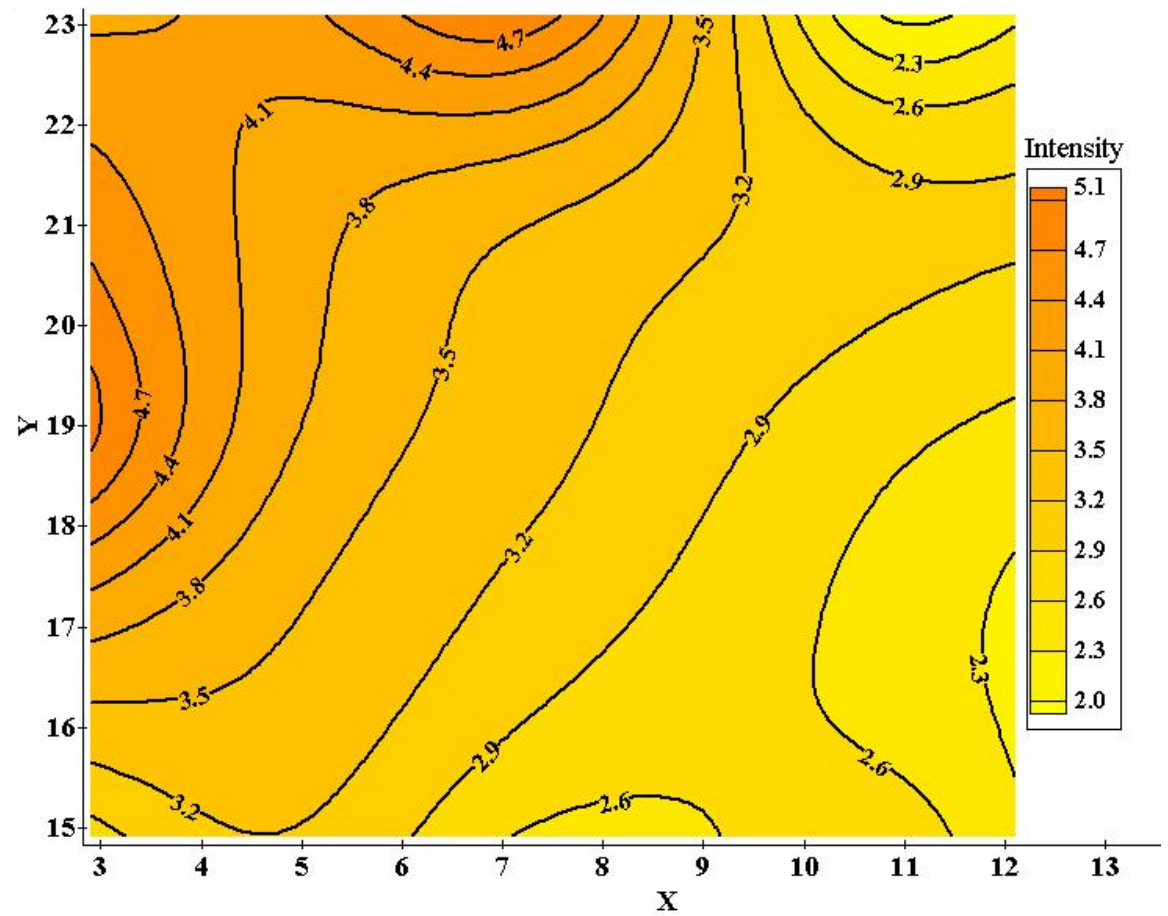

Figure 3.18. Fire or Scorch Intensity Mapped Across the Burned Area. The $\mathrm{X}$ and $\mathrm{Y}$ edges denote positions on the surface. The distance between coordinate values is 3 meters. 


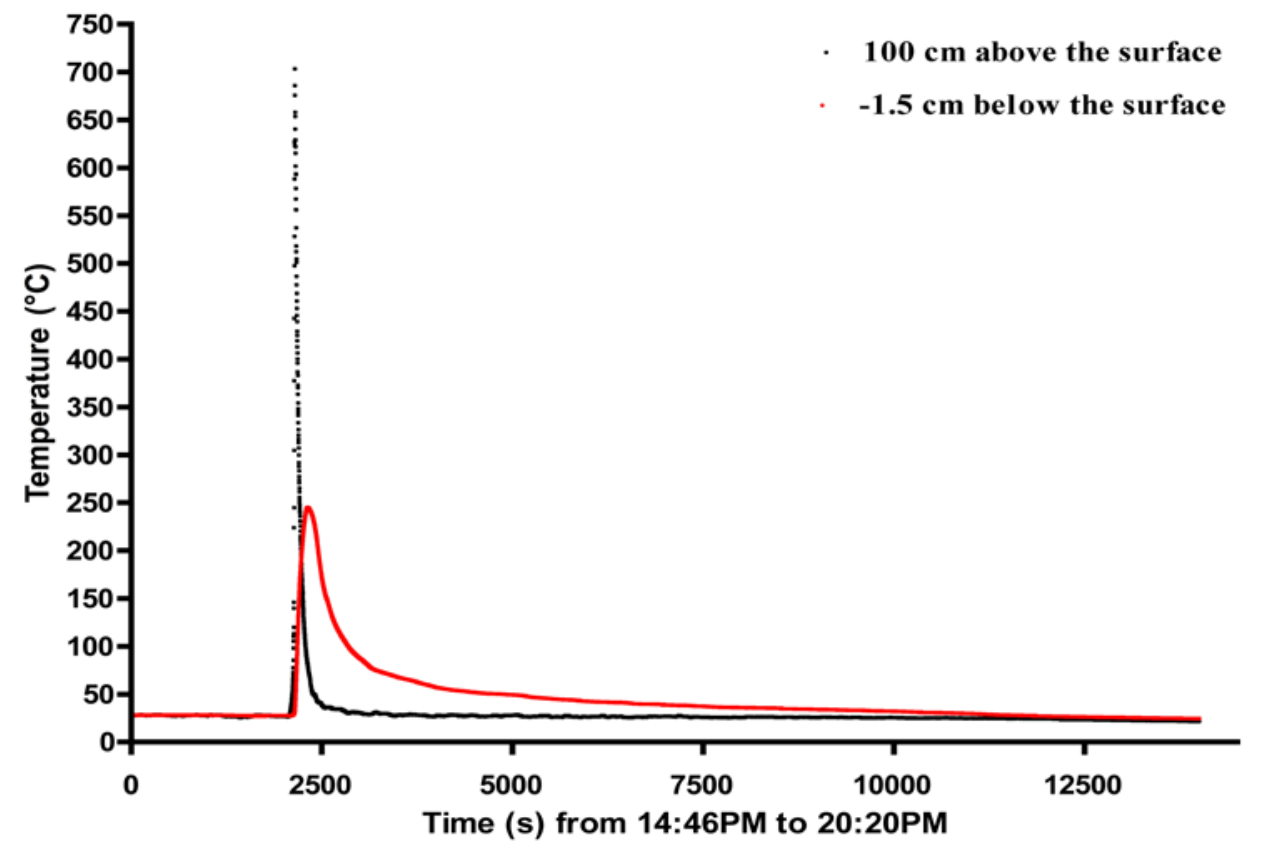

Figure 3.19. Temperature in the Air and Soil Before, During, and After the Fire

These differences can again be attributed to differences in thermal conductivity between the soil and air and differences in the effects of wind circulation on the redistribution of heat. The mean maximum temperatures were the lowest below the surface rising to a maximum at $10 \mathrm{~cm}$ above the surface. Temperatures then decreased with increasing height (Figure 3.20). The total duration of elevated temperature above that just before the fire was lower as the thermocouple became higher above the ground surface (Figure 3.20). Below ground, there is an apparent reduction of integrated temperature compared with that at the ground surface, but the effect is not statistically significant. The temperature was integrated over a 2.61-hr period until temperatures fell to those observed before the fire. Soil and air temperatures measured at the fire poles were used to generate contour plots of the spatial distribution of temperature above and below the surface. Figure 3.21 shows a plot of peak temperatures recorded across the burnt area. Both air temperature (Figure 3.22a) and soil temperature (Figure 3.22b) maps show that the highest temperatures were recorded in the plots with the higher fuel load, e.g., between $x=3$ and 7 in Figure 3.22. These results are consistent with those inferred from the scorch intensity measures on the fire poles. Scorch intensities were greatest on the north to northwest and west sides while the lowest values were found along the northeast corner and southeast corners. The gravel road surrounding the barrier acted as a natural fire break and prevented the fire from spreading to the side slopes.

The fire lasted approximately 7 minutes by which time all of the imported fuel and most of the natural biomass had been consumed (Figure 3.23). A post-fire site inspection found all instrumentation to be in working order with no evidence of fire damage except for a small amount of singeing on the PVC jackets of the mini-rhizotrons. A thick, white crust of ash had formed across most of the site with large accumulations where larger shrubs were resident (Figure 3.24). Following completion of the fire on the surface of the barrier, attempts were made to ignite the north portion of the gravel side slope. The toe of the gravel side slope did not burn very well, perhaps due to the high-moisture conditions of the plant 
biomass and the low plant density that resulted in large open areas between plants. Basically, the fire consumed only the plants that were lit by the drip torch, but did not transfer between plants. Winds were also very mild and did not play a major factor in transporting the fire from plant colony to colony, with one exception (Figure 3.25). Note that no imported fuel was added to the side slope.

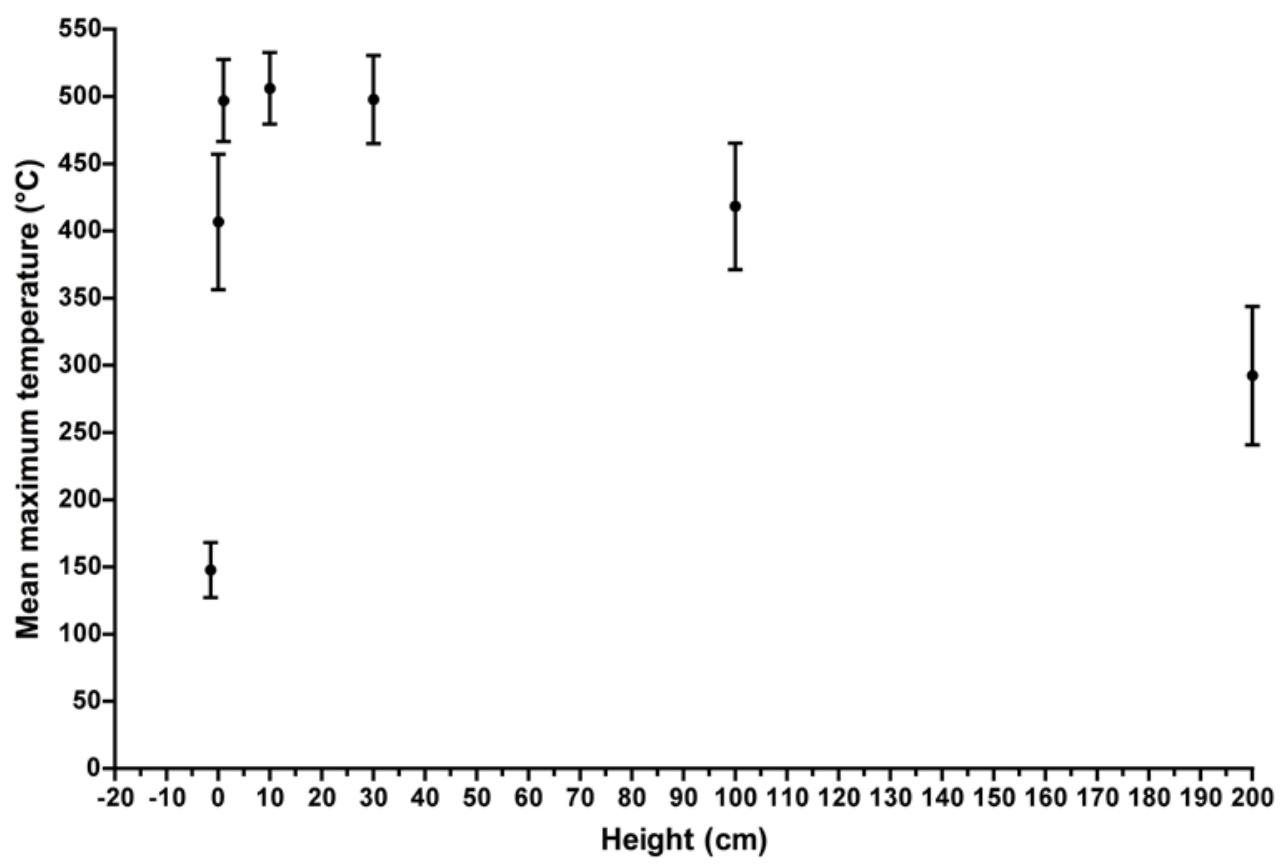

Figure 3.20. Relationship Between Mean Maximum Temperature and Height from about $1.5 \mathrm{~cm}$ Below Ground to $200 \mathrm{~cm}$ Above the Ground. Error bars are one standard error of the mean.

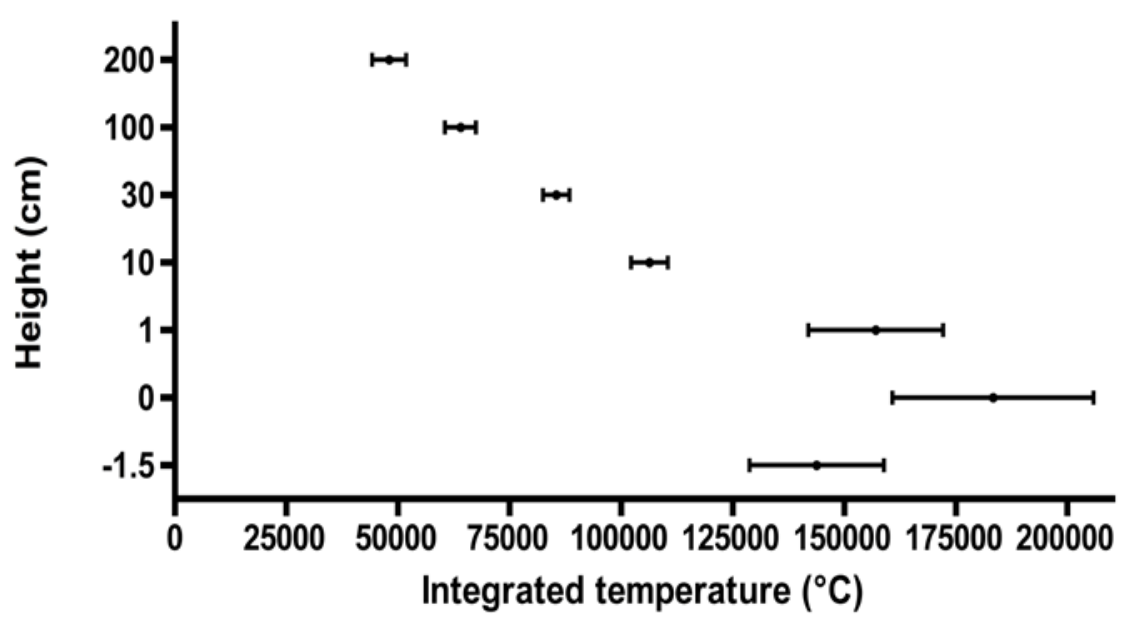

Figure 3.21. Duration of Elevated Temperature. Bars are one standard error of the mean. 
(a)

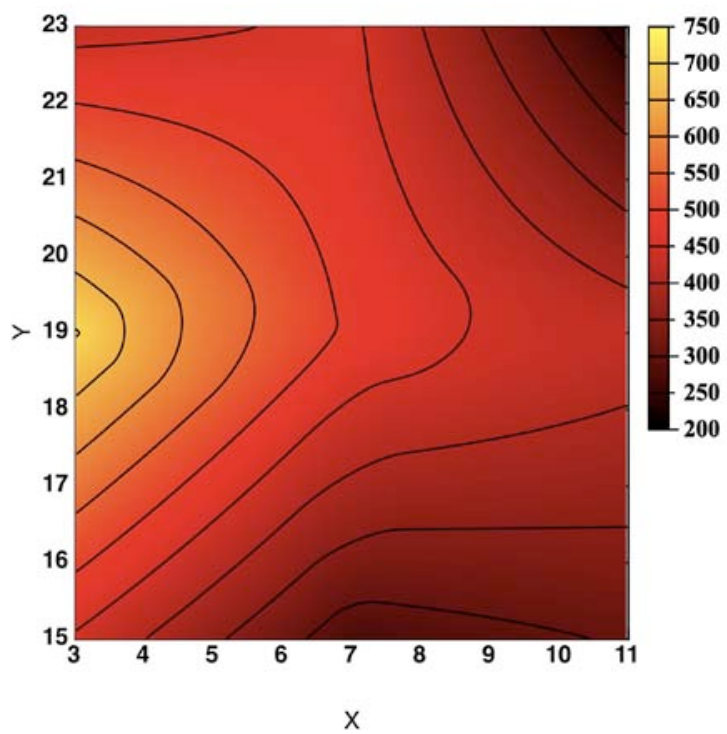

(b)

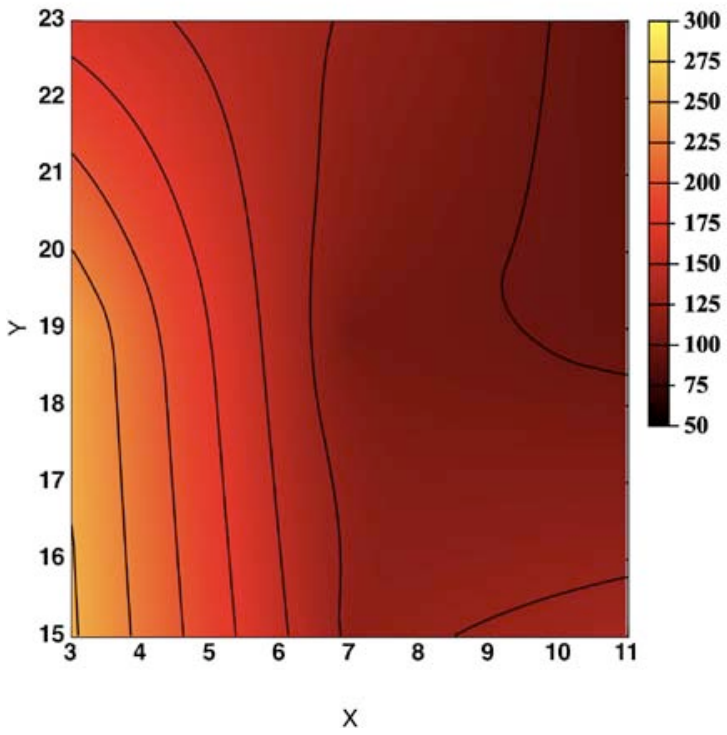

Figure 3.22. Peak Temperatures Observed on the Burnt Section of the Barrier: (a) Air Temperature Measured $100 \mathrm{~cm}$ Above the Surface and (b) Soil Temperature Measured $1.5 \mathrm{~cm}$ Below the Surface on the Burn Area. Unit is degree Celsius. 


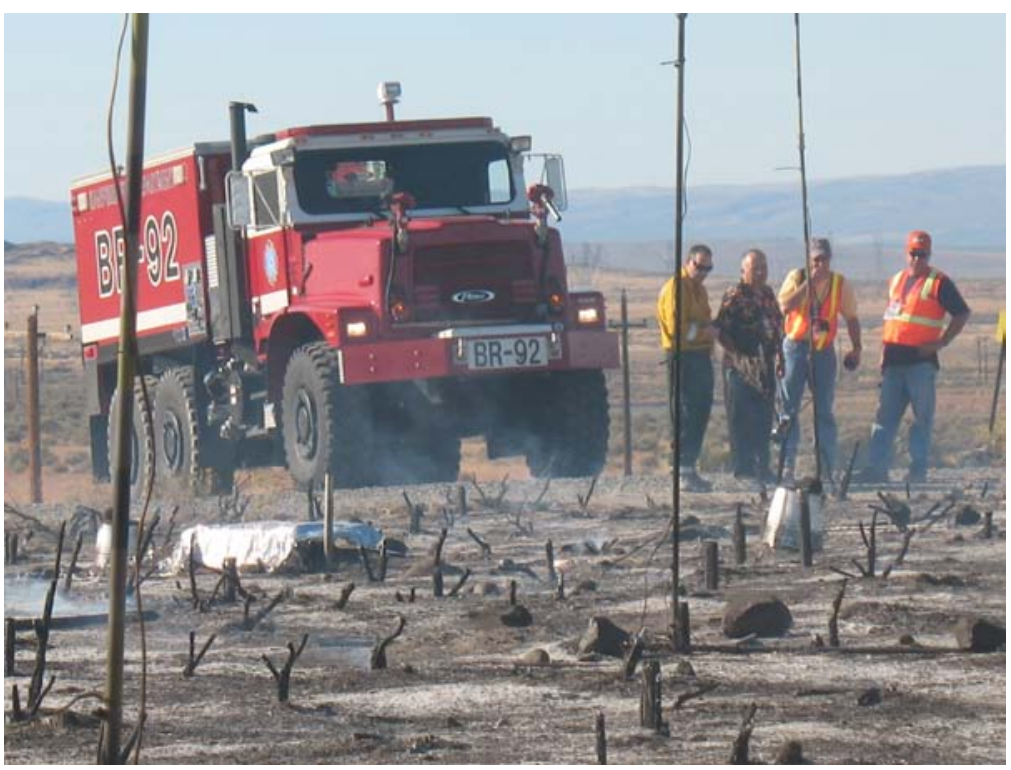

Figure 3.23. Surface of the Barrier at the End of the Fire. The fire lasted about 7 minutes.

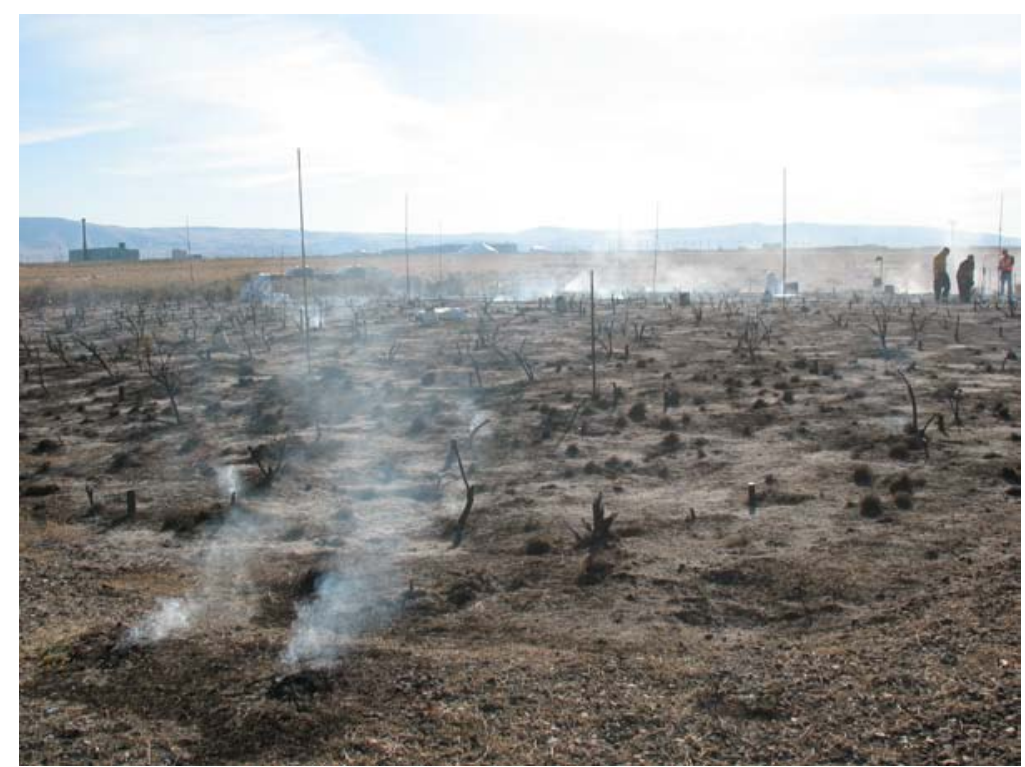

Figure 3.24. Surface of the Barrier at the End of the Fire Showing Sporadic White Ash Crust 


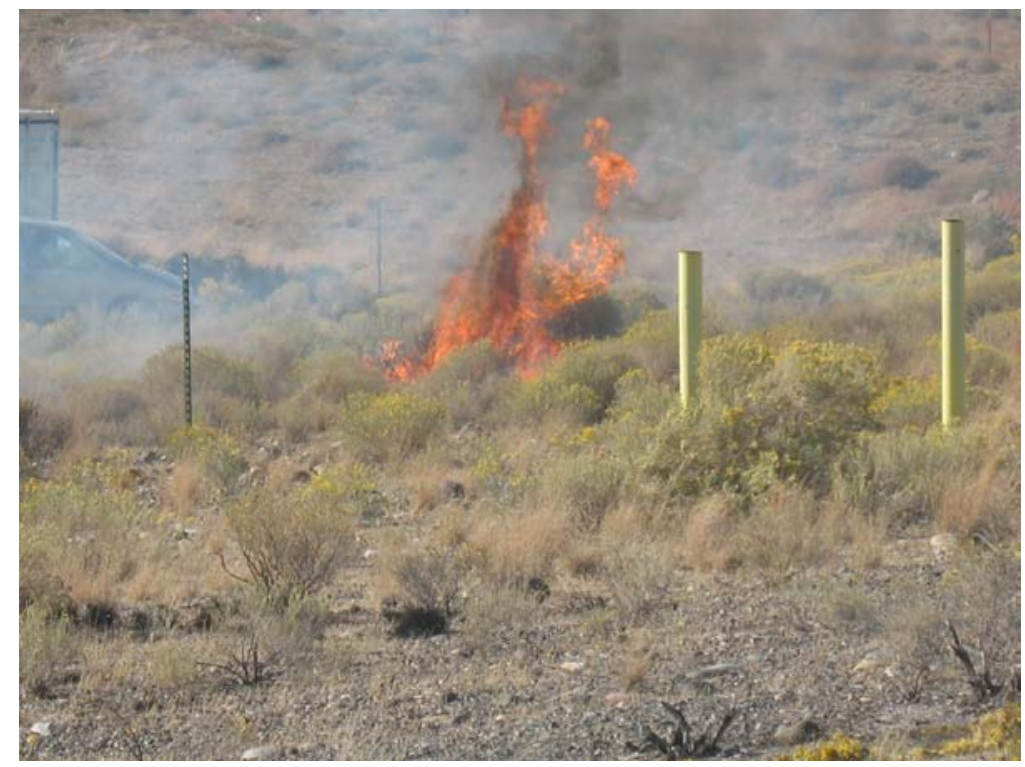

Figure 3.25. North Section of the Gravel Side Slope Under Fire. The sparse canopy and high moisture of the shrubs resulted in a very spotty burn.

\subsection{Surface Layer Composition and Inflation/Deflation}

Quantifying the near-surface particle size distribution, including gravel content, is one means by which inflationary or deflationary responses to fire can be determined. Figure 3.26 compares the mean particle size distribution of Warden silt loam, collected before the fire, with samples collected from the nine plots (Figure 2.6) one week after the fire. Visual inspection shows a decrease in the amount of clay and increase in the silt fraction.

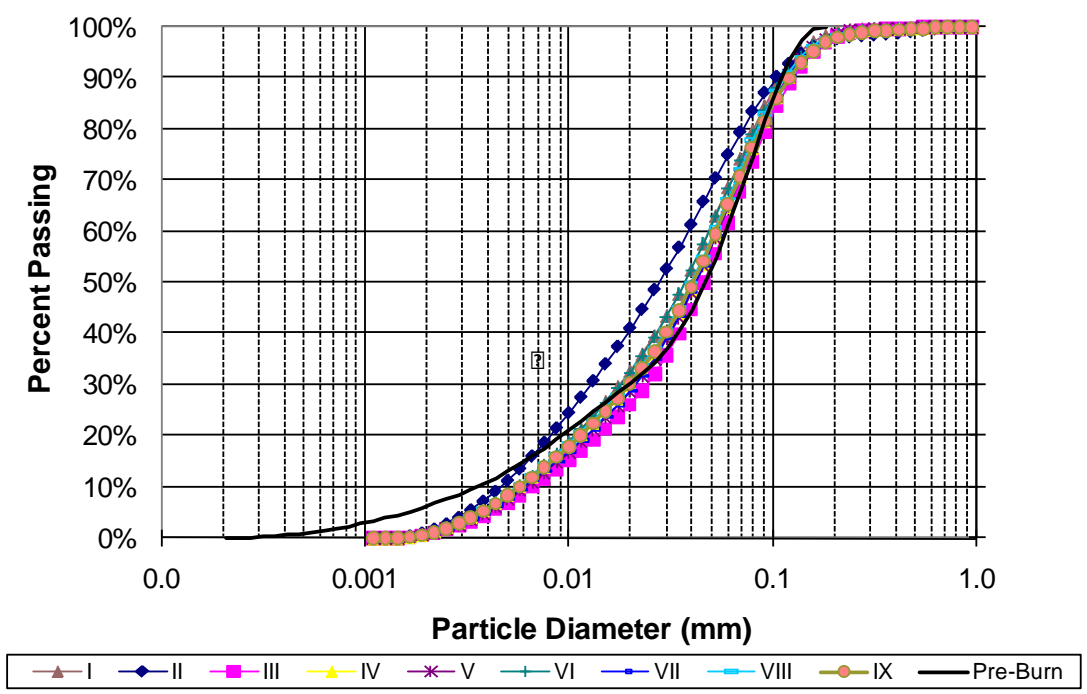

Figure 3.26. Distribution of Gravel from 0 to $2 \mathrm{~cm}$ Deep on Burnt Section: (a) Pre-Burn Gravel Content and (b) Difference Between Pre- and Post-Burn Content 
Table 3.15 confirms this observation. The pre-burn sample contained $11.4 \%$ clay, $51.2 \%$ silt, 37.3\% sand, and $0.009 \%$ coarse (> $2 \mathrm{~mm}$ ). In comparison, the post-burn sample contained an average of $7.5 \%$ clay, $69.2 \%$ silt, $23.2 \%$ sand, and $0.03 \%$ coarse. Table 3.15 shows a significant $(\alpha=0.05)$ reduction in the $\mathrm{C}_{\mathrm{u}}$ from the pre-burn samples (16.6) to the post-burn samples (6.6) suggested a transformation into a less well graded soil. The $\mathrm{C}_{\mathrm{u}}$ is a non-statistical measure of the size range of the particle-size distribution and is equivalent to the slope of the gradation curve. The larger the value of $\mathrm{C}_{\mathrm{u}}$, the larger the range of particle-size classes. For most natural soils, uniform samples typically show a $C_{u}$ less than 2 . A $C_{u}<4$ is indicative of a poor gradation, whereas $\mathrm{C}_{\mathrm{u}}>4$ is well graded, provided the gradation curve is monotonic and relatively symmetrical. The coefficient of curvature, $\mathrm{C}_{c}$, is also non-statistical measure of the shape and symmetry of a given particle-size distribution curve. It is sometimes referred to as the coefficient of gradation and is often used to confirm conclusions about the gradation inferred from the $\mathrm{C}_{\mathrm{u}}$. Table 3.15 shows that the mean $\mathrm{C}_{\mathrm{c}}$ decreased slightly from 1.48 in pre-burn samples to 1.32 in the post-burn samples. A soil is considered to be well graded if $C_{c}$ is between 1 and 3 . Table 3.15 also shows that the sediment collected from the runoff event was mostly sand (54\%) and silt (44\%) but was well graded $\left(\mathrm{C}_{\mathrm{c}}=1.47\right.$; $\mathrm{C}_{\mathrm{u}}=8.67$ ) with a mean diameter almost twice that of the pre-burn and post-burn samples. This is attributed to the larger amount of coarse materials comprised mostly of ash.

Figure 3.27a shows the post-burn distribution of gravel content in the 0 to $2 \mathrm{~cm}$ depth on the north section of the Barrier. Figure 3.27b shows the spatial differences in mean gravel content on the north section of the barrier. During construction, the top $1 \mathrm{~m}$ fine-soil surface layer of the barrier was amended by adding $15 \mathrm{wt} \%$ pea gravel as a means of protecting soil erosion (Ligotke 1994, Ward et al. 1997, DOE 1998). The mean pre-burn gravel content was $20 \pm 5.2 \%$ whereas the mean post-burn gravel content was $20.5 \pm 5.9 \%$. The difference between the pre- and post-burn gravel contents is not statistically significant. However, these values are significantly higher than the immediate post-construction values. The mean gravel content for the entire barrier in 1994 was $16.2 \pm 3.0 \%$; the $16.9 \pm 4.0 \%$ on the north (irrigated) side was not significantly different $(\alpha=0.05)$ from the $15.5 \pm 1.0 \%$ on the south (non-irrigated) side. At the end of the treatability test in 1997, mean gravel content for the entire barrier was $13.4 \pm 2.0 \%$, a significant decline from the 1994 value $(\alpha=0.05)$.

Therefore, there was no short-term effect of the fire on the near-surface composition as derived from gravel contents. The mean gravel content 15 years after construction $(20 \pm 5.2 \%)$ is significantly different from that at construction (16.2 $\pm 3.0 \%)$. Given the relatively small amount of soil collected from the surface in runoff (Gee et al. 1995; Ward et al. 2008) and from wind erosion (DOE 1999), the surface appears to have undergone some deflation over the last 15 years. During deflationary periods, nearsurface increases in gravel, relative to its bulk distribution, can be expected as soil particles are removed by water or wind and armor is formed. During inflationary periods, a layer of soil mostly free of gravel will form on the surface and gravel content will decrease relative to its bulk distribution.

Although gravel contents do not indicate any short-term inflationary pressures, there is circumstantial evidence that some soil may have been transported to the surface since the fire. Evidence of soil migration was observed after a snowfall on December 16, 2008 (Figure 3.28). Deposited soil is evident on the snow surface owing to its contrast with the bright snow found in footprints that were shielded from the deposition. Measurements with erosion pins show evidence of both inflation and deflation. The greatest change in elevation was about $13.5 \mathrm{~mm}$, and the greatest accumulation of soil was $18.5 \mathrm{~mm}$. The greatest change in elevation occurred on the northwest to the center of the burned area (Figure 3.29). The greatest increase in elevation or accumulation of soil occurred in the east side of the barrier surface. 
Table 3.15. Textural Composition and Particle Size Statistics for Pre- and Post-burn Samples.

\begin{tabular}{|c|c|c|c|c|c|c|c|c|c|c|c|c|c|c|c|}
\hline Sample & $\begin{array}{l}\text { Clay } \\
(\%)\end{array}$ & $\begin{array}{l}\text { Silt } \\
(\%)\end{array}$ & $\begin{array}{l}\text { Sand } \\
(\%)\end{array}$ & $\begin{array}{c}\text { Coarse } \\
(\%)\end{array}$ & $\mathrm{d}_{10}$ & $\mathrm{~d}_{16}$ & $\mathrm{~d}_{30}$ & $\mathrm{~d}_{50}$ & $\mathrm{~d}_{60}$ & $\mathrm{~d}_{84}$ & $\mathrm{C}_{\mathrm{c}}$ & $\mathrm{C}_{\mathrm{u}}$ & $\begin{array}{c}\mathrm{d}_{\mathrm{G}} \\
(\mathrm{mm})\end{array}$ & $\begin{array}{c}\text { Sorting } \\
\text { Coefficient } \\
\mathrm{S}_{\mathrm{G}} \\
\end{array}$ & $\begin{array}{c}\text { Specific } \\
\text { Surface } \\
\text { Area } \\
\left(\mathrm{m}^{2} / \mathrm{g}\right) \\
\end{array}$ \\
\hline Pre Burn & 11.4401 & 51.2180 & 37.3325 & 0.0094 & 0.0043 & 0.0074 & 0.0215 & 0.0604 & 0.0719 & 0.1095 & 1.4898 & 16.6047 & 0.0365 & 3.8595 & \\
\hline Post Burn- I & 7.5781 & 70.9427 & 21.4489 & 0.0302 & 0.0068 & 0.0108 & 0.0194 & 0.0337 & 0.0434 & 0.0936 & 1.2886 & 6.4297 & 0.0324 & 2.9498 & 7.6650 \\
\hline Post Burn II & 9.7772 & 71.8288 & 18.3055 & 0.0882 & 0.0051 & 0.0077 & 0.0140 & 0.0255 & 0.0341 & 0.0849 & 1.1229 & 6.6851 & 0.0256 & 3.3104 & 6.8970 \\
\hline Post Burn III & 6.5127 & 66.6782 & 26.7911 & 0.0180 & 0.0085 & 0.0139 & 0.0251 & 0.0424 & 0.0536 & 0.1077 & 1.3867 & 6.3133 & 0.0399 & 2.7850 & 9.9110 \\
\hline Post Burn IV & 7.4970 & 68.0834 & 24.3903 & 0.0294 & 0.0071 & 0.0117 & 0.0216 & 0.0377 & 0.0484 & 0.1029 & 1.3638 & 6.8534 & 0.0356 & 2.9714 & 8.0670 \\
\hline Post Burn V & 6.9935 & 68.6288 & 24.3560 & 0.0217 & 0.0076 & 0.0124 & 0.0226 & 0.0386 & 0.0492 & 0.1015 & 1.3590 & 6.4333 & 0.0365 & 2.8566 & 8.0910 \\
\hline Post Burn VI & 7.6034 & 70.3112 & 22.0492 & 0.0361 & 0.0067 & 0.0107 & 0.0194 & 0.0340 & 0.0439 & 0.0961 & 1.2798 & 6.5374 & 0.0327 & 2.9965 & 8.6420 \\
\hline Post Burn VII & 7.0248 & 68.7142 & 24.2392 & 0.0218 & 0.0076 & 0.0124 & 0.0225 & 0.0385 & 0.0490 & 0.1011 & 1.3587 & 6.4431 & 0.0364 & 2.8596 & 5.3250 \\
\hline Post Burn VIII & 7.5971 & 69.2256 & 23.1494 & 0.0279 & 0.0069 & 0.0113 & 0.0208 & 0.0361 & 0.0464 & 0.0987 & 1.3479 & 6.7333 & 0.0343 & 2.9581 & 3.1550 \\
\hline Post Burn IX & 7.4013 & 68.2160 & 24.3480 & 0.0347 & 0.0071 & 0.0115 & 0.0213 & 0.0372 & 0.0480 & 0.1034 & 1.3296 & 6.7722 & 0.0354 & 2.9942 & 7.6450 \\
\hline Runoff & 1.7801 & 43.9163 & 53.9506 & 0.3519 & 0.0129 & 0.0219 & 0.0460 & 0.0846 & 0.1119 & 0.2682 & 1.4661 & 8.6706 & 0.0792 & 3.5006 & NA \\
\hline
\end{tabular}



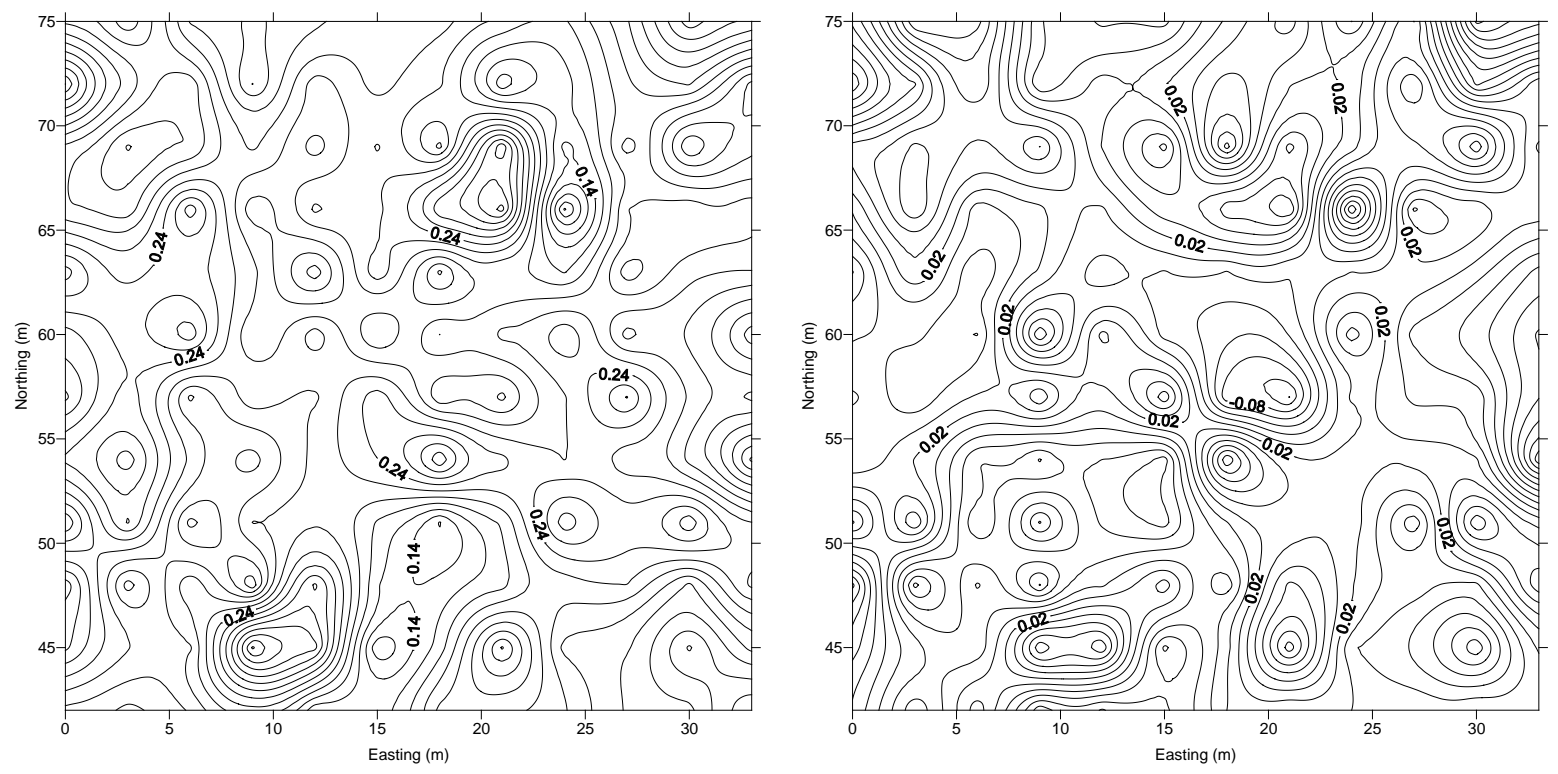

Figure 3.27. Distribution of Gravel from 0 to $2 \mathrm{~cm}$ Deep on Burnt Section: (a) Pre-Burn Gravel Content and (b) Difference Between Pre- and Post-Burn Content

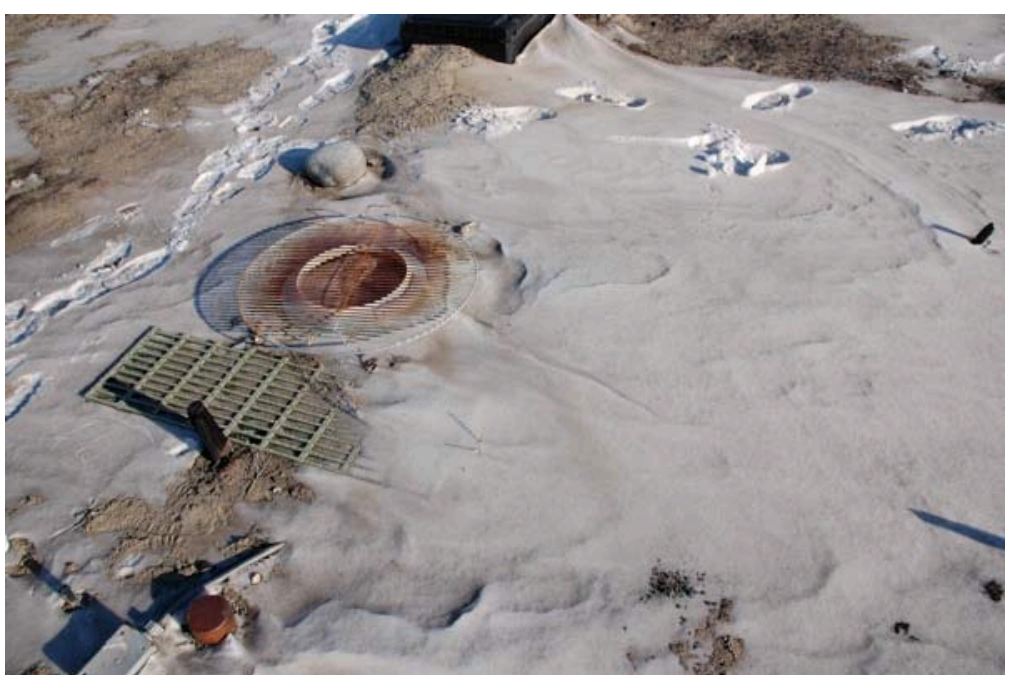

Figure 3.28. Soil Deposition Patterns on a Snow-Covered Surface on December 16, 2008 


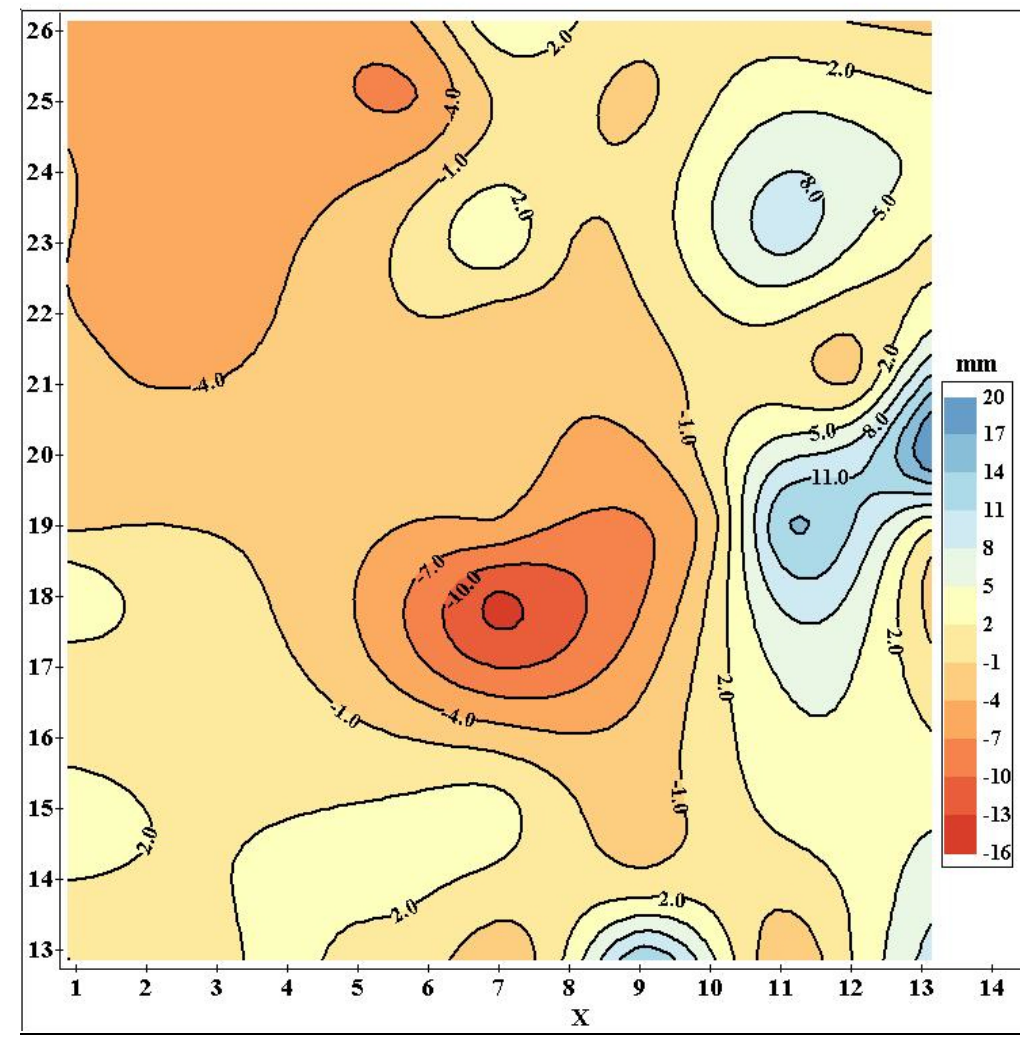

Figure 3.29. Soil Inflation and Deflation Patterns on the Burned Area. The $X$ and $Y$ edges denote positions on the surface. The distance between coordinate values is 3 meters.

These changes may be due to localized redistribution of soil from the burned area. In spite of the absence of significant short-term changes resulting from the fire, the large change over the last 15 years is indicative what possible changes that may occur on the burned surface. During the period of monitoring for the treatability test, very little erosion was observed. The only measurable loss of soil by wind occurred during the first 3 months when the surface was bare with estimates ranging from 7.4 to 744 $\mathrm{mg} / \mathrm{m}^{2}$ (DOE 1999). This loss of fine soil was sufficient to initiate the formation of gravel armor in some places, which coupled with establishment of vegetation on the surface, essentially eliminated further soil loss. Differences in gravel content between the north and south sections were also partly attributed to deflation resulting from the simulated 1,000-year return precipitation events on the north and partly due to freeze-thaw processes. Field tests at Hanford show that unprotected silt loam is very susceptible to rainsplash erosion as it does not contain enough coarse material to initiate the development of surface armor (Gilmore and Walters 1993). Although use of a gravel admix on unvegetated silt loam reduced, but did not eliminate, erosion, a silt-loam-gravel admix, combined with a vegetative cover, such as used on the prototype barrier, can reduce sediment yields by a factor of 10 to 100 (Gilmore and Walters 1993). Postburn conditions are now very similar to those immediately after construction when the surface was bare with little protection from raindrop impact. Thus, the surface will face increased deflationary pressures that could lead to further increases in gravel in the near surface.

Long-term freeze-thaw cycles, when coupled with the development of root biomass, could have an impact on the soil bulk density in the near surface. Figure 3.30a shows the pre-burn distribution of dry bulk density based on surface nuclear density measurements on the north section of the Barrier. Figure 3.30b shows the spatial differences between the pre-burn and post-burn condition. The mean dry 

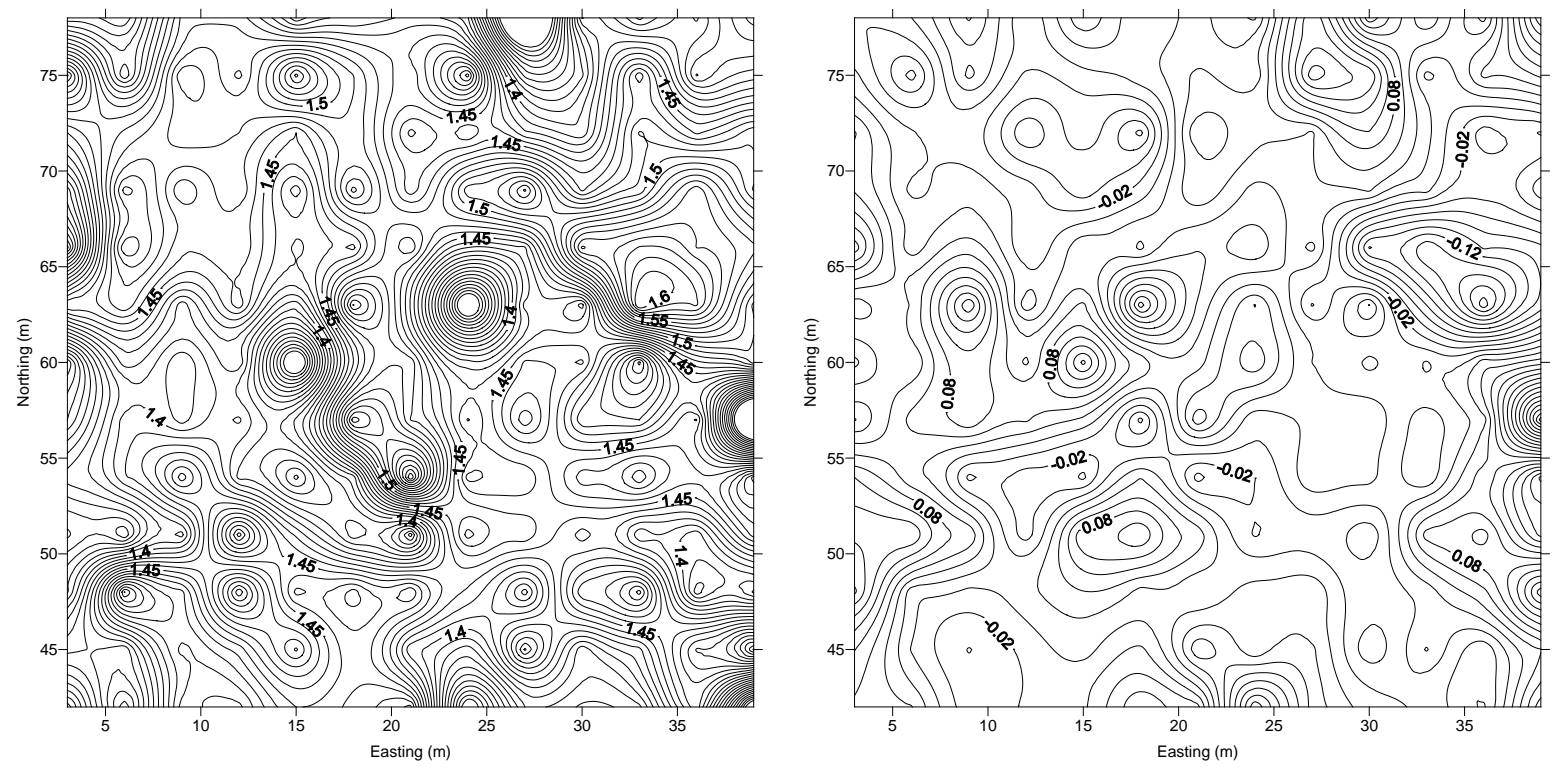

Figure 3.30. Distribution of Dry Bulk Density on Burnt Section: (a) Pre-Burn Bulk Density and (b) Difference Between Pre- and Post-Burn Density

density immediately after construction was $1.87 \pm 0.072 \mathrm{~g} / \mathrm{cm}^{3}$. The mean pre-burn dry bulk density on the north section was $1.46 \pm 0.054 \mathrm{~g} / \mathrm{cm}^{3}$ whereas the mean post-burn density was $1.442 \pm 0.07 \mathrm{~g} / \mathrm{cm}^{3}$. The density decreased by a mean of $0.026 \pm 0.07 \mathrm{~g} / \mathrm{cm}^{3}$ in response to the fire. These changes were largest near sagebrush stumps, suggesting that they appear to be consistent with the location of large ash accumulations on the surface. Nonetheless, the short-term decrease in dry bulk density is not statistically significant.

\subsection{Fire Effects on Soil Water Repellency}

Soil water repellency was measured in the laboratory on soil samples and in the field. In situ and laboratory water repellency measurements before the burn resulted in water-drop penetration times all less than 5 seconds, which is indicative of wettable soils. Immediately after the burn and for 2 months after, field and laboratory measurements showed a significant decrease in wettabilty (Table 3.15). Figure 3.31 shows a photograph taken in the field during a water-drop penetration test after the fire. Water drops penetrated immediately into wettable soils, which were typically bare soil areas (no evidence of plants) and ash-free zones (free of organic matter before the fire). Water-drop penetration tests near shrubs suggested the presence of water-repellant soils with repellency ranging from slightly water repellant to strongly water repellant (Figure 3.31).

In general, water repellant conditions in unburned areas were found in the leaf litter and at the surface immediately beneath shrubs, before the fire. After the fire, water repellant areas were typically found parallel to the surface but at deeper depths. Data analysis is still in progress to establish relationships between water repellency and soil temperatures observed during the fire. Analysis to date suggests some general relationships between soil temperature and water repellency: 1) essentially no change in water repellency when temperatures were less than $200^{\circ} \mathrm{C}$, 2) strong water repellency when soil temperatures 


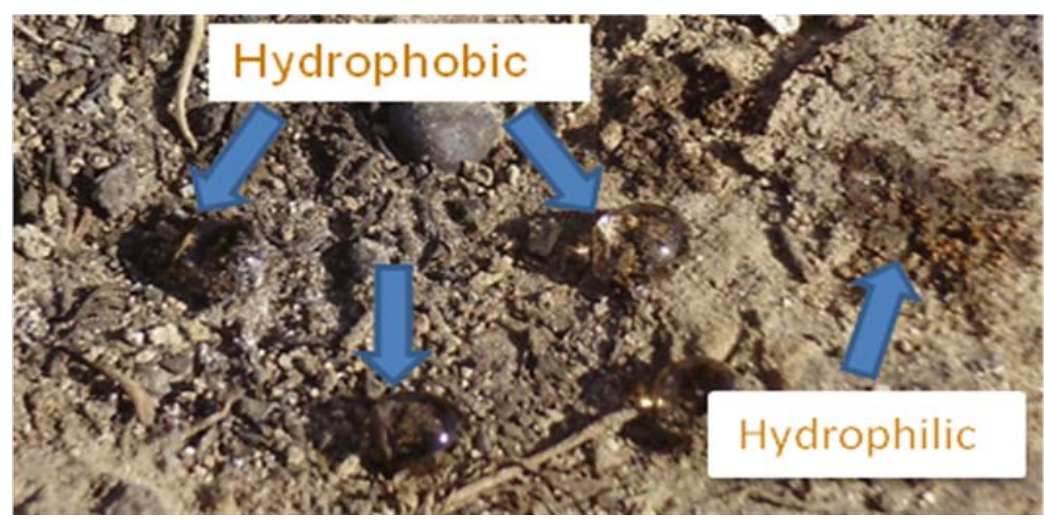

Figure 3.31. Photograph of Burned Surface During Water Drop Penetration Test

were between 200 and $250^{\circ} \mathrm{C}$, and (3) absence of water repellency when soil temperatures between 250 and $400^{\circ} \mathrm{C}$ were recorded. These ranges are consistent with those reported by Debano (2000).

Soil water repellency is reversible and can disappear when the soil is wet, often returning after the soil dries out. Measurements taken over time showed that the intense snowfall in the winter of 2008 resulted in a loss of water repellency by early January 2009, and repellency remained relatively low throughout the winter (Table 3.16). Measurements made nearly a year later when the soil surface was quite dry again and showed evidence of reduced wettability. After 1 year, hydrophobicity has mostly returned to pre-burn levels with only $16 \%$ of samples still showing signs of decreased wettability (Table 3.17). Thus, elevated water repellency may persist for at least 1 year under Hanford conditions for fires occurring in the late summer. Measurements will continue to determine the time needed for fireinduced soil water repellency to dissipate. Published reports suggest that the time to dissipate can range from less than 1 year (Huffman et al. 2001) to over 6 years (Dyrness 1976).

Although the water-drop penetration test is the most common method for measuring water repellency, the test can be somewhat subjective for soils with intermediate wettabilty. Under such conditions, the water drop can sit on the soil surface long enough to collapse, making it impossible to determine whether infiltration actually occurred. Robichaud et al. (2008) reported success with a mini disk infiltrometer for determining wettability under such conditions. The two methods were compared at the 200-BP-1 barrier following the burn. Figure 3.32 shows the relationship between the infiltration rate from the mini-disk infiltrometer and the water-drop penetration test. These data show an exponential decrease in infiltration rate as water repellency increased. The mini-disk infiltrometer measurement takes less time, is less subjective, and has the added advantage of providing a measure of unsaturated hydraulic conductivity. Analyses are ongoing to establish a relationship between severity of repellency and infiltration rate.

These observations are also of significance to the runoff response of the barrier. Robichaud (2000) suggested that under fire-induced water-repellent conditions, runoff rates should quickly peak and then begin declining as the hydrophobic substances of the soil are broken down, thus increasing infiltration over time. He also showed that before a severe burn occurs, little water repellency should exist within the soil. Thus, rainfall simulation tests will be conducted to characterize infiltration rates and surface runoff. There is a paucity of runoff data for the Hanford site collected under well defined or controlled conditions, and this complicates the calibration of models for predicting barrier performance. Before the fire, runoff had been recorded at the barrier on only two occasions, once when the surface was bare, and 
Table 3.16. Effect of Fire on Soil Water Repellency Measured in the Laboratory

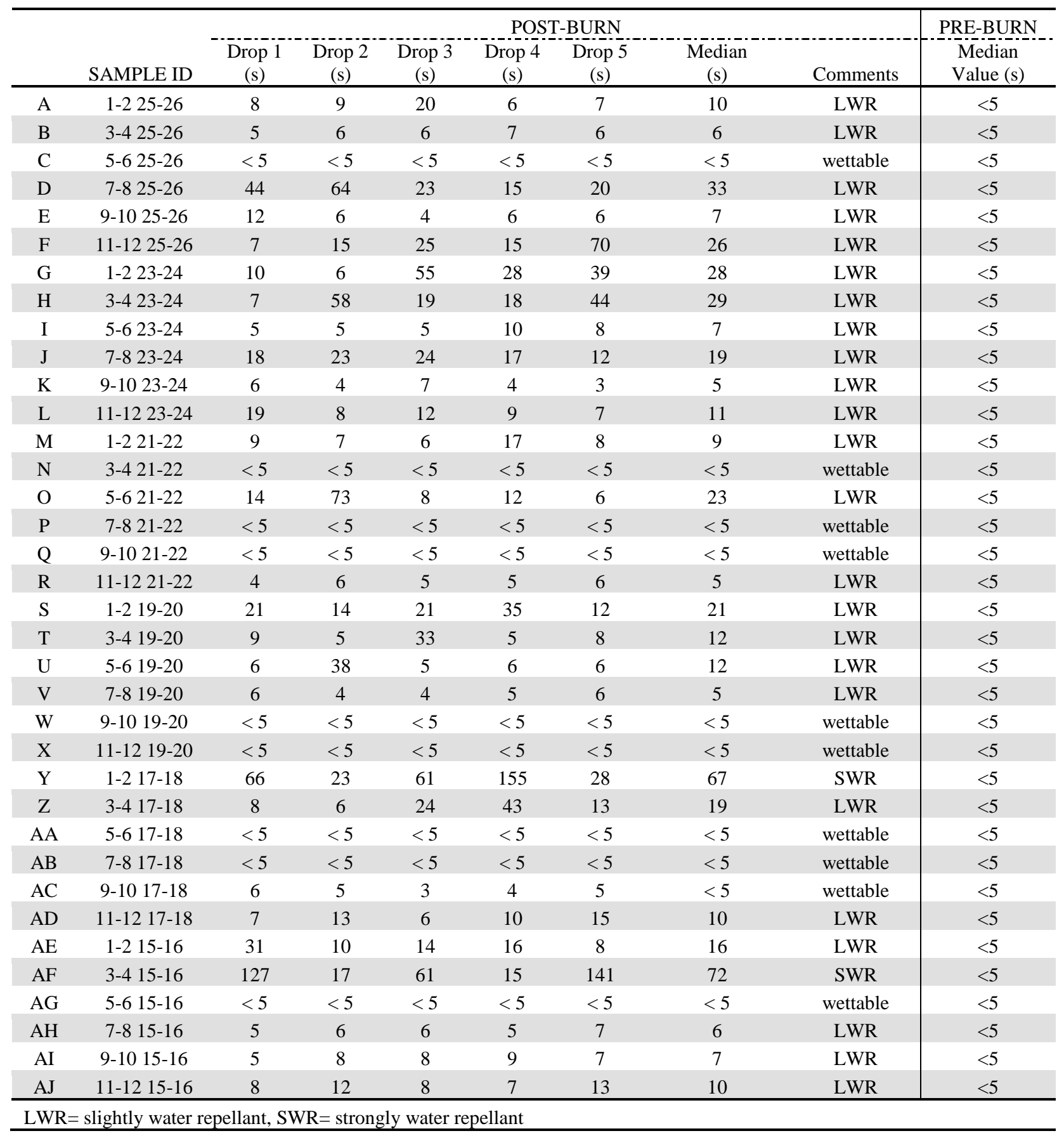


Table 3.17. Soil Water Repellency Measured in the Laboratory 4 Months After the Fire

\begin{tabular}{|c|c|c|}
\hline & SAMPLE ID & $\begin{array}{l}\text { Median Value } \\
\text { (s) }\end{array}$ \\
\hline A & $1-225-26$ & $<5$ \\
\hline B & $3-425-26$ & $<5$ \\
\hline $\mathrm{C}$ & 5-6 25-26 & $<5$ \\
\hline $\mathrm{D}$ & $7-8$ 25-26 & $<5$ \\
\hline $\mathrm{E}$ & $9-1025-26$ & $<5$ \\
\hline $\mathrm{F}$ & $11-12$ 25-26 & $<5$ \\
\hline G & $1-223-24$ & $<5$ \\
\hline $\mathrm{H}$ & $3-423-24$ & $<5$ \\
\hline I & 5-6 23-24 & $<5$ \\
\hline $\mathrm{J}$ & $7-8$ 23-24 & $<5$ \\
\hline K & $9-10$ 23-24 & $<5$ \\
\hline $\mathrm{L}$ & $11-12$ 23-24 & $<5$ \\
\hline M & 1-2 21-22 & $<5$ \\
\hline $\mathrm{N}$ & $3-4$ 21-22 & $<5$ \\
\hline $\mathrm{O}$ & 5-6 21-22 & $<5$ \\
\hline$P$ & $7-8$ 21-22 & $<5$ \\
\hline Q & $9-10$ 21-22 & $<5$ \\
\hline $\mathrm{R}$ & $11-12$ 21-22 & $<5$ \\
\hline $\mathrm{S}$ & $1-2$ 19-20 & $<5$ \\
\hline $\mathrm{T}$ & $3-4$ 19-20 & $<5$ \\
\hline $\mathrm{U}$ & $5-619-20$ & $<5$ \\
\hline $\mathrm{V}$ & $7-8$ 19-20 & $<5$ \\
\hline W & $9-10$ 19-20 & $<5$ \\
\hline $\mathrm{X}$ & $11-12$ 19-20 & $<5$ \\
\hline $\mathrm{Y}$ & $1-217-18$ & $<5$ \\
\hline $\mathrm{Z}$ & $3-4$ 17-18 & $<5$ \\
\hline AA & 5-6 17-18 & $<5$ \\
\hline $\mathrm{AB}$ & 7-8 17-18 & $<5$ \\
\hline $\mathrm{AC}$ & $9-10$ 17-18 & $<5$ \\
\hline $\mathrm{AD}$ & $11-12$ 17-18 & $<5$ \\
\hline $\mathrm{AE}$ & $1-215-16$ & $<5$ \\
\hline $\mathrm{AF}$ & $3-415-16$ & $<5$ \\
\hline$A G$ & 5-6 15-16 & $<5$ \\
\hline $\mathrm{AH}$ & $7-8$ 15-16 & $<5$ \\
\hline $\mathrm{AI}$ & $9-10$ 15-16 & $<5$ \\
\hline $\mathrm{AJ}$ & $11-12$ 15-16 & $<5$ \\
\hline
\end{tabular}


Table 3.18. Soil Water Repellency Measured in the Laboratory 1 Year After the Fire

\begin{tabular}{|c|c|c|c|c|c|c|c|c|c|}
\hline & \multirow[b]{2}{*}{ SAMPLE ID } & \multirow[b]{2}{*}{$\begin{array}{c}\text { Drop } 1 \\
\text { (s) }\end{array}$} & \multicolumn{6}{|c|}{ POST-BURN } & \multirow{2}{*}{$\begin{array}{c}\text { PRE-BURN } \\
\text { Median } \\
\text { Value (s) }\end{array}$} \\
\hline & & & $\begin{array}{c}\text { Drop } 2 \\
\text { (s) }\end{array}$ & $\begin{array}{c}\text { Drop } 3 \\
\text { (s) }\end{array}$ & $\begin{array}{c}\text { Drop } 4 \\
\text { (s) }\end{array}$ & $\begin{array}{c}\text { Drop } 5 \\
\text { (s) }\end{array}$ & Median (s) & Wettability & \\
\hline A & $1-225-26$ & 8 & 9 & 20 & 6 & 7 & 10 & LWR & $<5$ \\
\hline B & $3-425-26$ & 5 & 6 & 6 & 7 & 6 & 6 & LWR & $<5$ \\
\hline C & $5-625-26$ & $<5$ & $<5$ & $<5$ & $<5$ & $<5$ & $<5$ & wettable & $<5$ \\
\hline D & $7-825-26$ & 44 & 64 & 23 & 15 & 20 & 33 & LWR & $<5$ \\
\hline E & $9-1025-26$ & 12 & 6 & 4 & 6 & 6 & 7 & LWR & $<5$ \\
\hline F & $11-1225-26$ & 7 & 15 & 25 & 15 & 70 & 26 & LWR & $<5$ \\
\hline G & $1-223-24$ & 10 & 6 & 55 & 28 & 39 & 28 & LWR & $<5$ \\
\hline $\mathrm{H}$ & $3-423-24$ & 7 & 58 & 19 & 18 & 44 & 29 & LWR & $<5$ \\
\hline I & $5-623-24$ & 5 & 5 & 5 & 10 & 8 & 7 & LWR & $<5$ \\
\hline $\mathrm{J}$ & 7-8 23-24 & 18 & 23 & 24 & 17 & 12 & 19 & LWR & $<5$ \\
\hline K & $9-1023-24$ & 6 & 4 & 7 & 4 & 3 & 5 & LWR & $<5$ \\
\hline $\mathrm{L}$ & $11-12$ 23-24 & 19 & 8 & 12 & 9 & 7 & 11 & LWR & $<5$ \\
\hline M & $1-2$ 21-22 & 9 & 7 & 6 & 17 & 8 & 9 & LWR & $<5$ \\
\hline $\mathrm{N}$ & $3-421-22$ & $<5$ & $<5$ & $<5$ & $<5$ & $<5$ & $<5$ & wettable & $<5$ \\
\hline $\mathrm{O}$ & $5-621-22$ & 14 & 73 & 8 & 12 & 6 & 23 & LWR & $<5$ \\
\hline $\mathrm{P}$ & $7-8$ 21-22 & $<5$ & $<5$ & $<5$ & $<5$ & $<5$ & $<5$ & wettable & $<5$ \\
\hline $\mathrm{Q}$ & $9-1021-22$ & $<5$ & $<5$ & $<5$ & $<5$ & $<5$ & $<5$ & wettable & $<5$ \\
\hline $\mathrm{R}$ & $11-1221-22$ & 4 & 6 & 5 & 5 & 6 & 5 & LWR & $<5$ \\
\hline S & 1-2 19-20 & 21 & 14 & 21 & 35 & 12 & 21 & LWR & $<5$ \\
\hline $\mathrm{T}$ & $3-4$ 19-20 & 9 & 5 & 33 & 5 & 8 & 12 & LWR & $<5$ \\
\hline $\mathrm{U}$ & 5-6 19-20 & 6 & 38 & 5 & 6 & 6 & 12 & LWR & $<5$ \\
\hline $\mathrm{V}$ & 7-8 19-20 & 6 & 4 & 4 & 5 & 6 & 5 & LWR & $<5$ \\
\hline W & $9-10$ 19-20 & $<5$ & $<5$ & $<5$ & $<5$ & $<5$ & $<5$ & wettable & $<5$ \\
\hline $\mathrm{X}$ & $11-1219-20$ & $<5$ & $<5$ & $<5$ & $<5$ & $<5$ & $<5$ & wettable & $<5$ \\
\hline $\mathrm{Y}$ & 1-2 17-18 & 66 & 23 & 61 & 155 & 28 & 67 & SWR & $<5$ \\
\hline $\mathrm{Z}$ & $3-4$ 17-18 & 8 & 6 & 24 & 43 & 13 & 19 & LWR & $<5$ \\
\hline AA & 5-6 17-18 & $<5$ & $<5$ & $<5$ & $<5$ & $<5$ & $<5$ & wettable & $<5$ \\
\hline $\mathrm{AB}$ & $7-8$ 17-18 & $<5$ & $<5$ & $<5$ & $<5$ & $<5$ & $<5$ & wettable & $<5$ \\
\hline AC & $9-10$ 17-18 & 6 & 5 & 3 & 4 & 5 & $<5$ & wettable & $<5$ \\
\hline $\mathrm{AD}$ & $11-12$ 17-18 & 7 & 13 & 6 & 10 & 15 & 10 & LWR & $<5$ \\
\hline $\mathrm{AE}$ & 1-2 15-16 & 31 & 10 & 14 & 16 & 8 & 16 & LWR & $<5$ \\
\hline $\mathrm{AF}$ & $3-4$ 15-16 & 127 & 17 & 61 & 15 & 141 & 72 & SWR & $<5$ \\
\hline AG & $5-615-16$ & $<5$ & $<5$ & $<5$ & $<5$ & $<5$ & $<5$ & wettable & $<5$ \\
\hline $\mathrm{AH}$ & 7-8 15-16 & 5 & 6 & 6 & 5 & 7 & 6 & LWR & $<5$ \\
\hline AI & ـ & .5 & 8. & 8 & . & 7 & 7 & LWR & $<5$ \\
\hline
\end{tabular}




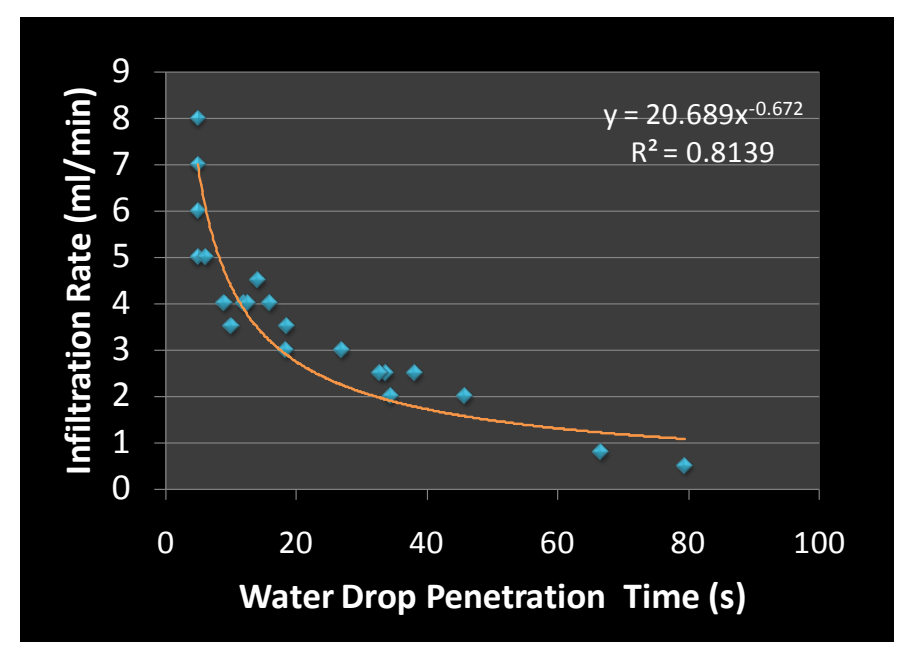

Figure 3.32. Relationship Between Infiltration Rate from a Mini-Disk Infiltrometer and Water Drop Penetration Tests

once after a rapid snowmelt event on frozen surface soil. Runoff from the barrier runoff plot $(10 \mathrm{ft} \times 50 \mathrm{ft})$ in 1995 after a 1000-yr simulated storm amounted to $2 \%$ of the applied precipitation $(1.79 \mathrm{~mm})$ with very little sediment loss. In the winter of 1997, Chinook winds on frozen soil resulted in $36.3 \mathrm{~mm}$ with no sediment loss. In January 2009, following the fire, a total of 1.6 liters of runoff was recorded. This is equivalent to $0.016 \mathrm{~mm}$, quite small compared to previous events, but the first observed in over 15 years, and this can be attributed directly to the effects of the fire.

\subsection{Fire Effects on Hydraulic Conductivity}

The comparison of the water-drop penetration test and infiltration rates measured by the mini-disk infiltrometer suggests a correlation between hydraulic conductivity and water repellency. Such a relationship was investigated by measuring saturated hydraulic conductivity and the unsaturated hydraulic conductivity on the north section before and after the burn. Both measurements were made in situ with the Guelph permeameter with one-head and two-head analyses and with the Guelph tension infiltrometer. Both methods allowed the alpha parameter to be calculated, which is the inverse of the bubbling pressure.

Table 3.18 summarizes the hydraulic properties derived from the field measurements. The mean preburn alpha was $0.085 \mathrm{~cm}^{-1}\left(0.216 \mathrm{in}^{-1}\right)$, which is equivalent to an air entry pressure of about $12 \mathrm{~cm}$ (4.7 in.). This value is somewhat small for a silt loam but is consistent with a field soil with welldeveloped structure, including the presence of macropores, and is likely influenced by the gravel in the near-surface. Field measurements of the unsaturated hydraulic conductivity $(\mathrm{K}(\psi))$ are necessary for characterizing many aspects of unsaturated water flow, including infiltration and runoff. Estimates of the field-saturated hydraulic conductivity, $\mathrm{K}_{\mathrm{fs}}$, derived from the tension infiltrometer showed a mean of $1.33 \times 10^{-3} \mathrm{~cm} / \mathrm{s} 3.77$ (ft/day) with a standard error of 0.009 . This value is roughly one order of magnitude larger than the saturated hydraulic conductivity measured in the laboratory on repacked siltloam samples before constructing the barrier. The one-head and two-head $\mathrm{K}_{\mathrm{fs}}$ measurements made with the Guelph permeameter are remarkably similar given the variability typically found in hydraulic conductivity measurements. Nonetheless, these data provide a good reference point for quantifying the 
effects of fire. The specific surface area, which controls sorption and the hyper-dry region of the moisture retention function, was also measured. As shown in Table 3.18, the mean value for the surface soil, sieved to pass a 2-mm (0.08-in.) sieve, was $9.915 \mathrm{~m}^{2} / \mathrm{g}$. This value compares well with independent measurements that range from 8 to $11 \mathrm{~m}^{2} / \mathrm{g}$.

Pre- and post-burn estimates of the field-saturated hydraulic conductivity, $\mathrm{K}_{\mathrm{fs}}$, and the alpha parameter are shown in Figure 3.33 and Figure 3.34, respectively. Field-saturated hydraulic conductivity decreased from pre-burn values, suggesting a reduction of the volume fraction of large pores or in porosity. Such a change is consistent with the loss of structure that would accompany a loss in organic matter. Measurements of $\mathrm{K}_{\mathrm{fs}}$ obtained 1 year after the fire show that $\mathrm{K}_{\mathrm{fs}}$ had returned to pre-burn conditions at only three out of eight measurement locations. Plots 1, 3, and 7 (Figure 2.6) showed essentially the same $\mathrm{K}_{\mathrm{fs}}$ values as before the fire whereas Plots 2, 4, 5, 6, and 8 all showed the reduced $\mathrm{K}_{\mathrm{fs}}$ observed after the fire.

During the first week, the post-fire estimates of the alpha parameter also decreased from pre-fire conditions (Figure 3.34). The inverse of the alpha parameter is a measure of the air entry pressure, and a decrease in alpha is essentially equivalent to an increase in the air entry pressure. This can be expected with a decrease in mean pore size or an increase in fines content. The only reasonable explanation for such an increase could be pore plugging due to an increase in ash in the near-surface layers. Estimates of alpha derived from tension infiltrometer measurements 1 year later show also show that only three out of eight plots had returned to pre-burn values (Plots 1, 3, and 7) whereas five (Figure 2.6) showed essentially the same $\mathrm{K}_{\mathrm{fs}}$ values as before the fire. The remaining five were at or near the values measured immediately after the fire. Both $\mathrm{K}_{\mathrm{fs}}$ and alpha are strongly influenced by pore-size distribution and therefore soil structure. It is clear that for the Warden silt loam used at the barrier, 1 year is too soon to see a regeneration of the structure loss due to the fire. This is not unexpected as the regeneration of structure will depend on the ground cover and organic matter derived from plant biomass. 
Table 3.19. Effect of Fire on Soil Physical and Hydraulic Properties After Fire

\begin{tabular}{|c|c|c|c|c|c|c|c|}
\hline Variable & Sampling & Mean & Variance & D.F & $\mathrm{t}_{\mathrm{stat}}$ & $\begin{array}{c}\mathrm{P}(\mathrm{T} \leq \mathrm{t}) \\
\text { Two-Tail }\end{array}$ & $\begin{array}{c}\mathrm{t}_{\text {crit }} \\
\text { Two-Tail }\end{array}$ \\
\hline \multirow{3}{*}{ Penetration Time (s) } & Pre-burn & $<5.000$ & 0.000 & \multirow{3}{*}{34} & \multirow{3}{*}{-3.812} & \multirow{3}{*}{0.001} & \multirow{3}{*}{2.032} \\
\hline & Post-burn & 14.394 & 260.279 & & & & \\
\hline & 1 yr Post-burn & 14.272 & 253.379 & & & & \\
\hline \multirow{3}{*}{ Gravel Content (\%) } & Pre-burn & 0.201 & 0.003 & \multirow{3}{*}{279} & \multirow{3}{*}{-0.646} & \multirow{3}{*}{0.519} & \multirow{3}{*}{1.969} \\
\hline & Post-burn & 0.205 & 0.004 & & & & \\
\hline & 1 yr Post-burn & 0.200 & 0.004 & & & & \\
\hline \multirow{3}{*}{ aalpha $(1 / \mathrm{cm})$} & Pre-burn & 0.083 & $7.88 \mathrm{E}-04$ & \multirow{3}{*}{10} & \multirow{3}{*}{1.284} & \multirow{3}{*}{0.228} & \multirow{3}{*}{2.228} \\
\hline & Post-burn & 0.065 & $3.41 \mathrm{E}-04$ & & & & \\
\hline & 1 yr Post-burn & 0.064 & 4.36E-04 & & & & \\
\hline \multirow{3}{*}{${ }^{\mathrm{a}} \mathrm{K}_{\mathrm{fs}}(\mathrm{cm} / \mathrm{s})$} & Pre-burn & $1.36 \mathrm{E}-03$ & $1.13 \mathrm{E}-07$ & \multirow{3}{*}{6} & \multirow{3}{*}{4.038} & \multirow{3}{*}{0.007} & \multirow{3}{*}{2.447} \\
\hline & Post-burn & 7.91E-04 & 2.91E-10 & & & & \\
\hline & 1 yr Post-burn & $1.081 \mathrm{E}-03$ & $1.46 \mathrm{E}-07$ & & & & \\
\hline \multirow{3}{*}{${ }^{\mathrm{b}} \mathrm{K}_{\mathrm{fs}}(\mathrm{cm} / \mathrm{sec})$} & Pre-burn & $1.27 \mathrm{E}-04$ & $8.52 \mathrm{E}-10$ & \multirow{3}{*}{2} & \multirow{3}{*}{0.128} & \multirow{3}{*}{0.910} & \multirow{3}{*}{4.303} \\
\hline & Post-burn & $1.24 \mathrm{E}-04$ & $6.86 \mathrm{E}-10$ & & & & \\
\hline & 1 yr Post-burn & NA & NA & & & & \\
\hline \multirow{3}{*}{${ }^{\mathrm{c}} \mathrm{K}_{\mathrm{fs}}(\mathrm{cm} / \mathrm{sec})$} & Pre-burn & $4.31 \mathrm{E}-04$ & $1.02 \mathrm{E}-07$ & \multirow{3}{*}{2} & \multirow{3}{*}{0.787} & \multirow{3}{*}{0.575} & \multirow{3}{*}{12.706} \\
\hline & Post-burn & 2.35E-04 & $2.21 \mathrm{E}-08$ & & & & \\
\hline & 1 yr Post-burn & NA & NA & & & & \\
\hline \multirow{3}{*}{ Surface Area $\left(\mathrm{m}^{2} / \mathrm{g}\right)$} & Pre-burn & 9.915 & 0.003 & \multirow{3}{*}{7} & \multirow{3}{*}{3.609} & \multirow{3}{*}{0.009} & \\
\hline & Post-burn & 7.372 & 3.969 & & & & 2.365 \\
\hline & 1 yr Post-burn & 7.502 & 3.452 & & & & \\
\hline
\end{tabular}

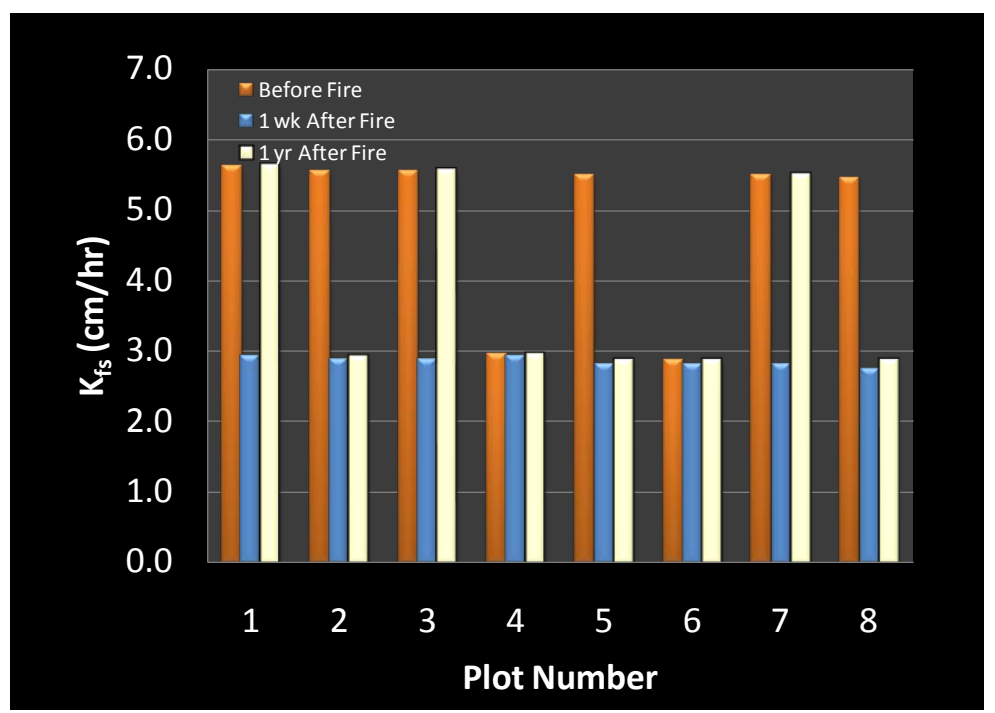

Figure 3.33. Comparison of In-Situ Pre-Burn and Post-Burn Estimates of the Hydraulic Conductivity 


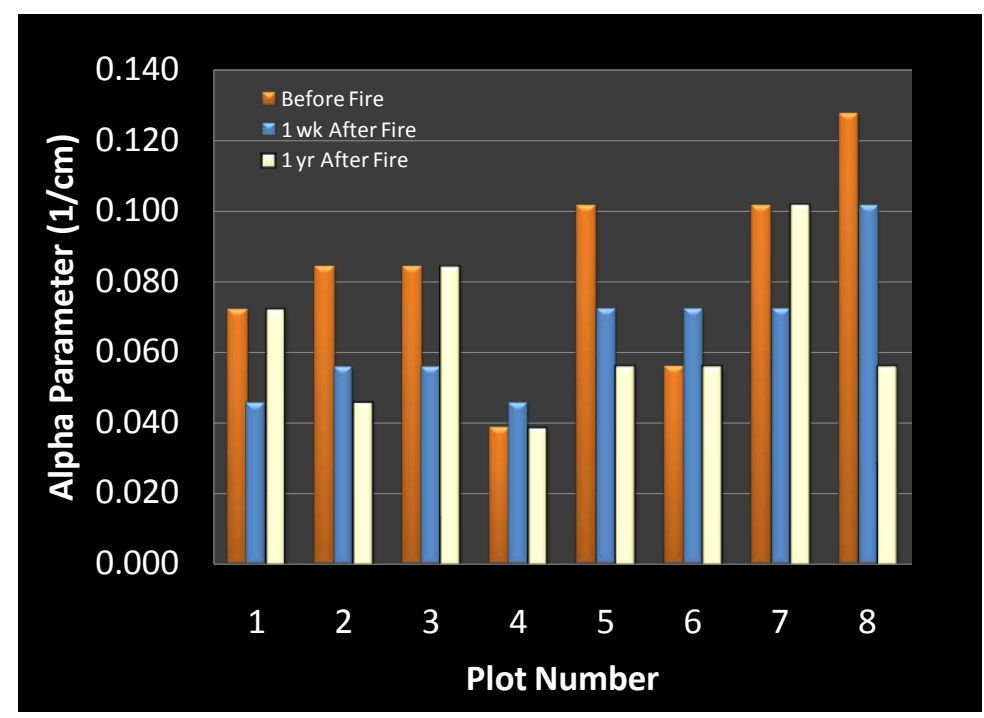

Figure 3.34. Comparison of In Situ Pre-Burn and Post-Burn Estimates of the Alpha Parameter

\subsection{Fire Effects on Soil Water Storage}

Water balance is the most comprehensive approach for assessing the field-scale hydrologic performance of an engineered barrier. Thus, observing differences in the water-balance components between the burned and unburned sections should provide insight into the effects of the fire. The most immediate effect was an increase in surface runoff with the first event in almost 15 years occurring in January 2009. A comparison of the soil water profiles measured on the burned (north) and unburned (south) sections over the last year also show significant differences that can be directly attributed to the fire. These differences are best interpreted in terms of soil water storage, $\mathrm{W}$.

In September 2008, just before the fire, the soil water storage was mostly depleted, and the north and south sides showed no differences in water-content distributions (Figure 3.35). By January 2009, after a relatively wet winter, a difference in the water-content profiles could be seen between the north and south sections with the south section being considerably wetter in the top $0.7 \mathrm{~m}$ and with the north section showing slightly wetter conditions at depth $(0.8$ to $1.6 \mathrm{~m})$. With both sides receiving the same amount of precipitation, the difference in water-content distribution is due to changes induced by the fire, although the discrepancy is somewhat counter intuitive. The lower near-surface water content can be attributed to increased evaporation from the bare surface whereas the developing moisture front at depth is due to redistribution of water that moved beyond the evaporative depth. The wetting front developing at depth is more obvious in the March 2009 profile. After the start of spring, the depletion in moisture content (owing to plant uptake) increased, and there was a sharp reduction of moisture in the 0 to $0.8 \mathrm{~m}$ depth on the south side, whereas the water content at depth continued to increase. The rapid decrease in the top 0.8 $\mathrm{m}$ is likely due to uptake by evergreen $A$. tridentata and sparse shallow rooted active bunchgrasses. By June, the profiles had reversed with the burned north section being considerably wetter than the south unburned section with the leading edge of the wetting front persisting at depth. By July, the difference between the burned and unburned sections was much smaller, although the burned section was still wetter. Perhaps the most striking observation is that despite the removal of plants from the north section, the soil water content was depleted to an amount almost identical to the unburned section. Owing to the 


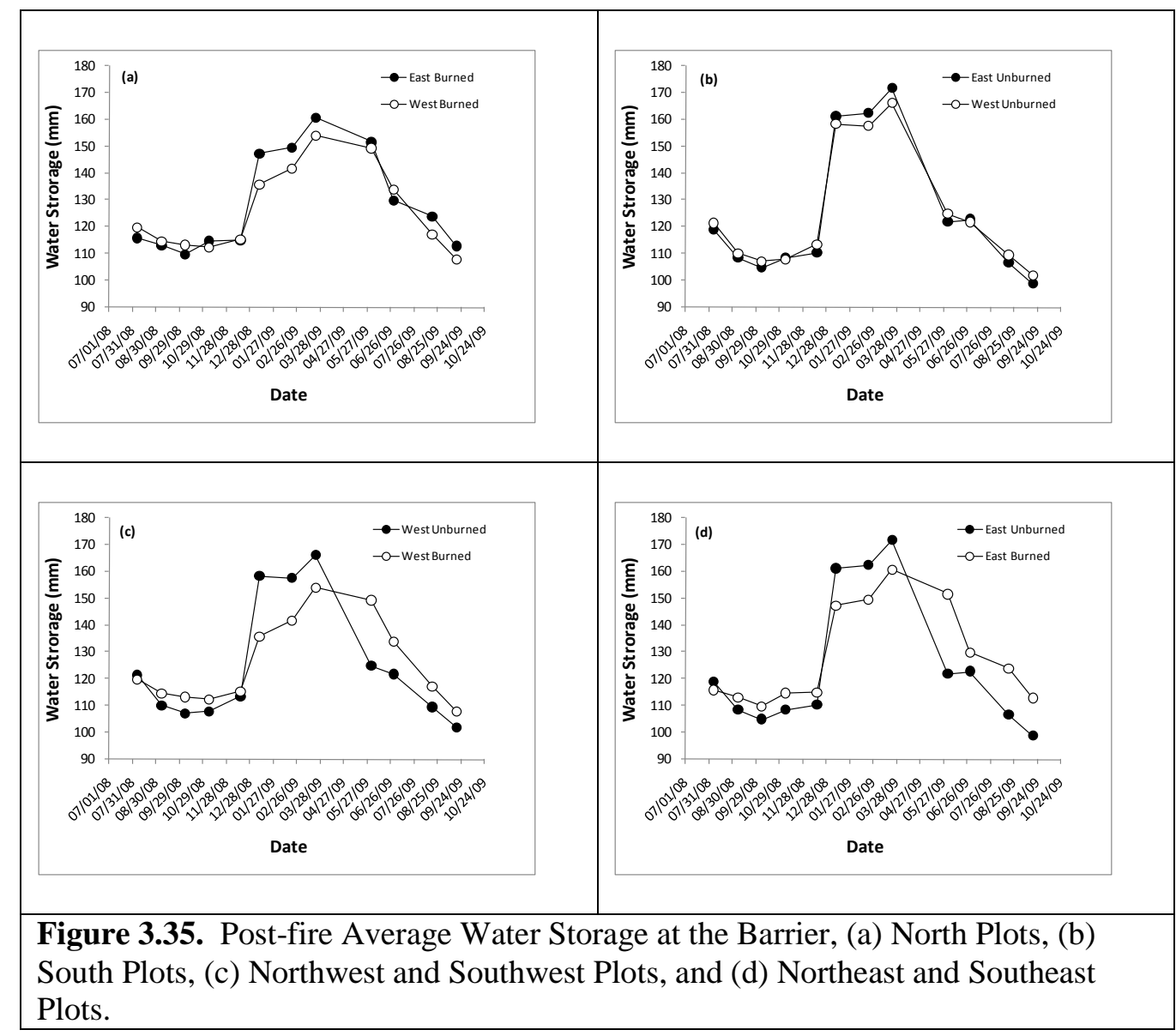

relatively low ground cover on the recovering burnt section and the relatively small plants, it is unlikely that this much water was removed by transpiration. Thus, evaporation may have been the dominant mechanism. If due entirely to evaporation, the evaporative depth appears to extend much deeper than the top few centimeters that is typically assumed in uncoupled models for predicting water-balance processes. An alternative explanation is higher than expected transpiration on the burned area. While there was relatively little leaf area in the burned area compared with the unburned area, it is possible that root zones were larger and that transpiration rates are relatively high given the strong vapor potential gradient. This would result in a much higher draw-down than on a truly bare soil. Fayer and Gee (2006) concluded that evaporation alone can be an effective mechanism for reducing water storage in silt loam soils based on measurements made at Field Lysimeter Test Facility (FLTF).

\subsection{Fire Effects on Soil Nutrient Status}

A major issue in assessing the effect of fire on barrier performance is the possibility of change to the soil chemical system that could result in a loss of soil nutrients, particularly nitrogen. To assess the effects of fire on the soil chemical system, a number of geochemical properties were measured pre- and post-burn. The results derived from samples collected immediately after the burn are summarized in Table 3.20. Results from samples collected one year after the burn are summarized in Table 3.21. 
Table 3.20. Effect of Fire on Immediate Post-Burn Soil Nutrient Status (data provided by Northwest Agricultural Consultants, NWAg, Kennewick, Washington)

\begin{tabular}{|c|c|c|c|c|c|c|}
\hline Variable & Sampling & Mean & Variance & $\mathrm{t}_{\text {stat }}$ & $\begin{array}{c}\mathrm{P}(\mathrm{T} \leq \mathrm{t}) \\
\text { Two-Tail }\end{array}$ & $\begin{array}{c}\mathrm{t}_{\text {crit }} \\
\text { Two-Tail } \\
\end{array}$ \\
\hline \multirow{2}{*}{ Organic Matter (\%) } & Pre-burn & 0.916 & 0.053 & \multirow{2}{*}{-5.449} & \multirow{2}{*}{ 4.11E-06 } & \multirow{2}{*}{2.03} \\
\hline & Post-burn & 1.256 & 0.105 & & & \\
\hline \multirow{2}{*}{$\mathrm{pH}$} & Pre-burn & 8.036 & 0.046 & \multirow{2}{*}{-12.520} & \multirow{2}{*}{$1.74 \mathrm{E}-14$} & \multirow{2}{*}{2.03} \\
\hline & Post-burn & 8.978 & 0.147 & & & \\
\hline \multirow{2}{*}{ CEC (meq/100 g) } & Pre-burn & 10.323 & 0.0023 & \multirow{2}{*}{-0.3979} & \multirow{2}{*}{0.7025} & \multirow{2}{*}{2.36} \\
\hline & Post-burn & 10.4 & 0.291 & & & \\
\hline \multirow{2}{*}{$\begin{array}{l}\text { Electrical Conductivity } \\
(\mathrm{mmho} / \mathrm{cm})\end{array}$} & Pre-burn & 0.189 & 0.001 & \multirow{2}{*}{-15.905} & \multirow{2}{*}{$1.37 \mathrm{E}-17$} & \multirow{2}{*}{2.03} \\
\hline & Post-burn & 0.493 & 0.012 & & & \\
\hline \multirow{2}{*}{ Ammonium-N (mg/kg) } & Pre-burn & 4.050 & 9.693 & \multirow{2}{*}{-12.477} & \multirow{2}{*}{ 1.93E-14 } & \multirow{2}{*}{2.03} \\
\hline & Post-burn & 15.511 & 20.559 & & & \\
\hline \multirow{2}{*}{ Nitrate-N (mg/kg) } & Pre-burn & 3.622 & 3.461 & \multirow{2}{*}{-3.464} & \multirow{2}{*}{0.001422} & \multirow{2}{*}{2.03} \\
\hline & Post-burn & 5.206 & 2.821 & & & \\
\hline \multirow{2}{*}{ P-Bicarbonate (meq/100 g) } & Pre-burn & 11.389 & 17.787 & \multirow{2}{*}{-9.844} & \multirow{2}{*}{$1.28 \mathrm{E}-11$} & \multirow{2}{*}{2.03} \\
\hline & Post-burn & 26.028 & 49.056 & & & \\
\hline \multirow{2}{*}{ K-Bicarbonate (meq/100g) } & Pre-burn & 239.750 & 4276.250 & \multirow{2}{*}{-7.589} & \multirow{2}{*}{ 6.75E-09 } & \multirow{2}{*}{2.03} \\
\hline & Post-burn & 380.472 & 12136.599 & & & \\
\hline \multirow{2}{*}{ Calcium } & Pre-burn & 17.508 & 0.646 & \multirow{2}{*}{-0.935} & 0356426 & 203 \\
\hline & Post-burn & 17.692 & 0.645 & & $0.3564<0$ & 2.03 \\
\hline Magnesium & Pre-burn & 1.409 & 0.027 & -2479 & 0018127 & 203 \\
\hline IVIdgnestum & Post-burn & 2.686 & 9.328. & $-2.4 / 9$ & 0.018127 & 2.03 \\
\hline Sodium & Pre-burn & 0.054 & 0.001 & -1953 & (058824 & 203 \\
\hline soalum & Post-burn & 0.095 & 0.015 & -1.953 & 0.058824 & 2.03 \\
\hline
\end{tabular}

Soil $\mathrm{pH}$ is a measure of the relative acidity of the soil solution in equilibrium with the solid particles and is important in assessing the relative availability of soil nutrients. The mean $\mathrm{pH}$ values for samples collected before the burn was $8.036 \pm 0.21$ compared to $8.978 \pm 0.38$ after the burn. The increases in $\mathrm{pH}$ can be attributed to ash accretion (Ahlgren and Ahlgren 1960, Smith 1970). Soil pH increases because mineral substances are released as oxides or carbonates that usually have an alkaline reaction (e.g., Youngberg 1953, Daubenmire 1968). Soil pH is known to control the availability of most nutrients, and this is important in nutrient-limiting environments like engineered ecosystems where fertilizer is typically not applied. An increase in $\mathrm{pH}$ typically increases the cycling of various elements critical for plant growth. Soil $\mathrm{pH}$ does not directly control $\mathrm{N}$ availability, but does affect soil microbial activity. Acidic soil conditions can limit microbial activity and slow down mineralization of $\mathrm{N}$ (from organic matter) as well as nitrification. High soil $\mathrm{pH}$ can result in significant loss of $\mathrm{N}$ by volatilization. The availability of phosphorus is strongly influenced by soil $\mathrm{pH}$, reaching a maximum between $\mathrm{pH}$ values of 5.5 and 7.5. Acidic soil conditions $(\mathrm{pH}<5.5)$ result in dissolution of aluminum and iron minerals, causing a precipitation of phosphorus, which renders it unavailable. Basic soil conditions $(\mathrm{pH}>7.5)$ result in an excess of calcium in the soil solution, which can also precipitate with phosphorus rendering it unavailable. 
Table 3.21. Effect of Fire on Post-Burn Soil Nutrient Status 1 Year after Burn Status (data provided by Northwest Agricultural Consultants (NWAg), Kennewick, Washington)

\begin{tabular}{|c|c|c|c|c|c|c|}
\hline Variable & Sampling & Mean & Variance & $\mathrm{t}_{\text {stat }}$ & $\begin{array}{c}\mathrm{P}(\mathrm{T} \leq \mathrm{t}) \\
\text { Two-Tail }\end{array}$ & $\begin{array}{c}\mathrm{t}_{\text {crit }} \\
\text { Two-Tail }\end{array}$ \\
\hline \multirow[b]{2}{*}{ Organic Matter (\%) } & Pre-burn & 0.916 & 0.053 & \multirow{2}{*}{-5.622} & \multirow{2}{*}{ 2.43E-06 } & \multirow{2}{*}{2.03} \\
\hline & Post-burn & 1.374 & 0.221 & & & \\
\hline \multirow[b]{2}{*}{$\underline{\mathrm{p}} \mathrm{H}$} & Pre-burn & 8.036 & 0.046 & \multirow{2}{*}{12.925} & \multirow{2}{*}{ 6.94E-15 } & \multirow{2}{*}{2.03} \\
\hline & Post-burn & 7.572 & 0.021 & & & \\
\hline \multirow[b]{2}{*}{ CEC (meq/100 g) } & Pre-burn & 10.323 & 0.002 & \multirow{2}{*}{1.692} & \multirow{2}{*}{$1.29 \mathrm{E}-01$} & \multirow{2}{*}{2.31} \\
\hline & Post-burn & 9.761 & 0.387 & & & \\
\hline \multirow{2}{*}{$\begin{array}{l}\text { Electrical Conductivity } \\
\text { (mmho/cm) }\end{array}$} & Pre-burn & 0.189 & 0.001 & \multirow{2}{*}{-6.177} & \multirow{2}{*}{$4.52 \mathrm{E}-07$} & \multirow{2}{*}{2.03} \\
\hline & Post-burn & 0.261 & 0.005 & & & \\
\hline \multirow{3}{*}{ Ammonium-N (mg/kg) } & Pre-burn & 4.050 & 9.693 & \multirow{2}{*}{-7.358} & \multirow{2}{*}{$1.32 \mathrm{E}-08$} & \multirow{2}{*}{2.03} \\
\hline & Post-burn & 10.472 & 24.393 & & & \\
\hline & Pre-burn & 3.622 & 3.461 & \multirow{2}{*}{-9.355} & \multirow{2}{*}{ 4.71E-11 } & \multirow{2}{*}{2.03} \\
\hline \multirow[t]{2}{*}{ Nitrate-N (mg/kg) } & Post-burn & 16.719 & 71.939 & & & \\
\hline & Pre-burn & 11.389 & 17.787 & \multirow{2}{*}{-11.747} & \multirow{2}{*}{$1.07 \mathrm{E}-13$} & \multirow{2}{*}{2.03} \\
\hline \multirow[t]{2}{*}{ P-Bicarbonate (meq/100 g) } & Post-burn & 32.528 & 108.542 & & & \\
\hline & Pre-burn & 239.750 & 4276.250 & \multirow{2}{*}{-6.858} & \multirow{2}{*}{ 5.83E-08 } & \multirow{2}{*}{2.03} \\
\hline \multirow[t]{2}{*}{ K-Bicarbonate (meg/100g) } & Post-burn & 326.611 & 8974.587 & & & \\
\hline & Pre-burn & 17.508 & 0.646 & \multirow{2}{*}{7.448} & סחתבח 1 & ר \\
\hline \multirow[t]{2}{*}{ Calcium } & Post-burn & 16.253 & 0.787 & & $1.0 \angle 5-00$ & 2.05 \\
\hline & Pre-burn & 1.409 & 0.027 & -6275 & 07 & 202 \\
\hline Magnesium & Post-burn & 1.672 & 0.037 & -0.275 & $0.00 \mathrm{~L}-0 /$ & 2.00 \\
\hline & Pre-burn & 0.054 & 0.001 & -4620 & 503505 & 702 \\
\hline Sodium & Post-burn & 0.081 & 0.001 & $-4.0<0$ & $3.055-60$ & 2.00 \\
\hline
\end{tabular}

Potassium is soluble at any $\mathrm{pH}$, but as the $\mathrm{pH}$ decreases, the total potassium declines whereas an increase in $\mathrm{pH}$ may force potassium into non-exchangeable positions and suppress availability. The availability of magnesium is also sensitive to $\mathrm{pH}$. The availability of $\mathrm{Mg}$ decreases with decreasing $\mathrm{pH}$ because of increased competition with excess hydrogen, aluminum, and iron for cation exchange sites. As the $\mathrm{pH}$ decreases, the availability of micronutrients like iron, manganese, zinc, boron, and copper all increase. However, samples were not analyzed for micronutrients. The increase in $\mathrm{pH}$ following the burn could therefore directly impact the availability of $\mathrm{P}$ and $\mathrm{K}$ as well as indirectly impact the availability of N. The dominant species, A. tridentata, prefers $\mathrm{pH}$ in the range of 6 to 8.2.

Electrical conductivity of the soil is a measure of the amount of soluble salts present and hence the salinity. Table 3.20 shows that the electrical conductivity of the $1: 1$ soil extract, $\mathrm{EC}_{1: 1}$, after the fire. The value of $\mathrm{EC}_{1: 1}$ after the fire was $0.493 \mathrm{mmho} / \mathrm{cm}(0.493 \mathrm{dS} / \mathrm{m})$, which was significantly higher than the pre-fire value of $0.189 \mathrm{mmho} / \mathrm{cm}(0.189 \mathrm{dS} / \mathrm{m})$. The tendency of fire to volatilize nutrients, increase soil concentrations of mineral elements, and reduce available moisture is consistent with an increase in electrical conductivity. In fact, soil elemental analyses indicate that concentrations of major nutrients 
increased following the fire. While this could potentially result in a short-term increase in nutrient availability, it also results in an increase in salinity, which could have detrimental effects. $\mathrm{EC}_{1: 1}$ alone, however, is insufficient to assess the effects of salinity on plant growth because the salt concentration at the root surface can be much greater than in the bulk soil. The saturated paste value, ECe, is a better measure and can be estimated from $\mathrm{EC}_{1: 1}$ as $\mathrm{EC}_{\mathrm{e}}=2.2 \mathrm{EC}_{1: 1}$. The estimated $\mathrm{EC}_{\mathrm{e}}$ before the fire was $0.416 \mathrm{dS} / \mathrm{m}$. The estimated $\mathrm{EC}_{\mathrm{e}}$ after the fire was $1.085 \mathrm{dS} / \mathrm{m}$. Soils with $\mathrm{EC}_{\mathrm{e}}$ values in the range 0 to $2 \mathrm{dS} / \mathrm{m}$ are considered nonsaline and are not expected to have any effect on plant growth. The USDA National Plant Database lists the salt tolerance for A. tridentata as "low," although Swift (1997) suggests that the plant will tolerate highly saline soils (up to $6 \mathrm{dS} / \mathrm{m}$ ). Soil CEC measured on pre- and post-burn samples did not show any significant difference.

The responses of individual nutrients to fire are different. Furthermore, each nutrient has an inherent temperature threshold where volatilization occurs (DeBano 2001, Raison et al. 1985). These thresholds can be divided into three general nutrient categories: sensitive, moderately sensitive, and relatively insensitive. Nitrogen (Hosking 1938) and S (Tiedemann 1987) are considered sensitive because they have thresholds as low as 200 to $375^{\circ} \mathrm{C}$, respectively. Potassium (K) and P are moderately sensitive, having threshold temperatures of $774^{\circ} \mathrm{C}$ (Raison et al. 1985). Magnesium (Mg), Calcium (Ca), and Manganese (Mn) are relatively insensitive, with high threshold temperatures of $1,107^{\circ} \mathrm{C}, 1,484^{\circ} \mathrm{C}$, and $1,962^{\circ} \mathrm{C}$, respectively. Because the threshold temperatures of $\mathrm{N}, \mathrm{P}$, and $\mathrm{K}$ are lower than the flaming temperatures of woody fuels $\left(1,100^{\circ} \mathrm{C}\right)$ and, except for $\mathrm{P}$, lower than glowing combustion temperatures $\left(650^{\circ} \mathrm{C}\right)$, these nutrients are readily volatilized from soil organic matter during combustion. Thus, significant changes in the soil concentration of $\mathrm{N}, \mathrm{P}$, and $\mathrm{K}$ can be expected.

The effects of fire on nitrogen $(\mathrm{N})$ in engineered ecosystems are not well understood. Thus, this study also investigated the effect of fire on $\mathrm{N}$ in the amount of $\mathrm{NO}_{3}-\mathrm{N}$ and $\mathrm{NH}_{4}-\mathrm{N}$ in barrier soils. A comparison of $\mathrm{N}$ in the fire treatments against those in the control showed a significant increase in $\mathrm{NO}_{3}-\mathrm{N}$ after the fire. Post-burn samples contained a mean $\mathrm{NO}_{3}-\mathrm{N}$ concentration of $5.206 \mathrm{mg} / \mathrm{kg}$ compared to $3.622 \mathrm{mg} / \mathrm{kg}$ before the burn, a $44 \%$ increase. The content of $\mathrm{NH}_{4}-\mathrm{N}$ increased from $4.050 \mathrm{mg} / \mathrm{kg}$ to $15.511 \mathrm{mg} / \mathrm{kg}$, a $282 \%$ increase. On a plot-by-plot basis, the responses of $\mathrm{N}$ to fire varied with different fuel load and soil temperature. Concentrations of $\mathrm{NH}_{4}-\mathrm{N}$ can increase, decrease, or remain unchanged, depending on fire severity and duration. Increases in $\mathrm{NH}_{4}-\mathrm{N}$ immediately following a fire appear to be related to the soil temperature reached. DeBano (1991) suggested that most of the soil $\mathrm{N}$ is volatilized by high-severity fires, particularly on or near the surface with only small amounts being transferred downward through the soil. Conversely, large amounts of $\mathrm{NH}_{4}-\mathrm{N}$ is typically found in ash and underlying soil after low-severity fires (DeBano 1991).

Heat intensifies the physiochemical processes, which leads to the decomposition of nitrogencontaining organic matter and the release of ammonia from soil minerals (Arefyeva and Kolesnikov 1964). Ammonia loss peaks at 250 to $300^{\circ} \mathrm{C}$, which explains why $\mathrm{NH}_{4}-\mathrm{N}$ increases while organic $\mathrm{N}$ decreases as a result of volatilization at $200^{\circ} \mathrm{C}$ (Raison 1979). Nonetheless, increases in the soil $\mathrm{NH}_{4}{ }^{+}$ pool is only temporary with a gradual decrease to pre-fire levels after about 1 year (Wan et al. 2001). Comparatively small increases (24\%) have been reported in the soil $\mathrm{NO}_{3}-\mathrm{N}$ pool immediately after a fire with a continued increase over time reaching a maximum of approximately three times the pre-fire level within 0.5 to 1 years after fire, followed by a decline (Wan et al. 2001). Studies of prescribed fires show an increase in nitrogen for 2 or 3 months following the fire (USGS 2002). Cheatgrass is favored in highnitrogen conditions over native plants, which can tolerate lower levels of nitrogen. Prescribed fires are typically scheduled in the fall and would therefore increase the seed production of annual grasses such as 
cheatgrass. Wildfires may have had a similar effect, but typically occurred in late summer or early fall. Therefore, a possible tool in the management of disturbed engineered ecosystems may be to use fire in the spring before cheatgrass sets seed.

Table 3.20 also compares the mean soil concentration of phosphorous (P). The mean pre-burn $\mathrm{P}$ concentration was $11.389 \mathrm{meq} / 100 \mathrm{~g}$ compared to a post-burn value of $26.03 \mathrm{meq} / 100 \mathrm{~g}$. This represents a $124 \%$ increase in P. Phosphorus is known to respond differently to elevated temperatures than N. As much as $60 \%$ of the total $\mathrm{P}$ is typically lost by non-particulate transfer when organic matter is totally combusted (Raison et al. 1985). As a result, relatively large amounts of highly available P can be found in the ash and on the soil surface immediately following fire. However, this $\mathrm{P}$ can be quickly immobilized in insoluble compounds especially if soil is rich in calcium.

While there have been numerous reports on the effects of fire on the availability of $\mathrm{N}$ and $\mathrm{P}$, comparatively few studies discuss other nutrients like potassium (K), calcium (Ca), sodium (Na), and magnesium (Mg). Table 3.20 shows that $\mathrm{K}$ increased by 58.6\% after the fire whereas $\mathrm{Mg}$ increased by 91\%. In contrast, Ca and Na remained statistically unchanged. These results are consistent with published reports. A number of reports suggest that all of these cations may increase after fire (Christensen 1976; Raison 1979). Increases in soluble $\mathrm{K}$ in the litter and A horizon, or topsoil, have been reported when temperatures remain below $200^{\circ} \mathrm{C}$ (White et al. 1973). Calcium, iron (Fe), and manganese (Mn) have been reported to decrease (Ohr and Bragg 1985). However, Ohr and Bragg also found that if the plot burned in consecutive years, then $\mathrm{K}$, copper $(\mathrm{Cu}), \mathrm{Fe}$, and zinc $(\mathrm{Zn})$ availability increased.

The soil test for organic matter is an indication of soil productivity, and from the percent of organic matter, the estimated nitrogen release to the crop can be calculated. The amount of available nitrogen released to the plant is about 28 to $56 \mathrm{~kg}$ of actual nitrogen per hectare per year for each percent of organic matter. The actual amount released will depend upon a number of factors, including soil water content, temperature, and length of growing season. The pre-burn organic matter content is therefore equivalent to 26 to $51 \mathrm{~kg}$ of nitrogen per hectare per year. The post-burn organic matter content is equivalent to 35 to $70 \mathrm{~kg}$ of nitrogen per hectare per year. The mean post-burn organic-matter content showed a significant increase (37\%) from conditions before the fire based on the Walkley-Black method (Table 3.20). This result is somewhat counter intuitive as heating the soil to temperatures between 220 and $460^{\circ} \mathrm{C}$ is known to combust soil organic matter. Organic matter determined by loss on ignition showed an 8\% decrease. Published reports suggest that high temperatures generated by wildfire can remove virtually all near-surface soil organic matter, thereby altering the cation exchange capacity of the soils. These types of changes have been observed as deep as $80 \mathrm{~mm}$. There is no physical explanation of the apparent increase by the Walkley-Black method. Thus, it may be due to the precision of the method. The method detection limit is approximately $0.10 \%$ with a reproducibility of $\pm 8 \%$. 


\subsection{Summary and Conclusions}

A critical unknown in long-term engineered surface barrier use for waste site remediation is the postfire hydrologic function where institutional controls are intact, but there are no resources to implement maintenance activities, such as re-planting of vegetation. A study was recently conducted at the Hanford Site to gain insight into the effects of wildfire on the function of an engineered barrier. This report documents the test and the short-term effects based on data collected between September 2008, and September 2009, one year after the controlled burn.

A controlled burn was used to simulate a wildfire on the north half of the barrier's surface in September 2008. Before the fire, the surface was characterized to establish initial soil physical and hydraulic properties, plant community structure, nature of the seed bank, and animal use. The surface was divided into nine $12 \times 12 \mathrm{~m}$ plots; each was randomly assigned one of the fuel loads ranging from 4.7 to 5.71 tons/acre and ignited at the perimeter. Unburned biomass was manually burned off with a drip torch. The progress of the fire was monitored using automated measurements of temperature, visual observation of flame height, and by digital video. Immediately after the fire, near-surface soil samples were collected to quantify changes in soil physical properties, including particle-size distribution, porosity, bulk density, mineralogy, water repellency, and hydraulic conductivities. The gravel content was also determined to identify the inflationary or deflationary responses to fire and to reveal the ability of the surface to resist post-fire erosive stresses. Non-destructive measurements of near-surface moisture content and bulk density were made using a nuclear density gauge. Samples were also analyzed to quantify soil nutrient status, including changes in soil $\mathrm{pH}$, cation exchange capacity, specific surface area, and the concentration of macro nutrients (e.g., N, P, and K), and micro nutrients, such as Na, Mg, and Ca, that may play a role in the post-fire recovery of vegetation. General assessments of shrub survival were made with periodic assessments of recovery and recruitment occurring over time.

Additional fuel was imported onto the barrier surface to create different fuel loads. The controlled burn took about 7 minutes to consume the entire north half of the barrier. Flame heights exceeded $9 \mathrm{~m}$ (30 ft), and temperatures ranged from $250^{\circ} \mathrm{C}\left(482^{\circ} \mathrm{F}\right)$ at $1.5 \mathrm{~cm}\left(0.6 \mathrm{in}\right.$.) below the surface to over $700^{\circ} \mathrm{C}$ $\left(1292^{\circ} \mathrm{F}\right)$ at $1 \mathrm{~m}(3.3 \mathrm{ft})$ above the surface. Relative fire intensity was the greatest on the northwest side of the surface while the lowest values were found along the northeast corner and southeast corners. This observation is consistent with the distribution of fuel and confirms the patterns inferred from measurements of air and soil temperature. Soil inflation and deflation exhibited significant changes that also appear to be correlated with fire intensity. It appears that deflation was highest where fire intensity was the greatest. Continued monitoring of the erosion pins may reveal substantial movement of soils around the surface until the plant community re-establishes itself.

Species composition on the burned surface changed markedly from prior years and relative to the unburned half of the barrier surface at the two analog sites. The observed increase in the proportion of annuals and biennials in the population is characteristic of burned surfaces that have become dominated by ruderal species. It is likely that native perennial species will come to dominate the burned area again as $A$. tridentata and E. nauseosa have started to re-establish, although at low numbers. The time it will take for species richness to drop to previous levels needs to be monitored to see if it does return to pre-fire conditions. Based on observations at the McGee Ranch old burn analog site, it can be predicted that $A$. tridentata will produce lots of seed as long as competition remains low, and there is access to stored water to support the high seed production. 
Greenhouse seedling emergence tests were conducted to assess the seed bank of pre- and post-burn soils and of two analog sites at the McGee Ranch. Results show no difference in the number of species emerging from the seed bank collected before and after the fire. There were fewer species emerging from the seed bank on the side slopes and more species emerging from the two McGee Ranch analog sites. The most striking observation is the emergence of $A$. tridentata from the seed bank after the fire, which suggests that this dominant shrub will return after fire. The lack of $P$. secunda in the seed bank and very low cover on the barrier surface makes the plant community unlike that of the two McGee Ranch sites and not likely to return to a community like those at McGee Ranch. If such a community is considered the natural condition then this species should be actively restored. This could be done by applying seed to the surface in the coming fall. Some seed will likely successfully germinate without disturbing the soil surface.

Leaf area index measurements confirmed the substantial differences in plant communities after fire. These values are useful because they allow for the prediction of plant growth and thus water extraction rates from the surface. Xylem pressure potential data also support model development and provide a means of assessing soil water potential at high density across the surface. The relatively high xylem pressure potential on the burned half of the barrier in September suggests that not all the water in the soil profile will be removed before the fall rains begin. This observation is in contrast to conditions that existed in the first season after planting in 1994. At that time planted grasses and shrubs were small and the size and cover of $S$. kali was extremely high. The cover of $S$. kali successfully extracted all stored water even though the surface had been irrigated. It would be useful to track xylem water potential through the fall to see if the plants are able to dry the surface out before the fall rains begin. Greater soil respiration rates under dry surface conditions in the burned area compared with the unburned area observations support the supposition that plants experiencing wetter soil profiles will show more active root respiration. Continued soil respiration observations may be a good surrogate of root activity as the vegetation recovers.

Soil organic matter, soil wettability, and hydraulic conductivity all decreased significantly relative to pre-fire conditions. Dry bulk density increased and porosity decreased relative to pre-fire conditions. Laboratory analysis of post-fire soil samples showed an increase in major soil nutrients, $\mathrm{pH}$, and electrical conductivity measured in 1:1 extracts but a decrease in organic matter. Changes in mineralogy were also observed that could be attributed to the fire. Observed decreases in wettabilty and organic matter are indicative of conditions conducive to surface water, runoff, and soil loss. In fact, one runoff event was recorded in January 2009, the first in 15 yrs of monitoring, although the amount was a fraction of a mm. Hydrophobicity decreased as water content of the surface increased with very few locations showing evidence of reduced wettabilty in January 2009. After 1 year, hydrophobicity has returned to pre-burn levels with only $16 \%$ of samples still showing signs of decreased wettability. Although there were significant changes in hydraulic conductivity immediately after the fire, hydraulic conductivity measured by tension infiltrometer 1 year after the fire shows no significant difference from pre-burn values.

There were significant differences in the rate of accumulation and loss of soil moisture on the burned and unburned sections. On the burned section, water storage was higher during the fall, increased more slowly with the onset of winter precipitation owing to higher evaporation, and decreased more slowly in the spring owing to lower evapotranspiration. The result was significantly higher water storage on the burned section at the end October 2009, which translates into a lower storage capacity prior to the onset of winter precipitation. Nonetheless, barrier effectiveness has not been compromised as the storage capacity is some $600 \mathrm{~mm}$. 
The barrier surface shows continued use by animals. The fire apparently reduced animal burrowing. The holes can potentially be a source of variation in soil water patterns, but they are small and make up a very small portion of the surface. There is little or no use of the surface by large burrowing animals, such as badgers, yet. The use of $E$. wawawaiensis by rabbits is substantial. Herbivory was significant and potentially can lead to a reduction in E. wawawaiensis, especially if seed production is reduced. There were seeds of $E$. wawawaiensis in the seed bank, but it is not known if their number would be greater without herbivory. Insect galls on A. tridentata were significant and damaged shrubs with heavy infestation. This infestation likely will continue to reduce $A$. tridentata populations. Further work documenting belowground effects by insects and mammals would provide useful information on channel development and other soil pedogenesis processes.

At the conclusion of this study, it is anticipated that uncertainty in long-term projections of barrier will decrease. A reduction in uncertainty about long-term performance is needed to increase acceptance of barrier technology and to demonstrate future barrier performance. Lessons-learned for long-term monitoring instrumentation, including the type, protection, and placement of instrumentation, will enhance monitoring reliability and concurrently reduce overall life-cycle costs. The combination of barrier-design modifications and barrier-performance monitoring should lead to reductions in barrier maintenance costs. 


\subsection{References}

Ahlgren IF and CE Ahlgren. 1960. "Ecological effects of forest fires.” Bot. Rev. 26:483-533.

Arefyeva, Z.N., and B.P. Kolesnikov. 1964. "Dynamics of ammonia and nitrate nitrogen in forest soils of the Transurals at high and low temperatures.” Soviet Soil Science 3:246-260.

ASTM-American Society of Testing and Materials. 2000. Standard Practice for Classification of Soils for Engineering Purposes (Unified Soil Classification System). ASTM D2487-00. Philadelphia, Pennsylvania.

Borman, Michael M and David A. Pyke. 1994. "Successional theory and the desired plant community approach.” Rangelands 16(2): 82-84.

Boudell J, SO Link, and JR Johanssen. 2002. “Effect of soil microtopography on seed bank distribution in the shrub-steppe.” Western North American Naturalist 62:14-24.

Brunauer S, PH Emmett, and E Teller. 1938. “Adsorption of Gases in Multimolecular Layers.” Journal of the American Chemical Society 60:309-319.

Christensen, N.L. 1976. "Short-term effects of mowing and burning on soil nutrients in Big Meadows, Shenandoah National Park.” Journal of Range Management 29:508-509.

Daniel, D.E. 1994. Surface barriers: Problems, solutions and future needs. p. 441-487. In Proc. of the 33rd Hanford Symp. on Health and the Environ., Richland, WA. 7-11 Nov. 1994. Battelle Press, Columbus, $\mathrm{OH}$.

Daubenmire R. 1959. “A Canopy-Coverage Method of Vegetational Analysis.” Northwest Science 33:43-64.

Daubenmire R. 1968. “Ecology of fire in grasslands.” In: Advances in ecological research, Vol 5, JB Cragg (ed), pp. 209-266, Academic Press, New York.

DeBano LF. 1981. Water Repellent Soils: A State of the Art, General Technical Report. PSW-46, Pacific Southwest Forest and Range Exp. Sta., U.S. Department of Agriculture Forest Service, Berkeley, California.

DeBano, L.F. 2000. "Water repellency in soils: a historical overview.” Journal of Hydrology 231/232: 4-32.

DeMarco A, AE Gentile, C Arena, and DeS AV Virzo. 2005. “Organic Matter, Nutrient Content and Biological Activity in Burned and Unburned Soils of a Mediterranean Maquis Area of Southern Italy.” International Journal of Wildland Fire 14:365-377.

Dekker LW. 1998. "Effect of Drying Temperature on the Severity of Soil Water Repellency.” Soil Science 163:780-796. 
Dekker LW and CJ Ritsema. 1994. "How Water Moves in a Water-Repellent Sandy Soil: I. Potential and Actual Water Repellency.” Water Resources Research 30:2507-2517.

DOE-RL-U.S. Department of Energy-Richland Operations office. 1999. Prototype Barrier Treatability Test Report. DOE/RL-99-11, Rev. 0, DOE/RL, Richland, Washington.

Doerr SH and A Cerdà. 2005. "Fire Effects on Soil System Functioning: New Insights and Future Challenges.” International Journal of Wildland Fire 14(4) 339-342.

Dyrness, C.T. 1976. "Effect of wildfire on soil wettability in the high Cascades of Oregon.” USDA Forest Service Res. Pap. PNW-202, USDA Forest Service, Corvallis, OR.

Dwyer, S. F., B. R. Reavis, and G. Newman. 2000. Alternative landfill cover demonstration, FY2000 annual data report, SAND2000-2427, Sandia National Laboratories, Albuquerque, New Mexico.

EPA. 1989. Environmental Protection Agency, Technical Guidance for RCRMCERCLA Final Covers, United States Environmental Protection Agency, Office of Emergency and Remedial Response, Washington DC.

Fayer MJ and GW. Gee. 2006. "Multiple-Year Water Balance of Soil Covers in a Semiarid Setting.” Journal of Environmental Quality 35:366-377.

FEIS-Fire Effects Information Service. Fire Effects Information. U.S. Department of Agriculture Forest Service. Accessed September 2008 at: http://www.fs.fed.us/database/feis/plants/index.html.

Folk RL. 1980. Petrology of Sedimentary Rocks. Hemphill Publishing Company, Austin, Texas.

Friedel NH. 1991. "Range condition assessment and the concept of thresholds: a viewpoint." Journal of Range Management 44:422-426.

Gavlak, R., Horneck, D., Miller, R. O., Kotuby-Amacher, J. 2003. "Soil, Plant and Water Reference Methods for the Western Region.” WCC 103 publication WREP 125, 2nd edition, Oregon State University, Corvallis, OR.

Gee GW, AL Ward, BG Gilmore, MW Ligotke and SO Link. 1995. Hanford Prototype-Barrier Status Report: FY 1995, Pacific Northwest National Laboratory, Richland, Washington.

Gilmore BG and WH Walters. 1993. Water Erosion Field Tests for Hanford Protective Barriers: FY 1992 Status Report, PNL-8949, Pacific Northwest Laboratory, Richland, Washington.

Hosking, J. S. 1938. "The ignition at low temperatures of the organic matter in soils.” Journal of Agricultural Science 38(3):393-400.

Huffman, E.L., MacDonald, L.H., Stednick, J.D. 2001. "Strength and persistence of fire-induced soil hydrophobicity under ponderosa and lodgepole pine, Colorado Front Range.” Hydrological Processes 15:2877-2892.

Johnson EA, and K Miyanashi. 2001. “Forest fires: behavior and ecological effects.” San Diego: Academic Press 80:13-26. 
Kennedy, W. E., L. L. Cadwell, and D. H. McKenzie. 1985. "Biotic transport of radionuclides from a low-level radioactive site.” Health Phys 49:11-24.

Larsen, Isaac J., Lee H. MacDonald, Ethan Brown, Daniella Rough, Matthew J. Welsh, Joseph H. Pietraszek, Zamir Libohova, Juan de Dios Benavides-Solorio, Keelin Schaffrath. 2009. "Causes of PostFire Runoff and Erosion: Water Repellency, Cover, or Soil Sealing?” Soil Science Society of America Journal 73:1393-1407.

Laundré, J. W. 1989. "Horizontal and vertical diameter of burrows of five small mammal species in southeastern Idaho.” Great Basin Nat 49:646-649.

Laycock, W.A. 1991. "Stable states and thresholds of range condition on North American rangelands: a viewpoint.” Journal of Range Management 44:427-433.

Ligotke MW. 1994. “Control of Eolian Soil Erosion from Waste Site Surface Barriers.” In: In-Situ Remediation: Scientific Basis for Current and Future Technologies : Thirty-Third Hanford Symposium on Health and the Environment. Richland, Washington, 7-11 Nov 1994; GW Gee and NR Wing, Editors, pp. 549-559, Battelle Press, Richland, Washington.

Link SO, BD Ryan, JL Downs, LL Cadwell, J Soll, MA Hawke, and J Ponzetti. 2000. "Lichens and mosses on shrub-steppe soils in southeastern Washington.” Northwest Science 74:50-56.

Neary DG, CC Klopatek, LF DeBano, and PF Ffolliott. 1999. "Fire Effects on Belowground Sustainability: A Review and Synthesis.” Forest Ecology and Management 122:51-71.

Ohr KM and TB Bragg. 1985. "Effects of fire on nutrient and energy concentration of five prairie grass species.” Prairie Nat 17:113-126.

Pendleton DT. 1989. "Range condition as used in the soil conservation service.” In: Secondary succession and the evaluation of rangeland condition. WK Lauenroth and WA Laycock, eds., pp. 17-34, Westview Press, Inc., Boulder, CO.

Powers RF, DH Alban, RE Miller, AE Tiarks, CG Wells, PE Avers, RG Cline, RO Fitzgerald, and NS Loftus. 1990. "Sustaining Site Productivity in North American Forests: Problems and Prospects." In: Sustained Productivity of Forest Soils. SA Gessel, DS Lacate, GF Weetman, and RF Powers, Editors, pp. 49-79. Proceedings of the 7th North American Forest Soils Conference, Vancouver, British Columbia, July 1998, University of British Columbia, Vancouver, British Columbia.

Raison RJ. 1979. "Modifications of the soil environment by vegetation fires, with particular reference to nitrogen transformations: a review.” Plant and Soil 51:73-108.

Raison RJ, PK Khanna, and PV Woods. 1985. "Mechanisms of element transfer to the atmosphere during vegetation fires.” Canadian Journal of Forest Research 15:132-140.

Reynolds WD. 1993. “Unsaturated Hydraulic Conductivity: Field Measurement.” Chapter 59, pp. 633-644. In: Soil Sampling and Methods of Analysis. MR Carter, Editor, Canadian Society of Soil Science, Lewis Publishers. Boca Raton, Florida. 
Reynolds WD and DE Elrick. 1985. "In Situ Measurement of Field-Saturated Hydraulic Conductivity, Sorptivity and the $\alpha$-Parameter Using the Guelph Permeameter.” Soil Science 140(4):292-302.

Reynolds WD and DE Elrick. 1985. "In Situ Measurement of Field-Saturated Hydraulic Conductivity, Sorptivity and the $\alpha$-Parameter Using the Guelph Permeameter.” Soil Science 140(4):292-302.

Roberts, H.A. 1981. Seed banks in the soil. Advances in Applied Biology, Cambridge, Academic Press, Vol. 6, 55p.

Robichaud PR. 2000. "Fire Effects on Infiltration Rates after Prescribed Fire in Northern Rocky Mountain Forests, USA.” Journal of Hydrology 231(232):220-229.

Robichaud, P.R., Wagenbrenner, J.W., Brown, R.E., Wohlgemuth, P.M., and Beyers, J.L. 2008. "Evaluating the effectiveness of contour-felled log erosion barriers as a post-fire runoff and erosion mitigation treatment in the western United States.” International Journal of Wildland Fire $17: 255-273$.

Scott, J. H., and R. E. Burgan. 2005. Standard fire behavior fuel models: a comprehensive set for use with Rothermel's surface fire spread model. USDA Forest Service RMRS-GTR-153.

Smith DW. 1970. “Concentrations of soil nutrients before and after fire.” Can. J. Soil Sci. 50:17-29.

Steele RBD and JH Torrie. 1960. Principals and Procedures of Statistics. McGraw-Hill, New York.

Swift CE. 1997. "Salt Tolerance of Various Temperate Zone Ornamental Plants.” Available online at: http://www.colostate.edu/Depts/CoopExt/TRA/PLANTS/stable.html. Accessed 10/05/2009.

Tausch RJ, PE Wigand, and J. Wayne Burkhard. 1993. "Viewpoint: plant community thresholds, multiple steady states, and multiple successional pathways: legacy of the Quaternary?” Journal of Range Management 46(5):439-447.

Tiedemann, A.R., 1987. Nutrient accumulations in pinyon-juniper ecosystems - managing for future site productivity. In: Everett, R.L. (Ed.), Proceedings-Pinyon-Juniper Conference, compiler. USDA-FS, Intermountain. Gen. Tech. Rep. INT-215, Inter. For. and Range Res. Sta., Ogden, Utah, pp. 352-359.

USDA NRCS-U.S. Department of Agriculture/Natural Resources Conservation Service. 2009. The PLANTS Database, Baton Rouge, Louisiana, 70874-4490 USA, National Plant Data Center. Accessed online 10/05/2009 at: http://plants.usda.gov.

USGS Forest and Rangeland Ecosystem. David A. Pyke, 2002. "Born of Fire-Restoring Sagebrush Steppe.” Science Center, Corvallis, OR 97331 USGS FS-126-02

Wallis MG and DJ Horne. 1992. “Soil Water Repellency.” Advances in Soil Science 20:91-146.

Wan S, D Hui, and Y Luo. 2001. "Fire effects on nitrogen pools and dynamics in terrestrial ecosystems: a meta-analysis.” Ecological Applications 11:1349-1365.

Ward AL, GW Gee, and SO Link. 1997. Hanford Prototype Barrier Status Report: FY 1997. PNNL-11789, Pacific Northwest National Laboratory. Richland, Washington. 
Ward AL, ME Conrad, WD Daily, JB Fink, VL Freedman, GW Gee, GM Hoversten, JM Keller, EL Majer, CJ Murray, MD White, SB Yabusaki, and ZF Zhang. 2006. Vadose Zone Transport Field Study: Summary Report. PNNL-15443, Pacific Northwest National Laboratory. Richland, Washington.

Ward AL, GT Berlin, JW Cammann, KD Leary and SO Link. 2008. Test Plan to Assess Fire Effects on the Function of an Engineered Surface Barrier. PNNL-17859. Pacific Northwest National Laboratory, Richland, Washington.

Ward AL, KD Leary, SO Link, GT Berlin, JW Cammann, ML Mandis,and LC Beulow. 2009. "Short and Long-Term Fire Impacts on Hanford Barrier Performance.” PNNL-63665. Pacific Northwest National Laboratory, Richland, Washington.

Wentworth CK. 1922. “A Scale of Grade and Class Terms for Clastic Sediments.” Journal of Geology 30:377-392.

White MD and AL Ward. 2005. "Numerical Simulation of Surface Barriers for Shrub-Steppe Ecoregions.” Hydrology Days 25:224-236.

White EM, WW Thompson, and FR Gartner. 1973. "Heat effects on nutrient release from soils under ponderosa pine.” J. Range Manage. 26:22-24.

WSL 2003. Western States Laboratory Plant, Soil and Water Analysis Manual 2nd Edition, 2003; Printed versions of the complete manual can be obtained from Robert O. Miller

Youngberg CT. 1953. “Slash burning and soil organic matter maintenance.” J. For. 51:202-203. 


\section{Distribution}

\section{OFFSITE}

1 Belgian Nuclear Research Centre SCK•CEN Dirk Mallants

Boeretang 200

B-2400 MOL-Belgium

1 NIRAS/ONDRAF

Laurent Wouters

Kunstlaan 14

1210 Brussel

Belgium

1 Native Plant Landscaping \& Restoration Steve Link 4604 E. Robin Ct.

West Richand, WA 99353

ONSITE

3 DOE Richland Operations Office

Kevin Leary

A6-38

John Morse

A6-38

DOE Public Reading Room

$\mathrm{H} 2-53$

1 Environmental Protection Agency

Robin Paul

B1-46
7 CH2M-Hill Plateau Remediation Co. Inc. David Fort

Mark Benecke

T1-41

Greg Berlin

R3-60

Ronald Brunke

H8-15

James Butner

H8-15

William McMahon

H8-15

Curtis Wittreich

H5-81

H5-81

1 Washington River Protection Solutions

Jim Field

H6-03

2 Washington State Department of Ecology

Michelle Mandis H1-57

Asopuru Okemgbo H0-57

4 Pacific Nor thwest National Laboratory

Kate Draper K6-75

Nazmul Hasan K9-33

Andy Ward K9-33

Hanford Technical Library P8-55 



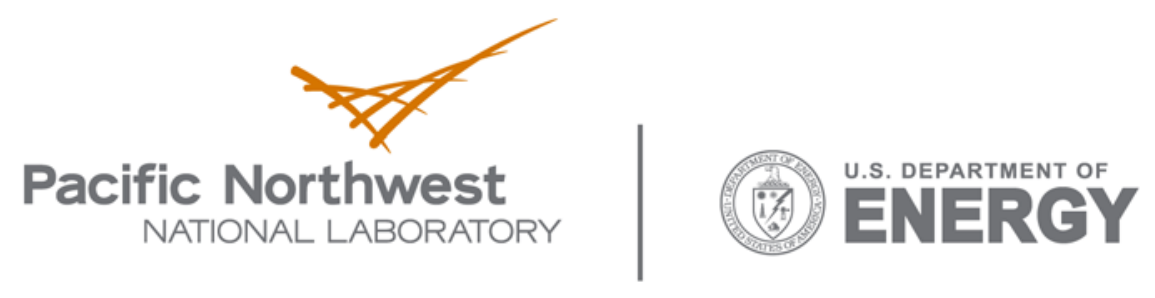

902 Battelle Boulevard

P.O. Box 999

Richland, WA 99352

1-888-375-PNNL (7665)

www.pnl.gov 